\title{
Caffeine Consumption through Coffee: Content in the Beverage, Metabolism, Health Benefits and Risks
}

\author{
Juliana dePaula and Adriana Farah *
}

Laboratório de Química e Bioatividade de Alimentos e Núcleo de Pesquisa em Café (NUPECAFÉ), Instituto de Nutrição, Universidade Federal do Rio de Janeiro, Avenida Carlos Chagas Filho, 373, CCS, B1.J, Rio de Janeiro 21941-902, Brazil; julianadepaula.nutricao@gmail.com

* Correspondence: afarah@nutricao.ufrj.br; Tel.: +55-21-30396449

Received: 14 February 2019; Accepted: 11 April 2019; Published: 1 June 2019

\begin{abstract}
Caffeine (1,3,7-trimethylxanthine) is the most consumed psychoactive substance in the world, acting by means of antagonism to adenosine receptors, mainly $\mathrm{A}_{1}$ and $\mathrm{A}_{2 \mathrm{~A}}$. Coffee is the main natural source of the alkaloid which is quite soluble and well extracted during the brew's preparation. After consumption, caffeine is almost completely absorbed and extensively metabolized in the liver by phase I (cytochrome P450) enzymes, mainly CYP1A2, which appears to be polymorphically distributed in human populations. Paraxanthine is the major caffeine metabolite in plasma, while methylated xanthines and methyluric acids are the main metabolites excreted in urine. In addition to stimulating the central nervous system, caffeine exerts positive effects in the body, often in association with other substances, contributing to prevention of several chronic diseases. The potential adverse effects of caffeine have also been extensively studied in animal species and in humans. These aspects will be approached in the present review.
\end{abstract}

Keywords: caffeine; coffee; consumption; metabolism; health benefits; potential adverse effects

\section{Introduction}

Caffeine consumption is an ancient habit. Different cultures discovered that chewing seeds, barks, or leaves of certain plants containing this substance had the effects of easing fatigue, increasing awareness, and elevating mood [1]. Caffeine (1,3,7-trimethylxanthine) is a heterocyclic organic compound with a purine base called xanthine, consisted of a pyrimidine ring linked to an imidazole ring [2] (Figure 1). Caffeine is known as an alkaloid because it is a secondary plant metabolite derived from purine nucleotides, with a heterocyclic nitrogen atom (definition of true alkaloid) [2,3]. However, because it does not have the incorporation of an amino acid in its biosynthesis [2], some authors call it a pseudo-alkaloid [4].<smiles>Cn1c(=O)c2c(ncn2C)n(C)c1=O</smiles>

Figure 1. Caffeine chemical structure.

Caffeine is the most abundant methylxanthine in foods [5]. It is present in nearly 100 species in 13 orders of the plant kingdom [6]. Although Coffea species are the major sources, it is also abundantly found in Camelia sinensis, maté (Ilex paraguariensis), coca (Erythroxylon coca) and Coffea leaves, in cocoa 
(Theobroma cacao) and guaraná (Pauliniacupana) seeds, and in kola (Cola sp.) nuts [2,7], in addition to other less significant sources. It is also found in several commercial non-alcoholic beverages, powders, capsules and in association with therapeutic drugs [5].

Although there are reports on the use of coffee at least since the 9th century, caffeine was only understood as a substance and component of food matrices in the middle of the 19th century. The compound was first isolated by the German researcher Ferdinand Runge (1795-1867), under the request of the chemistry and technology professor Johann Wolfgang Döbereiner (1780-1849) and the philosopher Wolfgang von Goethe (1749-1832) [8]. Caffeine was first called "kaffein", which later became "caffeine" in English and was included in the medical vocabulary in 1823 [9]. In the following years (1827 to 1865), the same compound was isolated from other plants with different names at times [10].

The chemical structure of caffeine was first proposed in 1875 by Ludwig Medicus (1847-1915), who, unusual for that time, deduced it from the already known pure compound [10]. The structures of caffeine and other methylxanthines were validated in 1882 by Hermann Emil Fischer (1852-1919), who published a series of studies on purine synthesis that were cited in his Nobel Prize in Chemistry in 1902. [11,12]. Since then, studies on caffeine have evolved largely, together with its broad consumption worldwide. Today, much is known about the compositional, metabolic and physiological aspects. This review will summarize these aspects, with a focus on contents in different beverages, health benefits and potential adverse effects associated with caffeine consumption through coffee.

\section{Chemical Aspects and Analysis of Caffeine}

Caffeine is colorless at room temperature, odorless, and bitter [13]. It dissolves well in boiling water, and its solubility is increased by the addition of acids and formation of complexes, such as benzoate, citrate, and salicylate, at high temperatures $\left(1 \%\right.$, w/v, at $15^{\circ} \mathrm{C}$ and $10 \%$ at $\left.60{ }^{\circ} \mathrm{C}\right)$ [14]. Better solubility is achieved in chloroform at room temperature [2]. In aqueous solution, at physiological $\mathrm{pH}$, caffeine is a non-ionized compound. The melting point is 234 to $239^{\circ} \mathrm{C}$ and the temperature of sublimation, at atmospheric pressure, is about 178 to $180^{\circ} \mathrm{C}$ [2]. Reports on caffeine ultraviolet (UV) absorption region differ slightly in the literature. A reasonable wavelength interval between 250-280 $\mathrm{nm}$ can be concluded from reports [2], although wavelengths from 243 to $302 \mathrm{~nm}$ have been used for analyses [15]. Maximum absorption ( $\lambda$ max) in aqueous solution occurs at 272/273 nm $[4,15,16]$.

Several analytical methods have been proposed for determination of caffeine in foods. Gravimetry was the first method developed for this analysis in food products [17]. However, it was time-consuming, and the poor cleaning procedure of the extract caused overestimation of the contents [18]. The absorption of electromagnetic radiation in the UV region by caffeine was described in the early 20th century [19]. A low-cost spectrophotometric analytical method based on the absorbance at $272 \mathrm{~nm}$ was developed in 1948 [20]. The method was faster, simpler and more accurate than gravimetric methods, but the results could still be overestimated by the presence of matrix interferents, usually associated with food products [18,21].

High-performance liquid chromatography (HPLC) technique was used in caffeine analysis for the first time in the early 1970s [22]. Ion exchange chromatography was also used to separate caffeine from other organic compounds in coffee at that time [23]. The use of HPLC for determination of caffeine was an important qualitative leap in terms of parameters of precision, accuracy, and speed [18], also allowing multi-analysis of methylxanthines. The development of stationary phases containing micro-particles $(5 \mu \mathrm{m})$ and the use of the gradient system to separate caffeine from other methylxanthines allowed better resolution in a shorter period of time [18]. However, in coffee matrix, due to the very low amount of other methylxanthines, HPLC and ultra-high-performance liquid chromatography (UPLC) isocratic systems have been often applied for determination and quantification of these compounds, using a reverse-phase column and a mixture of methanol and water as the mobile phase [24-26]. Methods for HPLC analysis evaluating simultaneously caffeine and additional compounds were developed in the 1980s [27]. In some cases, however, when only one methylxanthine is present in 
the matrix, UV-Vis spectrophotometric determination in clarified extracts may be preferred due to its low cost, fastness and reasonable accuracy and reproducibility when compared to chromatographic techniques [24]. With the development of UV/diode array detector (DAD), the multi-analysis of methylxanthines improved in terms of precision and accuracy, since each alkaloid was analyzed at its maximum absorption wavelength [28,29]. A UPLC/DAD method using a gradient of formic acid $0.1 \%$ and acetonitrile has been recently applied for simultaneous determination of methylxanthines and sugars [30]. Liquid chromatography-mass spectrometry (LC-MS) is one of the preferred techniques for determining caffeine at low levels and/or in very complex matrices. The three advantages of LC-MS over conventional HPLC methods can be represented by three " $\mathrm{S}$ ", sensitivity, selectivity and speed. Nonetheless, due to the high cost, LC-MS techniques are not economically justifiable for the analysis of caffeine in major sources of this compound, such as coffee [31].

In recent years, spectroscopy in the infra-red region has been introduced as a promising alternative technique to wet chemical methods [18,32], especially the Fourier transform infra-red spectroscopy (FTIR) [33]. Methods using this technique dissolve the active principles in chloroform, followed by filtration of the solution to remove the excipients [18]. Chemometrics is a valuable mathematical tool that, in combination with different chemical methods, enables the analysis of many variables in a single sample [18]. Principal components analysis (PCA) has been most commonly used among chemometric methods to discriminate samples with different chemical patterns. In the study by Briandet et al. [32], analyses of caffeine were performed by FTIR, followed by PCA, to discriminate Coffea arabica and Coffea canephora species among lyophilized dry instant coffee blends from Ireland.

More recently, bare carbon electrodes have been proposed as simple and efficient sensors for the quantification of caffeine in commercial beverages, presenting similar values when compared to results from UPLC analyses [30].

\section{Contents of Caffeine in Green Coffee Seeds}

The caffeine function in coffee plant and seeds seems to be basically related to protection. The "chemical defense theory" proposes that caffeine in young leaves, fruits, and flower buds acts to protect soft tissues from predators, such as insect larvae [34] and beetles [35]. The "allelopathic theory" proposes that caffeine in seed coats is released into the soil to inhibit the germination of other seeds $[4,36]$.

The genetic factor is the key determinant for caffeine content variation in green (raw) coffee seeds, especially between species and, to a lesser extent, varieties [37]. The effect of environment, agricultural practices, including the use of fertilizers, and post-harvest processing on methylxanthines contents seems to be less important than genetic aspects, except in the case of secondary processing, such as decaffeination [38-40]. The range of caffeine contents reported for green C. arabica L. vary in the literature between 0.7 and $1.7 \mathrm{~g} / 100 \mathrm{~g}$ (dry matter- $\mathrm{dm}$ ) [15,26,38,41-52], while those for $C$. canephora vary in the range between 1.4 and $3.3 \mathrm{~g} / 100 \mathrm{~g}(\mathrm{dm})[26,38,41,42,45,49,50,52-56]$. However, common values are in a narrower range, between 1.0 and $1.2 \mathrm{~g} / 100 \mathrm{~g}$, dw, for C. arabica [15,44,46-51,54], and between 1.7 and $2.1 \mathrm{~g} / 100 \mathrm{~g}(\mathrm{dm})$ for C. canephora $[26,39,43,51,55,56]$. In general, C. canephora seeds contain $40-70 \%$ more caffeine than $C$. arabica species $[57,58]$. C. arabica presents a more homogeneous composition independent of their geographical origin, due to the low genetic diversity characteristic of the species [41], while higher variability is observed in C. canephora seeds [55]. The lower caffeine content in C. arabica plants makes them more vulnerable to phytopathogens, as well as to biological and mechanical stress, than C. canephora plants [59]. Other methylxanthines have been identified in coffee seeds, but their contents are negligible, less than $1 \%$ of total methylxanthines [41].

Caffeine forms hydrophobically bound $\pi$-molecular complexes with chlorogenic acids, the main phenolic compounds in coffee, especially with 5-caffeoylquinic and 3,5-dicaffeoylquinic acids [60-63], in a 1:1 molecular ratio [64]. According to D'Amelio et al. [62,63], additional complexes may be formed in green coffee, but at lower rates, with caffeoylquinic acid precursors as well as other chlorogenic acid compounds, such as feruloylquinic acids, isomers of dicaffeoylquinic acid, and, during roasting, with 
chlorogenic acids lactones [65]. Such complexation in green seeds may be one of the facts responsible for the correlation observed between chlorogenic acids and caffeine contents within the subgenus Coffea [65]. These complexes seem to be also formed in the beverage (see Section 4: Contents of caffeine in roasted coffee seeds and brews).

Regarding post-harvest processing, after the fruits harvest, green coffee seeds are obtained by one of the different methods from which the most commonly known are called dry, wet and semi-dry processing $[57,66]$. Although all methods aim at removing the fruit flesh of coffee cherry, they do it in different ways, and this affects the final contents of some compounds in the seeds [67]. A few studies have compared the caffeine contents in seeds obtained by different post-harvest methods. They included comparisons between wet and dry methods [68], wet and semi-dry methods [48], and dry and semi-dry methods [69]. None of them observed a significant difference in caffeine results from the different methods.

Regarding the degree of maturation, small variation (about 2-10\%) in the content of caffeine in seeds have been observed during C. arabica fruits development [42,70]. After fruits development, significant changes have been observed among seeds from different maturation stages, with a decrease in contents observed as the fruits ripened and through senescence [44,71].

\section{Contents of Caffeine in Regular and Decaffeinated Roasted Coffee Seeds and in Brews}

\subsection{Caffeine in Roasted and Ground Coffee}

The content of caffeine is not significantly altered during coffee roasting due to its thermal stability, but small losses may occur owing to sublimation. In terms of percent composition, an increase in caffeine content may be observed due to the loss of thermolabile compounds [57]. The range of caffeine contents reported for roasted C. arabica seeds vary in the literature between 0.7 and $1.6 \mathrm{~g} / 100 \mathrm{~g}$ ( $\mathrm{dm})[4,15,26,29,50,70,72-74]$, while those for C. canephora vary in the range between 1.8 and $2.6 \mathrm{~g} / 100 \mathrm{~g}$ (dm) $[29,50,54,72]$.

\subsection{Caffeine in Soluble Coffee}

Soluble coffee production typically involves treating ground roasted coffee with hot water and high pressure to extract the water-soluble compounds, followed by drying. While in Western countries commercial ground roasted coffee generally consists of $C$. arabica seeds alone or of a blend with a small percentage of $C$. canephora seeds, in some Western countries, a high percentage of $C$. canephora or plain $C$. canephora may be designated for instant coffee production owing to the yield of higher amount of soluble solids in the brew. This explains the higher caffeine contents often observed in reconstituted soluble coffees purchased in some countries, such as Brazil, for example [57]. In C. canephora producing countries, such as Indonesia, for example, this species is also abundantly used for commercial ground roasted coffee.

Data from a few studies investigating the contents of caffeine in C. arabica and C. canephora seeds roasted in small scale laboratory roasters, as well as in commercial ground roasted blends and soluble coffees are presented in Table 1.

Table 1. Summary data from studies investigating the caffeine contents in roasted Coffea arabica, and Coffea canephora seeds, commercial blends and soluble coffees.

\begin{tabular}{|c|c|c|c|c|c|}
\hline $\begin{array}{c}\text { Coffee Species/Cultivar/ } \\
\text { Type }\end{array}$ & Country & $\mathbf{N}$ & $\begin{array}{c}\text { Range of Caffeine } \\
\text { Content } \\
(\mathrm{g} / 100 \mathrm{~g})\end{array}$ & $\begin{array}{l}\text { Mean Caffeine } \\
\text { Content } \\
(\mathrm{g} / 100 \mathrm{~g})\end{array}$ & Reference \\
\hline \multicolumn{6}{|c|}{ Coffea arabica } \\
\hline cv. Minas & USA & 2 & $0.9-1.2$ & 1.1 & [4] \\
\hline $\mathrm{Nr}$ & Ethiopia & 4 & $0.9-1.1$ & 1.0 & {$[15]^{*}$} \\
\hline $\mathrm{Nr}$ & $\begin{array}{c}\text { Hawaii, Colombia, Brazil, } \\
\text { Africa }\end{array}$ & 6 & $0.8-0.9$ & 0.8 & [26] \\
\hline $\mathrm{Nr}$ & $\begin{array}{l}\text { Brazil, Mexico, Colombia, } \\
\text { Guatemala }\end{array}$ & 9 & $1.2-1.6$ & 1.3 & [29] \\
\hline
\end{tabular}


Table 1. Cont.

\begin{tabular}{|c|c|c|c|c|c|}
\hline $\begin{array}{c}\text { Coffee Species/Cultivar/ } \\
\text { Type }\end{array}$ & Country & $\mathbf{N}$ & $\begin{array}{l}\text { ge of Caffeine } \\
\text { Content } \\
(\mathrm{g} / 100 \mathrm{~g})\end{array}$ & $\begin{array}{l}\text { Mean Caffeine } \\
\text { Content } \\
(\mathrm{g} / 100 \mathrm{~g})\end{array}$ & Reference \\
\hline $\mathrm{Nr}$ & Croatia & 6 & $0.8-1.4$ & 1.3 & [50] \\
\hline $\mathrm{Nr}$ & Brazil & 4 & $0.7-1.1$ & 0.9 & [70] \\
\hline $\mathrm{Nr}$ & Brazil & 3 & $1.2-1.3$ & 1.3 & [72] \\
\hline $\mathrm{Nr}$ & Poland & 2 & $1.0-1.1$ & 1.0 & [73] \\
\hline cv. Bourbon, Catuaí, Icatu & Brazil & 3 & $1.0-1.3$ & 1.2 & [74] \\
\hline \multicolumn{6}{|c|}{ Coffea canephora } \\
\hline cv. Robusta & $\begin{array}{l}\text { India, Honduras, Vietnam, } \\
\text { Angola, Caneron }\end{array}$ & 20 & $2.0-2.6$ & 2.3 & [29] \\
\hline cv. Robusta & Croatia & 2 & $1.8-2.5$ & 2.2 & [50] \\
\hline cv. Robusta & Ivory Coast & 1 & - & 2.0 & [54] \\
\hline- & Brazil & 3 & $2.2-2.3$ & 2.2 & [72] \\
\hline \multicolumn{6}{|c|}{ Commercial blends of $C$. arabica or $C$. arabica and C. canephora (cv Robusta or cv. Conilon) } \\
\hline Arabica blends & USA & 36 & $0.8-1.4$ & 1.2 & [4] \\
\hline Blend & Africa & 1 & - & 1.4 & [26] \\
\hline Blends & Brazil & 10 & $0.8-1.4$ & $\mathrm{Nr}$ & [75] \\
\hline Blends & USA & 6 & $1.0-1.6$ & 1.3 & [76] \\
\hline $\mathrm{Nr}$ & $\mathrm{Nr}$ & 3 & $1.4-1.9$ & 1.7 & [77] \\
\hline Blends & Brazil & 40 & $0.8-1.6$ & 1.2 & [78] \\
\hline- & Mexico & 3 & $1.5-1.7$ & 1.5 & [79] \\
\hline \multicolumn{6}{|c|}{ Soluble coffee } \\
\hline $\mathrm{Nr}$ & Brazil & 2 & $2.0-2.2$ & 2.1 & [26] \\
\hline $\mathrm{Nr}$ & $\mathrm{Nr}$ & 2 & $4.5-4.8$ & $\mathrm{Nr}$ & [77] \\
\hline Blends & Brazil & 10 & $1.8-3.1$ & 2.5 & [78] \\
\hline Arabica & Brazil & 3 & $2.8-4.1$ & 3.4 & [80] \\
\hline cv. Conilon & Brazil & 3 & $3.9-5.8$ & 5.0 & [80] \\
\hline $\mathrm{Nr}$ & Brazil & 9 & $1.6-3.2$ & 2.5 & [81] \\
\hline $\mathrm{Nr}$ & Kenya & 2 & $1.6-3.4$ & 2.7 & [82] \\
\hline $\mathrm{Nr}$ & $\mathrm{Nr}$ & 5 & $2.2-3.9$ & 2.8 & [83] \\
\hline
\end{tabular}

Note: N: number of samples, Nr: not reported. Analyses performed by liquid chromatography unless specified by * which indicates analysis performed by UV/vis spectrophotometer.

\subsection{Caffeine in Coffee Brew}

Caffeine content in coffee brew is closely related to its stimulating properties as well as to about $10 \%$ or less of its bitterness $[39,47]$. The final content of caffeine ingested by coffee drinkers depends on all factors that affect the seeds contents, including blend composition, which depends mainly on genetics, the degree of maturation, and the method used to brew the coffee, which may vary considerably according to social and cultural habits of each country [57]. Caffeine is well extracted by the most common hot brewing methods [57]. Percolation and decoction methods tend to extract more than infusion methods which have low extraction power [58], but not only the extraction method is important. The proportion of water to powder, water temperature, size of particle and duration of the brewing process are determinant factors $[57,76]$. Caffeine seems also to be more easily extracted from dark roasted coffees, and the type of filter may alter the result [84]. Lastly, there is the variability within the preparation method, which may be very low or quite high in the case of commercial establishments with different people preparing the brews. In a study that analyzed caffeine content in 20 different specialty coffees purchased at coffee shops in the United States, the amount of caffeine in brews ranged from 76 to $112 \mathrm{mg} / 240 \mathrm{~mL}$ serving (equivalent to 32 to $47 \mathrm{mg} / 100 \mathrm{~mL}$ ) [85]. It was also observed that caffeine content in the same type of coffee purchased in the same store on six separate occasions ranged from 130 to $282 \mathrm{mg} / 240 \mathrm{~mL}$ serving (equivalent to 54 to $118 \mathrm{mg} / 100 \mathrm{~mL}$ ) [85]. Data from studies investigating the contents of caffeine in coffee beverages prepared by different methods are presented in Table 2. Average values for the most commonly used methods are presented in Figure 2. 
Table 2. Caffeine contents in coffee brews obtained by different extraction methods.

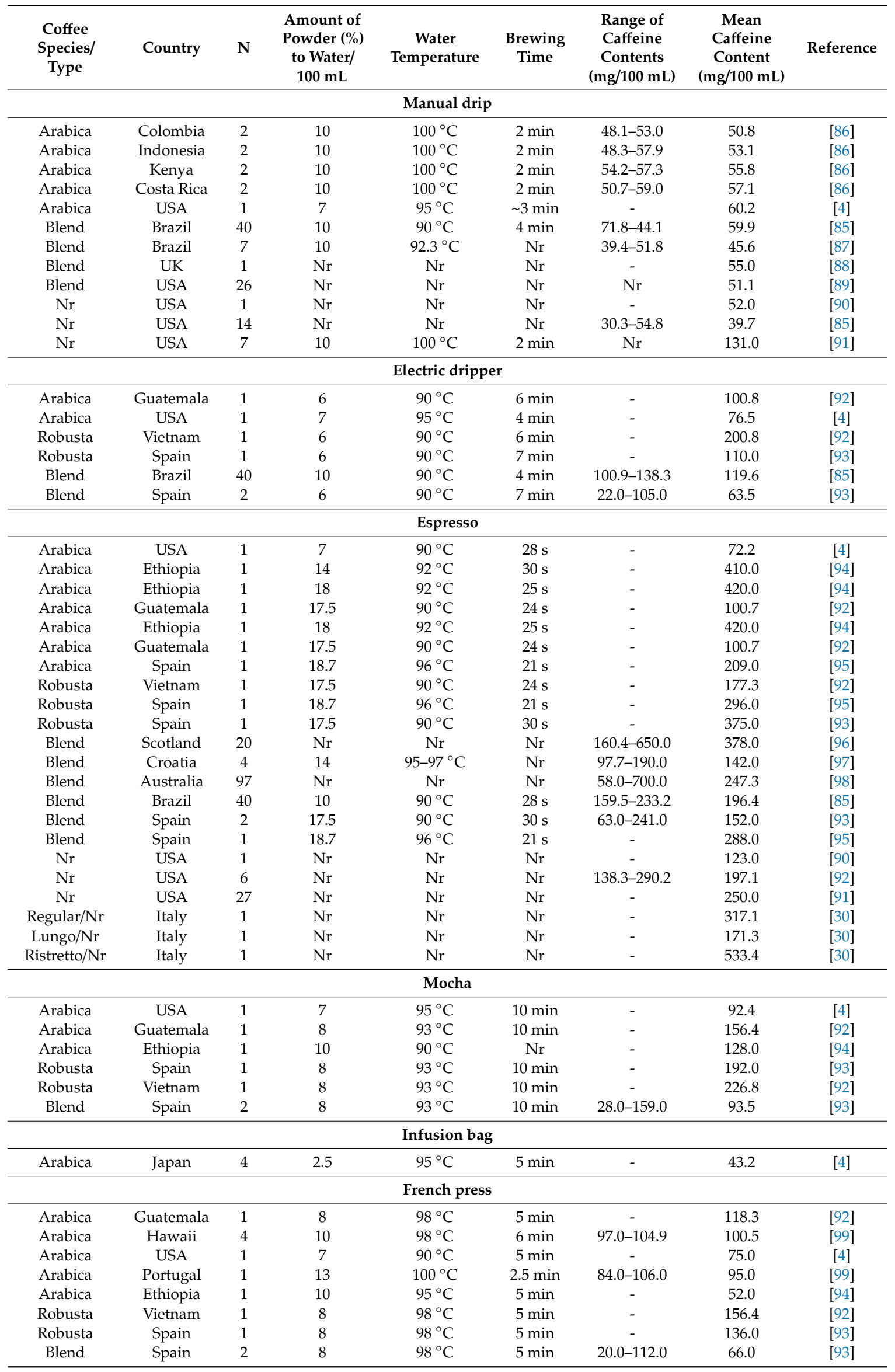


Table 2. Cont.

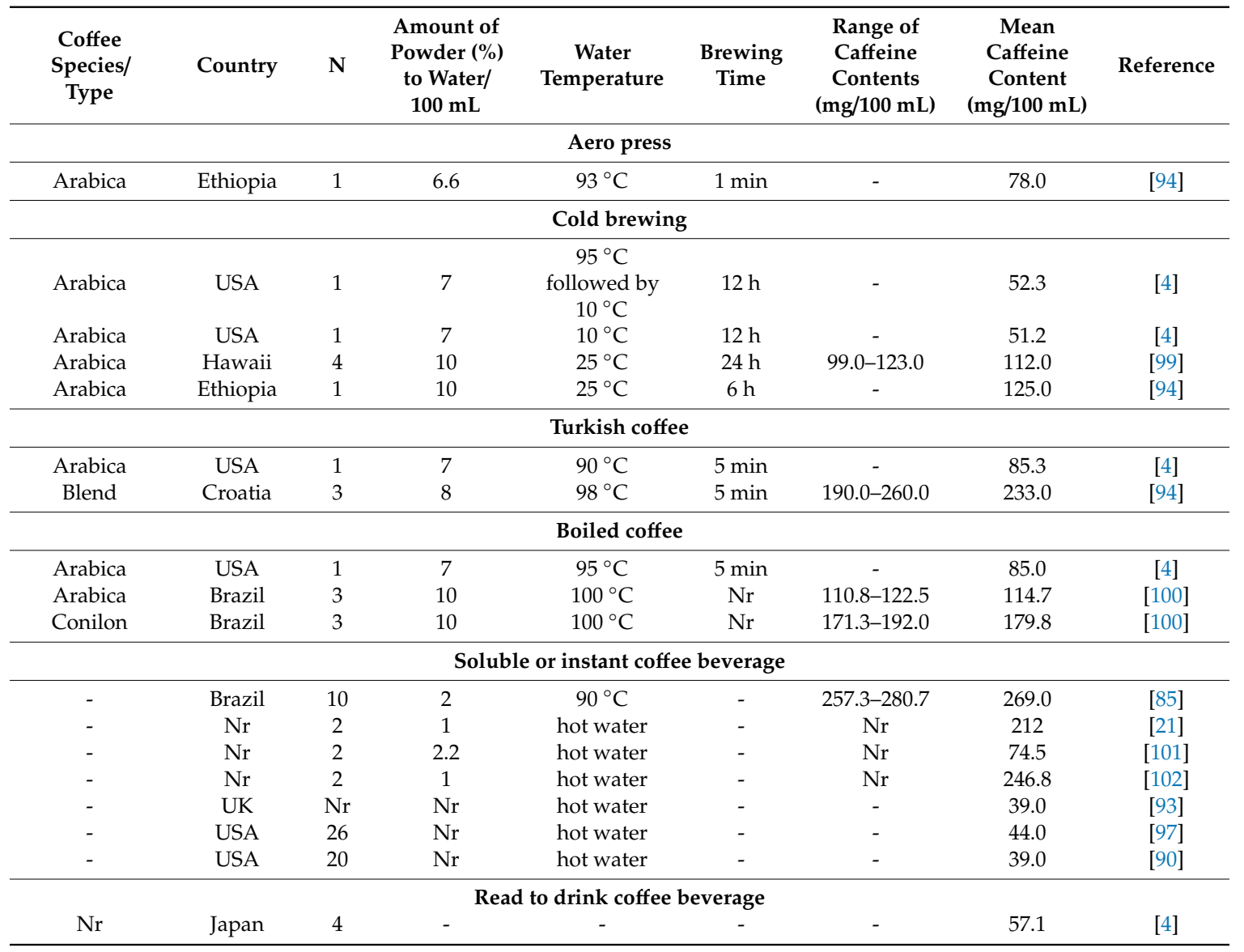

Note: N: number of samples. Nr: Not reported.

Figure 2 illustrates the caffeine content variability among brews obtained by different preparation methods as well as the variability within each method. The reasons for such values are already aforementioned. Mostly, in addition to the characteristic power of extraction of the methods, which have been comparatively consistent in literature reports [78,84], the amount of coffee to water and grid also vary traditionally among them. It is important to note that these values are given per $100 \mathrm{~mL}$ and, in order to compare the consumption per serving, one has to consider the various existing sizes of cups used for the different types of coffees and cultures. Usually, however, the more concentrated the brew, the smaller the cup is. This explains the large servings of infusions of manually dripped coffees $(236.5-591.4 \mathrm{~mL} / 8-20 \mathrm{oz})$ in the USA, in comparison with $15-30 \mathrm{~mL}$ of a ristretto in Italy.

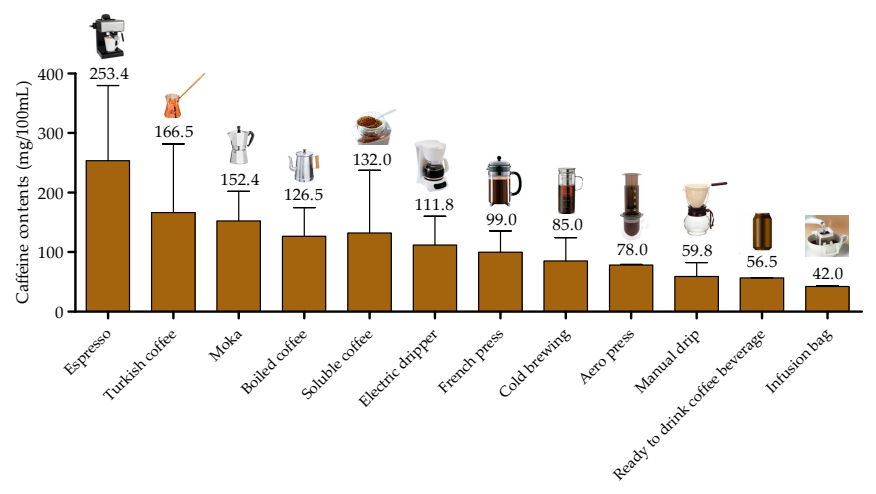

Figure 2. Mean reported caffeine contents $(\mathrm{mg} / 100 \mathrm{~mL})$ in coffee brews obtained from a variety of blends, and by different preparation methods (values extracted from Table 2). 


\subsection{Caffeine Complexation with Chlorogenic Acids}

It has been reported $[62,63]$ that in addition to the free caffeine content presented in Table 2 and Figure 2, there are also some complexes formed between caffeine and other compounds. According to estimates based on results from model complexation with pure compounds and from espresso beverage analysis $[62,63]$, about $20 \%$ of total caffeine in the beverage (considering free and bound caffeine) forms a complex with 5-caffeoylquinic acid (the main chlorogenic acid in coffee) and, to a lesser extent, with other major chlorogenic acids and lactones, the latest formed during roasting process. Structurally explaining, it was proposed, using a model in aqueous solution, that in the case of complexation with 5-caffeoylquinic acid, and probably also feruloylquinic acid and lactones, the plane of caffeine molecule would be parallel to the plane of the aromatic ring of the caffeoyl ester group and that the five and six-membered rings of the nitrogen heterocycle would be equally involved in the complex formation. In the case of 3,5-dicaffeoylquinic acid, a sandwich structure (caffeine between two caffeoyl arms) was proposed. For other dicaffeoylquinic acids with lower chances of complexation, other forms of complexations were proposed. In addition to forming complexes with chlorogenic acids, according to the authors, about $10 \%$ of caffeine could be bound to other types of substances, such as proteins and, after roasting, to melanoidins. For structures and other information on chlorogenic acids, please see reference [103].

\subsection{Caffeine in Decaffeinated Coffee}

Coffee decaffeination is performed in the green seeds but given that recommendations for residual content are made for roasted coffee, we chose to present this subject here. The first method for this purpose was developed in Europe, but decaffeinated coffee achieved its first broad market in the United States during the 1950s [104]. Since the early 1970s, the demand for decaffeinated coffee has also gradually increased worldwide. World consumption of this type of coffee is difficult to gauge owing to the lack of separate statistical data for many importing countries. According to the latest Coffee Drinking Study performed by the National Coffee Association (USA), the consumption of decaffeinated coffee in 2009 reached $16 \%$ of total coffee consumption [104]. Current information on decaffeinated coffee sales in the US is not available in common coffee market reports. Elsewhere, consumption of decaffeinated coffee has been fairly static over the last two decades and currently accounts for approximately $12 \%$ of total worldwide coffee consumption [105], although in many countries new low-caffeine coffee products have been introduced [106].

The decaffeination process can be performed using different methods and extraction vehicles (water, supercritical carbon dioxide, ethyl acetate, methanol chloride) and often leaves residual amounts of caffeine in the seeds [57]. According to various national and international rules and regulations, decaffeination processes should lower the methylxanthine concentration by $97-99.9 \%$ in ground roasted coffee and $97 \%$ in instant coffee [107-109], with no significant influence on other natural compounds [58]. A more restricted norm is mandatory in the European Community countries, in which decaffeinated coffee must be $99.9 \%$ alkaloid-free $[58,107]$.

About $0.3-0.5 \mathrm{mg}$ caffeine/100 g have been reported in decaffeinated ground roasted coffees [76] and $0.7-0.9 \mathrm{mg} / 100 \mathrm{~g}$ in instant decaffeinated coffees [77]. Regarding decaffeinated coffee brews, caffeine values from 0.1 to $2.6 \mathrm{mg} / 100 \mathrm{~mL}$ have been reported for brews made from decaffeinated ground roasted coffees purchased in Brazil and in the United Kingdom [24,88], while in decaffeinated coffee brews purchased in the United States coffee shops caffeine content reached $18 \mathrm{mg} / 473 \mathrm{~mL}$ serving $(\sim 3.7 \mathrm{mg} / 100 \mathrm{~mL})$ [92]. Contents from 0.9 to $1.2 \mathrm{mg} / 100 \mathrm{~mL}$ have been reported for reconstituted instant decaffeinated coffee $[21,24,88]$. It is noteworthy mentioning that, for a heavy coffee drinker, the ingestion of multiple servings of decaffeinated beverages could result in caffeine doses equivalent to a caffeinated beverage [110]. 


\section{Global Caffeine Consumption Through Coffee}

Currently, approximately $80 \%$ of the world's population consumes a caffeinated product every day [111], mainly for its stimulating effects, which makes it the most widely consumed psychoactive substance in the world [112-116]. So where does coffee consumption stand in relation to other caffeine sources? Over the last 50 years, world coffee consumption increased at a mean annual growth rate of $1.9 \%$, to almost 9.7 million tons in 2018 [117]. The highest coffee consumption occurs especially in the Americas, Europe and Japan [117]. The European Union is responsible for the largest consumption volume (about $28 \%$ of the total world consumption), but breaking up into individual countries, the USA are the first consumer country (about $16 \%$ of the total world consumption), followed by Brazil (the largest producer, with $13 \%$ of world consumption), European Union countries, and Japan. Philippines, Russia, Ethiopia, Canada and Mexico contribute about $2.8 \%, 2.5 \%, 2.4 \%, 2.3 \%$ and $1.5 \%$ of total world consumption, respectively [117]. In Canada (6.5 kg/year coffee per capita consumption), as well as in many European countries, such as Denmark ( $8.7 \mathrm{~kg} /$ year), Norway $(9.9 \mathrm{~kg} /$ year) and Finland (12 kg/year), coffee consumption is very prevalent and accounts for most of the daily caffeine consumption among adults [118].

Considering these data, it is not difficult to accept that coffee is the major contributor to caffeine intake in most countries worldwide. Exceptions occur in specific areas, such as regions of South America [119,120], Ireland and the United Kingdom, China, India and other Asian countries [121], where other beverages, such as maté leaves, natural guaraná beverage, and black/green Camelia sinensis teas, are typically consumed.

However, additional sources of caffeine and other methylxanthines, mainly theobromine, are also consumed worldwide and, for this reason, over the past years, there has been a renewed interest in understanding caffeine exposure in populations. The daily caffeine intake and the type of caffeinated product consumed vary considerably around the world, with sex, age segments, cultural habits and household income. The age interval considered for each category also varies among studies and reviews. The cultural habits influence not only the total intake but also the percent contribution of foods to such intake. Differences also occur among geographic regions and between metropolis and countryside, where certain types of products are not available. Other than cultural habits, one reason for the differences in consumption levels is the variable concentrations of caffeine found among home-made beverages [122].

Regardless of the longstanding consumption of caffeine-containing beverages in the diet and acknowledging all the aforementioned aspects, there is a lack of current and comprehensive population-based data on caffeine intake. Most studies on intake still cite information dating back the 1980s and 1990s, when Barone and Roberts [90] highlighted results from earlier population-based surveys or data from the food balance sheets published by the Food and Agriculture Organization (FAO) of the United Nations in 1995 [123], which contains average food consumption estimates in all world countries for all genders and ages. However, the national consumption of caffeine summarized in the food balance sheets depended heavily on official statistics, which were thought to be greatly unreliable at that time [111]. In addition, the estimates did not include soft drinks, although they may be a major source of caffeine for children and adolescents, especially in Western society $[90,111,121,124]$. As a result, the intake was underestimated. More recently, in a survey performed in 2015 by Mitchell et al. [125], including 37,602 interviews in the United States, adults consumed, on average, $152 \mathrm{mg}$ of caffeine/day and the elderly $207.3 \mathrm{mg}$ of caffeine/day. Less was consumed by adolescents ( $83 \mathrm{mg} / \mathrm{day})$ and children (30 mg/day). Due to the high consumption of regular soft drinks, they accounted for the main source of caffeine among children and adolescents, while coffee was the main source of caffeine consumption in adults. This was also observed in an earlier study performed by the same authors in 2014 [124]. According to Mitchell et al. [125], the American population, considering all ages, consumes $164.5 \mathrm{mg}$ caffeine/day, with coffee being responsible for $64 \%$ of this amount. Considering only adults and the elderly, the coffee contribution was reported to be $63 \%$ and $76 \%$, respectively. 
Further, in 2015, the Comprehensive European Food Consumption Database organized by the European Food Safety Authority (EFSA) [126] was used for the calculation of caffeine intake from all sources. It contains data from 39 surveys in 22 different European countries for a total of 66,531 participants. In most European surveys covered by EFSA's Food Consumption Database [126], coffee was the predominant source of caffeine for adults and the elderly, contributing, on average (considering all countries), $78 \%$ and $84 \%$ of total caffeine intake, respectively. Exceptions were Ireland and the United Kingdom, where tea was the main caffeine source. The average caffeine consumption by adults in the UK was reported to be $138 \mathrm{mg} /$ day for adults and $165 \mathrm{mg} /$ day for the elderly, with the coffee contribution of only $34 \%$ and $33 \%$, respectively. Nordic countries were among the largest consumers. The reported intakes by adults in Denmark, Finland, and Sweden were 320, 236, and $205 \mathrm{mg} /$ day for adults, and 362, 214, and $222 \mathrm{mg} /$ day for the elderly, respectively, with coffee contributions of $88 \%, 94 \%$ and $85 \%$ for adults and $91 \%, 97 \%$ and $89 \%$ for the elderly, respectively.

There is no official data on caffeine consumption in Latin American countries [127]. However, it is believed that caffeine intake in countries, such as Brazil and Argentina, are high due to the large popular intake of coffee and mate tea. A similar situation may occur in China due to the high intake of green tea [127]. Recently, in Brazil, caffeine consumption was estimated [128] based on 13,569 interviews by the national consumption survey (Consumer Expenditure Survey, 2008-2009) performed by the Brazilian Institute of Geography and Statistics. The average daily caffeine intake by Brazilians of all genders, age groups, geographic locations, and income classes was, on average, about $130 \mathrm{mg} /$ day, with coffee being responsible for $90 \%$ of daily caffeine intake. Considering adults and the elderly, total intakes were, on average, 137 and $146 \mathrm{mg} /$ day respectively, with coffee contributions of $90 \%$ and $95 \%$, respectively.

Regarding pregnant or lactating women, studies that evaluated the available data on daily caffeine intake among these groups are very scarce [118]. Using data collected in the United States by Share of Intake Panel for pregnant women, Knight et al. [129] estimated in 2004 the average daily caffeine consumption from beverages in about $58 \mathrm{mg}$ /day. Later, in 2009, using data from interviews, Olmos et al. [130] estimated daily caffeine consumption among Argentinean pregnant women in approximately $200 \mathrm{mg} /$ day.

\section{Caffeine Metabolism}

The first studies on coffee bioactivity in humans date back centuries ago. Coffee was present in medical journals since the 18th century, and the early physiological explanations already emphasized nervous and vasomotor stimulation [131]. Caffeine is involved in several biological effects in the human body, most of them related to improvements in brain and Central Nervous System (CNS) functions. However, the biological effects associated with caffeine consumption largely depend on its biotransformation in the body [132]. The earliest reported study on caffeine metabolism seems to have been carried out in 1850 by Lehmann, who, following an oral dose, failed to detect traces of caffeine in human urine. This was even before the chemical characterization of the compound by Hermann Emil Fischer (1852-1919) in 1882 [114]. Albanese, in 1895 was the first to report that dogs and rabbits fed large doses of caffeine excreted a monomethylxanthine, showing that ingested methylxanthines were demethylated. A few months later, Rost published data on the excretion of unchanged caffeine and theobromine in a cat, a dog, a rabbit, and a man [114]. The most complete pharmacokinetic studies on caffeine in human subjects as well as various experimental animals started to be performed late in the 1950s [133-137]. Other studies in humans followed including minor methylxanthines, accessing their primary metabolites in plasma [138-141] or in urine [141-143]. Paraxanthine, 1-methylxanthine, and 1-methyluric acid have been the first urinary metabolites of caffeine identified in men and rabbits [133]. Subsequently, theobromine and theophylline were also reported to be urinary metabolites of caffeine in men and dogs [135,144]. Later, improved analytical methodologies confirmed the extensive metabolization of caffeine, identifying secondary metabolites such monomethylxanthines (1-methylxanthine and 7-methylxanthine), and methyluric 
acids (1-methyluric acid and 1,7-dimethyluric acid) in both plasma [145-148] and urine [148,149]. However, the most important results obtained in earlier studies have been ratified by recent studies.

\subsection{Absorption}

The pharmacokinetics of caffeine is relatively well elucidated and has been reported in several studies, including recent ones $[114,146,148,149]$. Most existing reports on the matter come from studies using pure caffeine in the form of solutions, capsules, and tablets [138,140,150,151]. Among the food matrices evaluated, the most common are coffee, cola, and cocoa products [114,131,140,141,146-148]. The bioavailability of caffeine is similar among dogs, rats, and mice [114,152]. Because no hepatic first-pass effect complicates its pharmacokinetics, caffeine absorption from foods and beverages has been shown to be independent of the administration route, age, sex, health status, and concomitant administration of alcohol, drugs and nicotine exposure [58,114,132].

Following ingestion, caffeine is rapidly and almost completely (up to 99\%) absorbed into the bloodstream. About $20 \%$ absorption occurs in the stomach, and the remaining $80 \%$, in the small intestine [114,138]. Caffeine can also be quickly absorbed through the oral mucosa [153], as it does not need to pass the stomach and intestine to get into the blood [153-156], and when administered via enema [146]. The pharmacokinetics of a similar dose of caffeine after a single administration of a coffee enema $(107.2 \pm 2.2 \mathrm{mg})$ versus coffee consumed orally $(96.3 \pm 1.3 \mathrm{mg})$ was compared in healthy male subjects $(n=11)$. The relative bioavailability of caffeine obtained from the coffee enema was about 3.5 times lower than when coffee was consumed orally [132,146].

In different studies, the time to reach the peak plasma concentration $\left(T_{\max }\right)$ after oral doses of 72 to $375 \mathrm{mg}$ of caffeine in healthy adult volunteers has most often varied between 15 and $60 \mathrm{~min}[138,140,142,147,155,156]$, but, in some circumstances, it has taken $120 \mathrm{~min}$ after oral intake, mainly due to delayed gastric emptying $[153,157,158]$. This involves motility of gastrointestinal tract, individual physiology, and vehicle (the type of food matrix, volume, solid or liquid, capsule, gum) $[112,159]$. In studies using different food matrices, the absorption of caffeine from soda and chocolate was slightly delayed, relative to coffee [112,140,159], caffeine in a chewing gum format was absorbed faster than in coffee [153] or in capsules [154] and in capsules, the absorption of the same caffeine dose was faster than in coffee [112,140].

After oral consumption of $70-500 \mathrm{mg}$ of caffeine, peak plasma concentration $\left(C_{\max }\right)$ varies in reports between 1.1 to $17.3 \mu \mathrm{g} / \mathrm{mL}[114,138,140,141,145,147,148,155]$. Because caffeine is usually ingested in a daily diet, owing to accumulation, its actual plasma concentration may be more than the value reported in single-dosage studies, which are usually preceded by wash out or clearance period [58,132].

\subsection{Metabolism and Distribution}

After absorption, caffeine is quickly distributed to most tissues (mean volume distribution of 0.6-1.0 L/kg) and body fluids (i.e., bile, milk, saliva, semen, sweat, and urine) [114], although it is received in the body as a xenobiotic substance. Studies have reported that concentrations of caffeine in saliva are approximately $20-40 \%$ lower than in plasma [145,160-163]. The limited plasma protein binding (estimated at $17-30 \%$ ) combined with the relatively hydrophobic properties of caffeine allow its passage through all biological membranes $[14,114]$ and enables it to easily cross intracellular barriers, including placental (mother-fetus-mother) and blood-brain barriers [114,132]. The distribution pattern usually does not change during a person's entire life, and it can be significantly higher in women when compared to men $[164,165]$. However, severely obese subjects have exhibited an increased volume of distribution [165,166], although this volume was decreased with weight reduction [114]. The effect was more important in females, and it was suggested that caffeine distribution into the adipose tissue was incomplete, representing 70-80\% excess of body weight in obese subjects [164]. Caffeine and its major metabolite paraxanthine can be found in the amniotic fluid throughout gestation [167], and they are distributed to fluids and tissues of the fetus [167]. Caffeine has also been identified in women's milk $[133,168]$. 
Caffeine is rapidly and extensively metabolized in the liver cells to form dimethyl and monomethylxanthines, dimethyl and monomethyluric acids, and uracil derivatives [114]. Most of the metabolism of caffeine and other methylxanthines is performed by phase I (cytochrome P450 CYP) enzymes, mainly CYP1A2, a major enzyme, among P450 enzymes in the human liver, that accounts for approximately $13 \%$ of the total content of this enzyme group. The activity of the CYP1A2 isoform accounts for almost $90 \%$ of caffeine metabolism $[114,143,169]$. The remaining pathways are related to CYP1A1, CYP2E1, CYP2A6, as well as mono-oxygenase and N-acetyltransferase activities $[58,132]$.

Paraxanthine is the major caffeine metabolite in plasma, while methylated xanthines and methyluric acids are the main metabolites excreted in urine $[114,148]$. The metabolic pathway of caffeine in humans is shown in Figure 3. From the metabolic pathways of caffeine, it is apparent that each metabolite may be derived from more than one precursor [139].

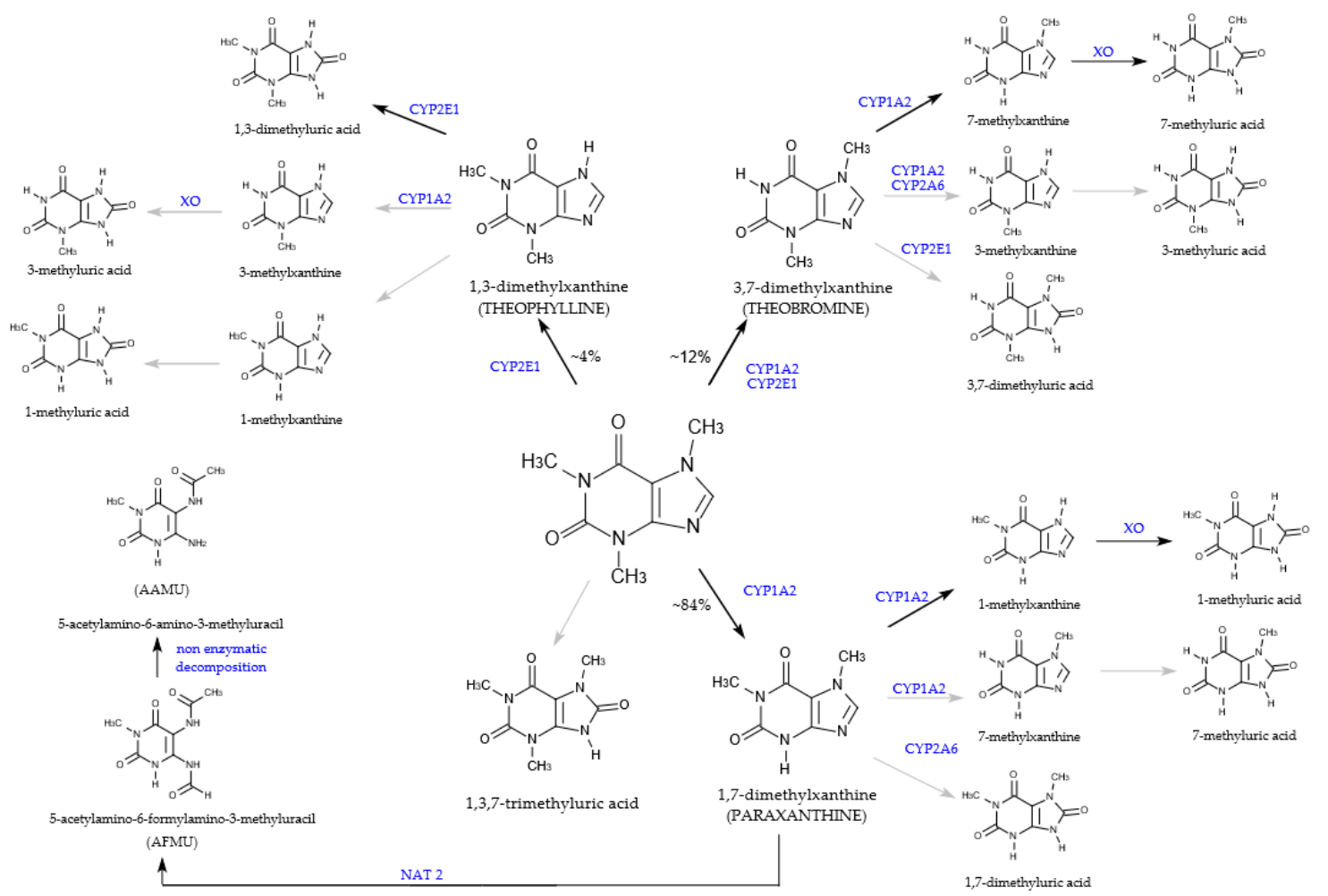

Figure 3. Metabolic pathways of caffeine and metabolites in humans. Grey arrows indicate lower production of the metabolite. Adapted from [132]. XO: xanthine oxidase, NAT 2: N-acetyltransferase 2.

The initial metabolization by CYP1A2, begins with 3-demethylation of caffeine, resulting in the formation of 1,7-dimethylxanthine (paraxanthine), which represents about $84 \%$ of primary caffeine metabolites $[143,170]$ (Figure 3). CYP1A2 enzyme may also convert caffeine to theobromine $(\sim 12 \%)$ [171]. CYP2E1 participates in the metabolism of caffeine accelerating the synthesis of theobromine and theophylline $(\sim 4 \%)$ by 7 - and 1-demethylation [58]. In a lesser extent, caffeine may be converted to 1,3,7-methyluric acid [132]. Paraxanthine, the major primary caffeine metabolite may be demethylated by CYP1A2 to form the main metabolite, 1-methylxanthine ( 70\%), which may be oxidized to 1-methyluric acid by xanthine oxidase. Secondary metabolites, such as 7-methylxanthine ( $20 \%$ ) may also be oxidized to 7-methyluric acid [58,114], and paraxanthine may also be hydroxylated by CYP2A6 to form 1,7-dimethyluric acid or acetylated by $\mathrm{N}$-acetyltransferase 2 , to form 5-acetylamino-6-formylamino-3-methyluracil, an unstable compound that may be non-enzymatically deformylated to form 5-acetylamino-6-amino-3-methyluracil [14,132,172] (Figure 3). 
The pharmacological and biochemical properties of caffeine make it a model substrate capable of revealing activity of other drug metabolizing enzymes in animals and humans $[173,174]$. Caffeine has been extensively used as a probe to assess the metabolic activity and phenotyping of CYP1A2, CYP2A6, $\mathrm{N}$-acetyltransferase 2 and xanthine oxidase enzymes activities, providing valuable information on cancer susceptibility, drug interactions and toxicity in population studies of healthy subjects, given that these are important detoxifying enzymes [175]. For example, the ratio of paraxanthine to caffeine, or the ratio of paraxanthine plus 1,7 dimethyluric acid to caffeine in plasma has been used as an indicator of CYP1A2 activity $[58,176,177]$.

The half-life of caffeine in plasma seems to vary, on average, between $2.5-5 \mathrm{~h}$ in adults [14], although larger variations from 2.3 to $12 \mathrm{~h}$ have been reported [156], indicating substantial intersubject variability in caffeine elimination time [138]. Caffeine's half-life is altered in the neonatal period. It increases shortly after birth due to lower activity of cytochrome P-450 enzymes and the relative immaturity of some demethylation and acetylation pathways [178]. Caffeine's half-life is about $80 \mathrm{~h}$ for the full-term newborn infant and can be over $100 \mathrm{~h}$ in premature infants [179]. Infants up to the age of eight to nine months still present a reduced ability to metabolize caffeine, excreting in urine about $85 \%$ of the administered caffeine in its unchanged form [180]. Moreover, caffeine's half-life may be influenced by other factors, including sex, smoking habit, use of oral contraceptives, and specific biological moments, such as pregnancy [14,114]. Caffeine's half-life has been reported to be $20-30 \%$ shorter in females than in males [178] and 30 to $50 \%$ shorter in smokers compared to nonsmokers' adult males [181]. On the other hand, caffeine's half-life is almost doubled in women taking oral contraceptives $[182,183]$ and greatly prolonged (up to $15 \mathrm{~h}$ ) during the last trimester of pregnancy [184] and in patients with liver diseases [14]. In fact, health status, in general, is another factor that influences caffeine metabolism. The biotransformation is related to the proper function of the liver and kidneys, and the decrease of caffeine plasma clearance is a typical complication of these organ's diseases [132]. Cirrhosis and non-cirrhotic cases of viral hepatitis are the most common liver diseases that may disturb such process [58]. Obesity significantly increases plasma half-life, and decreases elimination rate, without significant effect on the clearance [132].

The consumption of high amounts could lead to saturation in caffeine metabolism [148]. Thus, while linear pharmacokinetics have been observed with caffeine intake between 70 and $100 \mathrm{mg}$, doses ranging between 250 and $500 \mathrm{mg}$ have resulted in increased plasma concentration, a non-linear kinetic and prolonged half-life [148,154].

Regarding the interindividual variability in caffeine metabolization speed, the activity of CYP enzymes has been reported to vary between individuals up to 50-fold for some metabolic reactions [185]. The large interindividual variability of CYP1A2 activity may be due to factors, such as gender, race, genetic polymorphisms, and environmental influences, such as smoking or exposure to chemicals $[186,187]$. For example, higher activity of CYP1A2 has been shown in men compared to women $[169,177,188-190]$ and in white compared to black subjects [191]. The enzyme activity is increased by cigarette smoking [192], and by moderate daily coffee consumption (at least three cups of coffee). Some studies have reported that herbal medicines can induce or inhibit human CYP1A2 activity [193-196]. During pregnancy, the excretion of 1-methylxanthine and 1-methyluric acid was decreased in women of between 34-36 gestational weeks that consumed caffeine doses from 123 to $369 \mathrm{mg}$ [197], owing to a decrease in CYP1A2, xanthine oxidase, and acetyltransferase activities [198]. CYP1A2 is also inhibited by oral contraceptives [186].

CYP1A2 appears to be polymorphically distributed in human populations. The CYP1A2*1F polymorphism characterizes the so-called "slow metabolizer" phenotype, which decreases enzyme activity and inducibility and allows caffeine to stay longer bioavailable [192]. Conversely, homozygous individuals (AA) for the allele CYP1A2*1A are rapid caffeine metabolizers. These individuals present lower caffeine plasma levels and shorter exposure to this compound [192]. On the other hand, homozygous individuals (CC genotypes) have been considered as "slow metabolizer" [199,200]. Such polymorphism was observed in 1999 by Sachse et al. [192]. They first sequenced intron 1 of the 
CYP1A2 gene in DNA from eight volunteers and observed only one polymorphism represented by an Adenine $\rightarrow$ Cytosine $(A \rightarrow C)$ substitution at position $734(C Y P 1 A 2 * 1 F)$ in the CYP1A2 gene. After this result, a mutation-specific test was developed, and a functional significance of this polymorphism was assessed in 185 healthy Caucasian non-smokers and in 51 smokers by genotyping and phenotyping using caffeine (100 mg/oral doses). The A variant (CYP1A2*1A) was more frequent $(46 \%, n=108)$ followed by the $\mathrm{A} / \mathrm{C}$ genotype $(44 \%, n=104)$, and almost $10 \%(n=24)$ corresponded to $\mathrm{C}$ variant (CYP1A2*1B). The authors observed a significant difference between the A/A and A/C genotypes in the $5 \mathrm{~h}$ plasma paraxanthine/caffeine ratios, but not between the $\mathrm{A} / \mathrm{C}$ and the $\mathrm{C} / \mathrm{C}$ genotypes and indicated that the A allele is a recessive factor for high inducibility. Differences among CYP1A2 fast and slow metabolizers still require further investigation. The importance given to the phenotype of individuals in relation to CYP1A2 activity using plasma, saliva or urine samples [177] is increasing, since it has been observed that this characteristic may influence the metabolism of individuals and may or not make them susceptible to developing certain diseases. For example, slow caffeine metabolization can enable the occurrence of side effects exposure [200] or make individuals more susceptible to hypertension development [201].

Few studies investigated whether genetic polymorphisms have an effect on coffee and caffeine consumption. Rodenburg et al. [202] studied the effect of CYP1A2*1F polymorphism and smoking on coffee intake in 6.689 subjects in the Netherlands. Smokers drank almost one cup of coffee $(0.90$ cup/day $\sim 110 \mathrm{~mL}$ ) per day, more than did non-smokers. A meta-analysis [203] of 47,341 individuals of European ancestry, including five studies within the United States, was performed using directly genotyped and 2.5 million single nucleotide polymorphisms (SNP). Two sequence variants were found to be significantly associated with increased coffee consumption: rs2472297-T, located between CYP1A1 and CYP1A2 at 15q24 $\left(P=5.2 \times 10^{-14}\right)$ and rs6968865-T, near AHR at 7p21 $\left(P=2.4 \times 10^{-19}\right)$. An effect of 0.2 cups a day per allele was observed for both SNP. According to the authors, possibly rs2472297-T and rs6968865-T allow people to consume more coffee because in these carriers clearance of caffeine is more effective as a result of higher CYP1A1 or CYP1A2 enzymatic activities. In agreement with this result, Tantcheva-Poór et al. [204] and Djordjevic et al. [169] observed that heavy coffee consumers have higher CYP1A2 activity than those drinking less coffee, whereas Carrillo and Benitez [205] observed that low CYP1A2 activity we more often found in subjects with toxic symptoms linked to caffeine consumption.

A more recent meta-analysis included 12 studies and looked at the association between habitual coffee intake and CYP1A2 rs762551 polymorphism that splits the population in AA (rapid caffeine metabolizers), AC and CC genotypes (slow caffeine metabolizers). The analysis showed an association between the AA genotype and coffee consumption [OR $=1.13,95 \%, C I=1.03-1.24, P=0.06]$. This association was found in men, individuals younger than 59 years, and Caucasians, but not in females, individuals older than 59 years, and Asians [206].

\subsection{Excretion}

Despite caffeine efficient penetration in tissues and fluids, there is no long-term accumulation of it or its metabolites in the body as seen by whole-animal autoradiography using radiolabeled caffeine [114,207] and in humans [114]. Various experimental and human studies have proved that caffeine is excreted mostly via kidneys. In humans, the total urinary excretion of monomethylxanthines (1-methylxanthine, 3-methylxanthine, and 7-methylxanthine), dimethylurate derivates (1,3-methyluric acid and 1,7-methyluric acid) and monomethylurates (1-methyluric acid), has been estimated to be equivalent to about $90-95 \%$ of the amount of caffeine orally administrated (5-7.5 mg of caffeine $/ \mathrm{kg}$ body weight-bw), and that less than $5 \%$ is recovered as caffeine itself $[114,208]$. After peaking, plasma concentrations of caffeine decrease more rapidly than those of its metabolite paraxanthine. Therefore, despite important interindividual differences, the concentration of paraxanthine becomes higher than that of caffeine within $8-10 \mathrm{~h}$ after administration [114,132]. Caffeine clearance is strongly dependent on renal blood flow and urine passage because this alkaloid and its primary metabolites are extensively reabsorbed (98\%) in renal tubule, but the final urine concentration significantly correlates with the 
plasma caffeine level, as well as fluid intake [114]. The fecal excretion is not so relevant because it covers only a small percentage (1-5\%) of the caffeine ingested [114]. The microbial products identified in human feces are: 1,7-dimethyluric acid (44\%), 1-methyluric acid (38\%), 1,3-dimethyluric acid (14\%) and 1,3,7-trimethyluric acid (6\%), and caffeine (2\%) [114,209].

\section{Health Benefits of Caffeine Consumption}

The most well-known acute effects of caffeine consumption are stimulation of brain function and improvement in mood, and physical performance [57]. However, along the past few years, several epidemiological studies have associated moderate coffee consumption with the reduction in the relative risk of development of chronic degenerative diseases and death [210-219], and caffeine is one of the compounds responsible for many of these benefits. They include reduction in the risk of Parkinson's and Alzheimer's diseases as well as hepatoprotective effects. The mechanisms involve antioxidant and anti-inflammatory activities, among others. The main caffeine benefits will be commented below.

\subsection{Caffeine, Mood, and Behavior}

Once caffeine is absorbed, it exerts a variety of pharmacological actions at diverse central and peripheral sites $[220,221]$. These effects are predominantly related to its antagonistic activity at adenosine receptors [222], which are widely distributed throughout the body, allowing the substance's wide range of effects. Of the four adenosine receptors $\left(\mathrm{A}_{1}, \mathrm{~A}_{2 \mathrm{~A}}, \mathrm{~A}_{2 \mathrm{~B}}\right.$, and $\left.\mathrm{A}_{3}\right)$, caffeine acts mainly as an antagonist to adenosine $A_{1}$ and $A_{2 A}$ receptors, that are expressed in the CNS [112,223]. In humans, $A_{1}$ and $A_{2 A}$ have been shown to be activated in normal plasma caffeine concentrations (10-50 $\left.\mu \mathrm{M}\right)$, while the other two receptors $\left(\mathrm{A}_{2 \mathrm{~B}}\right.$ and $\left.\mathrm{A}_{3}\right)$ are only stimulated at higher concentrations [223]. Thus, when caffeine intake is able to cause an extracellular concentration of 10-50 $\mu \mathrm{M}$, it selectively blocks adenosine receptors and competitively inhibits the action of adenosine [224]. Consequently, caffeine increases the responses from dopaminergic receptors [225] and the release of various neurotransmitters, such as norepinephrine, dopamine, and serotonin [226], stimulating psychomotor properties and improving behavioral functions, such as mood and wellbeing [227], sense of energy [228], and effects related to alertness, mental focus/attention [229,230], memory, speed at which information is processed [115,230], awareness, and reaction time $[227,229,231]$. According to EFSA [126], who reviewed all existing evidence of caffeine on mental performance, generally, a dose of $75 \mathrm{mg}$ is needed to obtain these effects, although very large differences in individual responses to caffeine are observed as stated above. There is a consensus that in most people, at low $(\sim 50-250 \mathrm{mg})$ to moderate doses $(\sim 250-400 \mathrm{mg})$ [123,231] or 1-5 mg caffeine/body weight/day for a 70-kg person [223] positive changes occur in mood and human behavior, such as enhanced energy, well-being, sociability, willingness and motivation to work, improved self-confidence and cognitive function, including enhanced alertness and mental focus, vigilance, learning and memory $[123,232]$. This is generally true for both caffeine-deprived and caffeine-tolerant individuals [223].

\subsection{Caffeine and Exercise Performance}

Caffeine exerts a positive effect on endurance and exercise capacity owing to the aforementioned neural mechanisms that trigger a chain of physiological reactions, which makes it an ergogenic resource [233]. Exercise performance is shown to be significantly improved by oral caffeine administration or by the consumption of dietary sources, either by avoiding fatigue, improving substrates supply or by enhancing oxygen uptake $[221,234]$. Ergogenic effects of caffeine are similar in both non-habitual and habitual caffeine consumers [235] and have been observed after administration of doses between 3 and $6 \mathrm{mg} / \mathrm{kg}$ of body weight $[233,236]$. Considering a $70 \mathrm{~kg}$ individual and a supplemented dose of $3 \mathrm{mg} / \mathrm{kg}$ of caffeine, the intake could be estimated in $210 \mathrm{mg}$ [237]. Caffeine also increases coordination [238] and reduces the perception of pain and fatigue [222]. Because caffeine increases metabolic rate, energy expenditure, lipid oxidation and presents lipolytic and 
thermogenic activities, all favorable components for weight management, coffee has been used for weight loss $[239,240]$.

Historically, in 1984 the International Olympic Committee had caffeine on the list of banned substances for urinary concentrations greater than $15 \mu \mathrm{g} / \mathrm{mL}$ (equivalent to 5-6 mg of caffeine/ $\mathrm{kg} \mathrm{bw}$ ), being considered a doping infraction [241]. In 2003, the World Anti-Doping Agency (WADA) included caffeine in the list of stimulants banned from sports competitions, with a maximum allowed urinary concentration of $12 \mu \mathrm{g} / \mathrm{mL}$ [242]. However, it was observed that both the commonly consumed doses and the supplementation doses indicated to promote ergogenic effect ( 3 to $6 \mathrm{mg} / \mathrm{kg} \mathrm{bw}$ ) resulted in urinary concentrations far below the limit proposed by WADA. Because of the difficulty to differentiate the low levels of habitual caffeine ingestion from the intentional use of caffeine to improve athletic performance, WADA removed caffeine from the list of prohibited substances in 2004 and added it to its monitoring program [243], which includes substances that are not prohibited in sport, but which WADA examines in order to detect patterns of misuse [237].

\subsection{Caffeine and Antioxidant and Antiinflammatory Activities}

Some of the beneficial health effects reported for caffeine have been associated with antioxidant properties [244-250] although not all studies have found such activity at physiological micromolar concentrations [251]. Caffeine has been reported to be an efficient scavenger of hydroxyl radicals generated by the Fenton reaction [239], evaluated by electron spin resonance spin trapping, and it has also been reported to inhibit lipid peroxidation of rat liver microsomes at millimolar concentration by reducing the production of TBARS (thiobarbituric acid reactive substances) and lipid hydroperoxides [252]. Caffeine metabolites, especially 1-methylxanthine,1-methyluric acid [251], and 1-methylurate [253] have also exhibited effective in vitro antioxidant activity, in the case of 1-methylxanthine, equivalent to ascorbic acid activity. Caffeine intake has also been responsible for an increase in glutathione levels in rats [250]. Corroborating in vitro results, the average plasma iron-reducing capacity of human subjects was higher after regular coffee consumption than after decaffeinated coffee consumption [254], suggesting that whole coffee is more efficient than decaffeinated coffee in respect to its antioxidant capacity. This was later confirmed by other studies $[255,256]$.

Since inflammation is correlated with and influenced by various cytokines and chemokines, reduction of these markers should decrease the degree of overall inflammation [257]. The anti-inflammatory action of caffeine is thought to be related to phosphodiesterase inhibition and/or with adenosine receptor antagonism mechanisms [244,258]. Caffeine anti-inflammatory potential has also been linked to modifications in cell signaling molecules production [259]. In many studies, caffeine potentiated the release of anti-inflammatory cytokines, including interleukin 10 (IL-10) [260,261]. Additionally, caffeine mediates immune-suppression of pro-inflammatory cytokines release, including tumor necrosis factor alpha (TNF- $\alpha$ ), interleukin 2 (IL-2) and interferon-gamma (IFN- $\gamma$ ), which have a central role in autoimmune disease initiation and propagation [262,263].

\subsection{Caffeine and Antimicrobial Activity}

Regarding caffeine's antimicrobial activity, there are a few in vitro studies showing that caffeine contributes to the antibacterial effect of coffee against Streptococcus mutans, the main cariogenic bacteria [264], as well as intestinal pathogenic bacteria's [265,266]. Additionally, a study showed the effectiveness of caffeine in inactivating and inhibiting significantly the growth of Escherichia coli O157:H7 in brain heart infusion broth, indicating that caffeine has potential as an antimicrobial agent for the treatment of E. coli O157:H7 infection and could be investigated further as an eventual food additive to increase bio-safety of consumable food products [267].

\subsection{Caffeine and Neurodegenerative Diseases}

The effect of caffeine on neurodegenerative diseases has gathered considerable attention in the last years [244]. Several studies have reported that regular coffee/caffeine intake is related to lower risk 
of neurodegenerative diseases development, especially Parkinson's and Alzheimer's [245,268-272], and prevention of memory decline during aging [273,274]. A few findings from selected studies and meta-analyses are presented here.

Parkinson's disease is characterized by selective degeneration of dopaminergic neurons in the midbrain with a clinical presentation of motor and non-motor symptoms and by the prominent alpha-synuclein-containing proteinaceous inclusions, called Lewy bodies $[275,276]$. Coffee consumption appears to reduce the risk of Parkinson's disease or to delay its onset [238], by attenuating dopaminergic neurodegeneration [277]. In a meta-analysis of 26 studies from the USA, Europe, and Asia, a 25\% lower risk of Parkinson's disease was found in coffee drinkers as compared to non-coffee drinkers $[237,271]$. The overall risk has been reported to fall at least by $24-32 \%$ per $300 \mathrm{mg}$ (three cups of $100 \mathrm{mg}$ ) increase in caffeine intake [271]. Higher risk reduction (up to $80 \%$ ) have been suggested for the intake of more than four cups of caffeinated coffee daily [231]. This inverse relationship was confirmed by similar findings in two larger ethnically diverse cohorts involving 47,351 men and 88,565 women. In both studies, the consumption of caffeinated (but not decaffeinated) coffee was associated with reduced risk of developing Parkinson's disease $[277,278]$.

Differences between genders [278] regarding the association of caffeine intake and the risk of Parkinson's disease have been reported: while for men a strong inverse association was found, for women, this association was non-linear ("U-shaped"), with the lowest risk occurring at moderate intake (one to three cups/day). The authors further investigated this difference in two large cohorts in the USA $[279,280]$ and found an interaction among the use of postmenopausal hormones, caffeine intake, and risk of Parkinson's disease. In one of the cohorts, the risk was increased among women who were in hormonal replacement therapy [279]. In the second cohort, the risk was increased among hormone users who were heavy coffee drinkers (more than six cups/day) [280]. The reason for the interference of estrogens on the protective effect of coffee was not clear $[279,280]$. Additional studies involving caffeine protection against Parkinson's disease development are presented in Table 3.

Alzheimer's disease is the most frequent cause of dementia, leading to a progressive cognitive decline [237]. Definitive diagnosis of Alzheimer's disease is based on the presence of senile plaques and neurofibrillary tangles that are identified in post-mortem brain specimens [281]. The formation of Alzheimers' disease-specific lesions is attributed to the pathological accumulation of either toxic extracellular amyloid beta peptide in the brain [282], or intraneuronal hyperphosphorylated Tau protein [283]. Constituents of the lesions are prone to promote synaptic deficits leading to memory impairments [284]. Currently, there is no medication against Alzheimer's disease once it is installed [285], but there are a few ways of preventing it, among them the consumption of foods rich in polyphenols and caffeine [281]. A meta-analysis has reported an inverse association between regular coffee consumption and the development of Alzheimer's disease, with a $27 \%$ risk reduction observed in the highest category of coffee consumption compared with the lowest [286]. The mechanism for caffeine protection is believed to be related to an anti-inflammatory effect on the A1 and A2 receptors as well as to the reduction in the deposits of toxic beta-amyloid peptide in the brain [287]. Alzheimer's disease mouse model study confirmed these findings, reporting that heavy coffee intake (the human equivalent of $500 \mathrm{mg}$ caffeine or five coffee cups/day) was able to protect against and could treat Alzheimer's disease [287].

Exceptionally, in a study evaluating Japanese-American men, the authors did not find a significant association between caffeine intake and the risk of dementia [288]. However, they interestingly reported that, at autopsy, patients in the highest quartile of caffeine intake ( $>277.5 \mathrm{mg} /$ day-all caffeine sources) were less likely to have any of the neuropathological lesions, such as Alzheimer's disease-related lesions, ischemic microvascular lesions, cortical Lewy bodies, hippocampal sclerosis or generalized atrophy [288]. Additional studies on the protective effect of caffeine against Alzheimer's disease are presented in Table 3. 


\subsection{Caffeine and Liver Diseases}

In the past three decades, caffeine has been related to a lower incidence of chronic liver diseases, such as cirrhosis and hepatocellular carcinoma [289-291]. Additionally, in several studies, regular coffee consumption has been significantly associated with reduced hepatic fibrosis related or not with non-alcoholic fatty liver disease [292] and with chronic hepatitis C [293]. In 2016, The International Agency on Research on Cancer (IARC) evaluated several studies [294] and concluded that higher coffee consumption was associated with lower blood concentrations of biomarkers of liver damage, including alanine aminotransferase and $\gamma$-glutamyl transferase [295]. Moreover, in prospective studies, coffee consumption was associated with a lower risk of liver cirrhosis [296]. Two important meta-analyses that combined data from cohort and case-control studies, adjusting the results for potential confounders (age, sex, alcohol intake, smoking, and history of liver diseases), confirmed the inverse association between coffee consumption and liver cancer [297,298].

Caffeine, together with other bioactive compounds, such as chlorogenic acids and trigonelline, has been reported to be responsible for coffees' hepatoprotective effect. The mechanisms underlying the potential benefits of caffeine have not yet been fully determined. However, some plausible explanations have been suggested [291]. In patients with chronic hepatitis C, a suggested possible mechanism would be the alteration in liver signaling and inflammatory pathways [291]. In a rat model, caffeine suppressed connective tissue growth factor expression by interfering with a profibrogenic cytokine, transforming growth factor beta (TGF- $\beta$ ) signaling through the Smad pathway [299]. Smad comprises a family of structurally similar proteins that are the main signal transducers for receptors of TGF- $\beta$, which are critically important for regulating cell development and growth. Caffeine also has a direct inhibitory effect on hepatic stellate cells by downregulating focal adhesion kinase and actin synthesis and also induces hepatic stellate cells apoptosis [300]. Additional studies on the protective effect of caffeine on the liver are presented in Table 3.

Table 3. Complementary studies on the protective effect of caffeine against neurodegenerative and hepatic diseases.

\begin{tabular}{|c|c|c|c|c|}
\hline $\begin{array}{l}\text { Subjects' } \\
\text { Origin }\end{array}$ & Sample & Study Type & Conclusions & Reference \\
\hline \multicolumn{5}{|c|}{ Neurodegenerative diseases } \\
\hline Finland & $n=6.710$ & $\begin{array}{l}\text { Large prospective study } \\
\text { (follow-up for } 22 \text { years) }\end{array}$ & $\begin{array}{l}\text { Results support the hypothesis that coffee } \\
\text { consumption reduces the risk of } \\
\text { Parkinson's disease. }\end{array}$ & [301] \\
\hline Greece & $n=26.173$ & $\begin{array}{l}\text { Population-based } \\
\text { prospective cohort } \\
\text { (follow-up for } \\
3-5 \text { years) }\end{array}$ & $\begin{array}{l}\text { Results support the hypothesis that coffee } \\
\text { consumption reduces the risk of } \\
\text { Parkinson's disease. }\end{array}$ & [302] \\
\hline Denmark & $n=1.876$ & $\begin{array}{l}\text { Large case-control } \\
\text { study }\end{array}$ & $\begin{array}{c}\text { Moderate coffee intake ( } 3.1-5 \text { cups/day) } \\
\text { was associated with a lower odds ratio for } \\
\text { Parkinson's disease. }\end{array}$ & [303] \\
\hline $\begin{array}{l}\text { Mostly from } \\
\text { USA, Europe, } \\
\text { and Asia }\end{array}$ & - & $\begin{array}{l}\text { Dose-response } \\
\text { meta-analysis }\end{array}$ & $\begin{array}{l}\text { Non-linear relationship between coffee } \\
\text { intake and the risk of Parkinson's disease } \\
\text { was found, with maximum protection effect } \\
\text { at approximately } 3 \text { cups/day and no } \\
\text { improvement after that. }\end{array}$ & [304] \\
\hline Canada & $n=6.434$ & $\begin{array}{l}\text { Prospective analysis of } \\
\text { risk factors (follow-up } \\
\text { for } 5 \text { years) }\end{array}$ & $\begin{array}{l}\text { Daily coffee consumption decreased the } \\
\text { risk of Alzheimer's disease by } 31 \% \text { during } \\
\text { the follow-up. }\end{array}$ & [305] \\
\hline Finland & $n=1.409$ & $\begin{array}{l}\text { Population-based } \\
\text { cohort study (follow-up } \\
\text { for } 21 \text { years) }\end{array}$ & $\begin{array}{l}\text { Coffee drinkers at midlife had a lower risk } \\
\text { of dementia and Alzheimer's disease later } \\
\text { in life compared to those who drank no or } \\
\text { little coffee, with lower risk ( } 65 \% \text { decreased) } \\
\text { in those who drank } 3-5 \text { cups per day. }\end{array}$ & [269] \\
\hline $\begin{array}{l}\text { Mostly from } \\
\text { USA, Europe, } \\
\text { and Asia }\end{array}$ & - & Systematic review & $\begin{array}{l}\text { Findings indicate that moderate } \\
\text { coffee/caffeine intake decreases the risk of } \\
\text { cognitive impairment/decline and } \\
\text { dementia/Alzheimer's disease later in life. }\end{array}$ & [306] \\
\hline
\end{tabular}


Table 3. Cont.

\begin{tabular}{|c|c|c|c|c|}
\hline $\begin{array}{l}\text { Subjects' } \\
\text { Origin }\end{array}$ & Sample & Study Type & Conclusions & Reference \\
\hline \multicolumn{5}{|c|}{ Liver diseases } \\
\hline $\begin{array}{l}\text { Mostly from } \\
\text { USA, Europe, } \\
\text { and Asia }\end{array}$ & - & $\begin{array}{l}\text { Systematic review and } \\
\text { dose-response } \\
\text { meta-analysis }\end{array}$ & $\begin{array}{l}\text { Regular intake of three cups of caffeinated } \\
\text { and decaffeinated coffees was associated } \\
\text { with reductions of } 27 \% \text { and } 14 \% \text { in the risk } \\
\text { of hepatocellular carcinoma, respectively. }\end{array}$ & [307] \\
\hline $\begin{array}{l}\text { USA, France } \\
\text { and Brazil }\end{array}$ & - & $\begin{array}{l}\text { Systematic review and } \\
\text { meta-analysis }\end{array}$ & $\begin{array}{l}\text { Decreased risk of advanced liver fibrosis } \\
\text { and liver inflammation among hepatitis C } \\
\text { virus-infected patients who consumed } \\
\text { caffeine on a regular basis. }\end{array}$ & [308] \\
\hline USA & $n=5.944$ & $\begin{array}{l}\text { Population-based } \\
\text { cohort study }\end{array}$ & $\begin{array}{l}\text { Dose-effect relationship between coffee and } \\
\text { caffeine consumption and decrease in } \\
\text { aminotransferase (ALT) levels, reducing the } \\
\text { prevalence of above-normal ALT value by } \\
50 \% \text { for two cups/day, and by } 66 \% \text { for three } \\
\text { cups/day. }\end{array}$ & [309] \\
\hline Italy & $n=732$ & Population-based study & $\begin{array}{l}\text { Coffee caffeine may inhibit the onset of } \\
\text { alcoholic and nonalcoholic liver cirrhosis. }\end{array}$ & [310] \\
\hline
\end{tabular}

\section{Potential Adverse Effects of Caffeine Consumption}

\subsection{Caffeine Acute and Chronic Toxicity}

Based on scientific evidence, moderate caffeine consumption is currently considered by EFSA [126], Food and Drug Administration (FDA) [311] and the Scientific Committee on Food within the European Commission (SCF) [312], among other health authorities, to be a safe habit. However, caffeine acute toxicity effects related to excessive intake may occur and are well characterized. The first studies on the toxicity of caffeine were performed in the 19th century, initially with animals [313], and soon after, with humans [314]. In 1850, Lehmann [314] reported several adverse symptoms after acute oral administration of 2 to $10 \mathrm{~g}$ of caffeine. Such intoxication results in 'caffeinism', which refers to a syndrome characterized by a range of adverse reactions, for instance, restlessness, nervousness, anxiety, irritability, agitation, muscle tremor, insomnia, headache, diuresis, tachycardia, arrhythmia, pulse irregularity and increased frequency, elevated respiration and gastrointestinal disturbances (e.g., nausea, vomiting, diarrhea) [315]. Besides tachycardia and diuresis, caffeine toxicity in children has also been implicated in severe emesis, photophobia, palpitations, muscle twitching, convulsions, and unconsciousness, especially at doses around $80 \mathrm{mg} / \mathrm{kg}$ of body weight [14].

Regarding lethality, caffeine death-related reports in humans are unusual, implying rather significant concentrations which are not provided by regular coffee drinking. Only a few cases have been reported in the literature [316]. Concerning the exact dose, as previously mentioned, the metabolism and physiological effects of caffeine vary greatly, depending on several factors. For slow metabolizers, the lethal dose will be lower than for fast metabolizers. Foods or medications taken simultaneously will affect caffeine metabolism and, therefore, also the lethal acute dose [316]. Other complications would be age and previously existing cardiovascular diseases or other types of diseases. According to Frerichs [317], severe symptoms might be induced in humans about 15 min after oral administration of $25 \mathrm{~g}$ of the drug, which is an extremely high amount. Currently, studies using potentially lethal doses (LD) are not performed in humans, and the perception of LD is only based on extrapolation of animal studies or case reports. Tarka and Cornish [318] determined the LD50 (the amount given acutely which causes death of $50 \%$ of the animals) for caffeine in rats and extrapolated the results to humans. According to them, the LD 50 for caffeine in humans would be about 192 $\mathrm{mg} / \mathrm{kg}$ of body weight. For Cappelletti et al. [245] the LD of caffeine should be about $10 \mathrm{~g} /$ day, which according to the authors could be comparable to drinking 100 cups of instant coffee. Arnaud [14] also estimated in $10 \mathrm{~g}$ the acute LD of caffeine which they extrapolated to $150-200 \mathrm{mg} / \mathrm{kg}$ bw in agreement with Tarka and Cornish [318], but death has been reported after ingestion of $6.5 \mathrm{~g}$ of caffeine [14], which 
is in agreement with a report from Kerrigan and Lindsey [319] suggesting lethal doses to be typically in excess of $5 \mathrm{~g}$, although according to the authors, there has been several cases in which adults and teenagers consumed between $5-10 \mathrm{~g}$ and survived. The survival of a patient who supposedly ingested $24 \mathrm{~g}$ of caffeine has also been reported [315,320].

In general, high chronic exposure to caffeine (more than 400-600 mg/day) has also been associated with a range of dysfunctions involving the gastrointestinal, liver and renal systems, besides musculature [315,320], unstable bladder, mainly developed in women [321]. In more extreme cases, symptoms may include myopathy, hypokalemia, muscular weakness, nausea, vomit, diarrhea, and weight loss [322].

Following, the most commonly reported potential negative effects of acute and chronic caffeine consumption on the human body are discussed, especially the effects on CNS and behavior, cardiovascular system, glucose metabolism, bone and calcium balance, reproductive and development effects and carcinogenesis. Caffeine withdrawal syndrome will also be approached.

\subsection{Potential Adverse Effects of Caffeine on Mood, Behavior, and Sleep}

The effects of caffeine on mood in adults have been extensively studied and the most common negative effects reported after caffeine intake are related to its stimulating effects due to the aforementioned responses in dopaminergic $D_{1}$ and $D_{2}$ receptors [225] and release of neurotransmitters, such as norepinephrine, dopamine, and serotonin [112]. Although ingestion at low to moderate doses tends to licit the pleasant sensations previously described in this review, higher doses consumed either on a single occasion or within short periods of time can produce or exacerbate jitteriness, insomnia (especially in those who are caffeine-abstinent) [112], nervousness and anxiety, especially in those with preexisting psychiatric anxiety disorders, but also in healthy adults, particularly when they are non-habitual caffeine consumers [232]. The dose range considered to cause anxiety and mood change varies considerably among authors and official guidelines, from 400 to $2000 \mathrm{mg}$ caffeine/day [14,232,323-325]. In slow metabolizers, such negative effects can be felt at much lower doses compared to fast metabolizers, as low as $50 \mathrm{mg}$ or less. After repeated intake, however, tolerance to general effects of caffeine is usually observed. The mechanism to increase tolerance is not well understood and is highly variable among the population, but it has been attributed to upregulation of adenosine receptors [112]. However, in adults, tolerance to such anxiogenic effect develops with frequent caffeine consumption, even in genetically susceptible individuals [326]. The inter-individual variability in the anxiogenic response to caffeine intake has been suggested to be caused by a single nucleotide polymorphism in the gene coding for the adenosine $A_{2 A}$ receptor $\left(A_{D O R A} A\right)[326,327]$. In any case, such high doses are consumed only by a small segment of caffeine consumers, and individuals experiencing the anxiogenic effects of caffeine as well as slow metabolizers who are sensitive to its effects in general are likely to avoid the use of the substance [315]. Thus, the self-limiting nature of caffeine intake reduces caffeine potential to produce anxiety in adults [326,327].

Regarding sleep, in adults, single doses equivalent to about $100 \mathrm{mg}$ of caffeine or more $(1.5 \mathrm{mg} / \mathrm{kg}$ bw/day in a $70 \mathrm{~kg}$ adult) have increased sleep latency, in a dose-dependent manner and reduced sleep duration when consumed close to bedtime [328]. This may be accompanied by impairment of sleep quality, characterized by an increased number of spontaneous awakenings and body movements. Doses lower than $100 \mathrm{mg}$ do not appear to have such an effect on sleep in most people [14,329]. Chronic high consumers of caffeine, however, are less likely to report sleep disturbances than individuals consuming caffeine more occasionally, also suggesting the development of tolerance to the effects of caffeine on this parameter [330].

There seem to be only a few human intervention studies, meta-analysis and controlled trials investigating the effects of caffeine on psychological, behavioral, cognitive functions and sleep of children and adolescents [331-342]. In an earlier study by Rapoport et al. [333], daily caffeine consumption was investigated for two weeks in relation to self-reported anxiety, parents/teachers' ratings of children's behavior and side effects in pre-pubertal children. Data from 19 children were 
analyzed depending on whether they were "low" (up to $50 \mathrm{mg} /$ day) or "high" (more than $300 \mathrm{mg} / \mathrm{day}$ ) caffeine consumers. The results provided evidence that "high" habitual caffeine consumers (and their parents) tended to report more side effects during the caffeine withdrawal period, compared to "low" caffeine consumers, suggesting the development of tolerance and withdrawal symptoms in "high" habitual consumers. Moreover, in "high" habitual caffeine consumers, despite the significant improvements in tasks related to vigilance and significant increases in locomotor activity, symptoms as "nervous/jittery" were also reported, although not classified as anxiety $[126,333]$. Considering the existing literature data on the subject up to 2015, according to EFSA [126], regular consumption of caffeine (up to about $3 \mathrm{mg} / \mathrm{kg}$ bw/day, approximately 60-120 $\mathrm{mg}$ of caffeine/day) does not appear to induce behavioral changes in children and adolescents.

\subsection{Potential Adverse Effects of Caffeine on Cardiovascular System}

Investigations regarding the effects of caffeine consumption on the cardiovascular system generally focus on evaluating the heart functioning as the onset of morbi-mortality covering the main risk factors. For this, it is especially important to distinguish acute from long-term cardiovascular effects of caffeine [126,172]. Single 200-250 mg doses of pure caffeine acutely increased plasma renin activity, catecholamine concentrations, and blood pressure, and were able to induce cardiac arrhythmias (mostly atrial) in healthy subjects $[343,344]$.

Possible mechanisms for the acute cardiovascular effects of caffeine include antagonistic action on adenosine receptors, activation of the sympathetic nervous system (release of catecholamines from adrenal medulla), stimulation of adrenal cortex (release of corticosteroids), renal effects (diuresis, natriuresis, activation of the renin-angiotensin-aldosterone system), and inhibition of phosphodiesterase's (increase in cyclic nucleotides), although the contribution of each of these mechanisms to the acute cardiovascular effects of caffeine is unclear [126,201], and may depend on the source of caffeine, the dose administered, and on plasma concentrations prior to caffeine administration [126].

According to epidemiological data, the coffee effect on blood pressure differs with CYP1A2 genotype [345]. While in fast caffeine metabolizers (CYP1A2*1A) the effect of caffeine on blood pressure seems to be insignificant, in slow metabolizers (CYP1A2*1F) the hypertensive effect seems to prevail [345]. However, it has been observed that in fast metabolizers, caffeinated cola consumption, but not coffee, has been associated with hypertension, which may be due to the lack of polyphenols in the cola beverages [345]. Watanabe et al. [346] examined the blood pressure-lowering effect of chlorogenic acids (the main polyphenols in coffee) in patients with mild hypertension through a placebo-controlled, randomized clinical trial. Subjects $(n=28)$ were randomized to receive treatment with chlorogenic acids (140 mg/day) from green coffee extract or placebo daily for 12 weeks. In the chlorogenic acids group, but not in the placebo group, blood pressure (systolic and diastolic) decreased significantly during the ingestion period, demonstrating the hypotensive action of coffee phenolic compounds, a mechanism that seems to involve nitric oxide-mediated vasodilation [347].

Comparing the hypertensive effect with frequency of caffeine consumption, acute increases in systolic and diastolic blood pressures, as well as in pulse pressure have been reported after single doses of caffeine ranging from 80 to $250 \mathrm{mg}$, in coffee abstainers and in habitual caffeine consumers, after 12 to $48 \mathrm{~h}$ withdrawal [126,348-350]. Although the hypertensive effect of caffeine was observed in many repeated-dose studies, it was not as consistent as in the acute-dose studies [344]. Tolerance usually develops within a couple of days, and it is accompanied by a reduced release of adrenaline, noradrenaline, and rennin, compared with the non-tolerant state. Although fast tolerance development has been observed in habitual coffee drinkers (within one to three days), the hypertensive response is regained after relatively brief periods of abstinence $(12 \mathrm{~h})$ and depends on how much caffeine is consumed, the schedule of consumption, and on the half-life and elimination of caffeine from the body [351,352]. 
Caffeine intake has also been associated with the occurrence of arrhythmias in humans. It produces a direct stimulation of myocardial tissue, leading to increased heart rate and force of contraction [14]. Cardiovascular disease has been assessed by a range of outcome variables, including death from myocardial infarction or Coronary Heart Disease (CHD), non-fatal myocardial infarction or coronary event, angina pectoris and/or hospitalization for CHD. Prospective epidemiological studies and case-control studies were more likely to show an increased risk in cardiovascular disease onset only when five or more cups of coffee were consumed per day ( $\geq 500 \mathrm{mg}$ caffeine/day) [353-357]. However, as with blood pressure, in patients with a history of cardiovascular disease, slow caffeine metabolizers (CYP1A2*1F), were associated with increased risk of myocardial infarction when coffee consumption was increased [199]. Additional studies on the effect of caffeine on blood pressure and cardiovascular diseases are presented in Table 4.

\subsection{Potential Adverse Effects of Caffeine on Glucose Metabolism and Insulin Resistance}

Coffee consumption has been associated with reduced risk of type 2 diabetes [358-364]. However, a key issue that remains to be resolved is whether the consumption of caffeinated and decaffeinated coffees is similarly associated with the reduced risk of type 2 diabetes $[365,366]$. Shearer et al. [365] observed that glucose infusion rates and measures of whole-body metabolic clearance were greater in rats that received decaffeinated coffee $(2 \mathrm{~g} / 100 \mathrm{~mL})$ than in placebo or caffeine $(20 \mathrm{mg} / 100 \mathrm{~mL})$ added to decaffeinated coffee $(2 \mathrm{~g} / 100 \mathrm{~mL})$, indicating increased whole-body insulin sensitivity in decaffeinated coffee. It was concluded that caffeine can antagonize the beneficial effects of decaffeinated coffee. Most evidence, in fact, indicates that caffeine alone promotes adverse effects on glucose metabolism [366-368] and reduces insulin sensitivity $[364,369]$. The intake of about $500 \mathrm{mg} /$ day by usual coffee drinkers was associated with higher average daytime glucose concentrations and exaggerated post-prandial glucose responses in diabetic patients [366]. In healthy individuals, the ingestion of caffeinated coffee with either a high or a low glycemic index meal significantly impaired acute blood glucose management and insulin sensitivity compared with decaffeinated coffee [367]. These effects could be partially explained by the direct inhibition of glucose uptake in adipocytes and skeletal muscle through antagonism of adenosine receptors [370] or possibly as a result of elevated plasma epinephrine [371].

On the other hand, both caffeinated and decaffeinated coffee consumption enhanced insulin sensitivity in a cross-sectional study [372] and in epidemiological studies [373-376], suggesting beneficial effects of both drinks on glucose homeostasis. Other studies have found that when controlling for total coffee intake, caffeine intake was not associated with diabetes risk [363,364], showing that the consumption of both decaffeinated e and caffeinated coffees is significantly associated with a lower risk of developing type 2 diabetes [358,359,366,373,374]. As with blood pressure, although most data from short- and long-term studies indicate that caffeine intake promotes adverse effects on glucose metabolism [377-379], evidence points out that coffee components other than caffeine, especially chlorogenic acids and trigonelline [102,365,380], exert several positive effects on glucose homeostasis, balancing caffeine effects [364,378-382].

In conclusion, although regular consumption of both decaffeinated and regular coffees is proved to reduce the risk of diabetes, decaffeinated beverages seem to be more beneficial for glycemic control than caffeinated ones, although most epidemiological studies have failed to discriminate the effects of these two types of coffee on the protective effect of coffee against type 2 diabetes. Additional studies on this topic are presented in Table 4.

\subsection{Potential Adverse Effects of Caffeine on Calcium Balance}

This is one of the most discussed potential adverse effects of caffeine intake. Caffeine potential to adversely influence calcium excretion and bone metabolism was investigated by epidemiological studies which evaluated the relationship between caffeine intake and the risk of fracture and fall [383-387], bone mineral density (BMD) and osteoporosis [388-393], and the effect on calcium homeostasis [394,395]. On the potential risk factor for bone fracture and fall, most studies reported a lack of association between 
caffeine intake and increased risk of fracture considering consumption below $400 \mathrm{mg} / \mathrm{day}$ [383-387]. However, in a cross-sectional study, caffeine intake was associated with an increased incidence of low trauma fractures [396]. When the consumption was estimated in more than $544 \mathrm{mg}$ caffeine/day, consumers had a higher risk of hip fracture than those who 'almost never' consumed coffee. Hallström et al. [397] also reported that a daily intake of $\geq 330 \mathrm{mg}$ caffeine might be associated with a modestly increased risk of osteoporotic fractures (relative risk (RR): 1.20, CI: 1.07-1.35), especially in women with low calcium intake. However, when stratified by calcium intake, the increased risk was only significant when calcium intake was low (less than $700 \mathrm{mg} /$ day). No trend in increased risk of osteoporotic fractures was observed with higher caffeine intake in participants with high calcium intake.

Caffeine consumption of $175 \mathrm{mg} /$ day has been positively associated with increased 24-h urinary calcium excretion [398]. Heaney and Rafferty [394] also reported that acute consumption of caffeinated beverages (60-92 mg caffeine) produced small increases in calcium excretion, which, according to the authors, could be offset by small increases in calcium intake $(15-30 \mathrm{~mL}$ of milk). Based on a study group of women who habitually consumed low-calcium, Ribeiro-Alves et al. [395] reported that exposure to $285 \mathrm{mg}$ caffeine resulted in increased calcium excretion. However, in another study by Barger-Lux et al. [399], when a greater amount of caffeine was ingested by healthy premenopausal women for a prolonged time ( $400 \mathrm{mg} /$ person/day for 19 days), no effect on calcium absorption, endogenous fecal calcium or urinary calcium excretion was found, despite the observation of bone remodeling. Interpretation of caffeine's effects on bone metabolism is complex since caffeine intake is usually associated with other risk factors for osteoporosis, such as lower calcium intake [393,400] and advanced ages [401,402]. Considering all available data, and evaluating the same population of postmenopausal women studied by Barger-Lux et al. [399], a model was elaborated: coffee intake higher than $1000 \mathrm{~mL} /$ day (760 mg caffeine/day) could induce excess calcium loss, while intakes of 150-300 mL coffee/day (112-224 mg caffeine/day) would have little impact on calcium balance [403].

The effect of coffee consumption on BMD in elderly men and women, with regards to the CYP1A2 genotype, was recently evaluated by Hallström et al. [397]. A decrease in BMD of the proximal femur was observed in men consuming four or more cups of coffee daily. It was also found that, in high coffee consumers, fast caffeine metabolizers had lower BMD values than slow metabolizers. Considering that in a higher CYP1A2 activity condition caffeine is more rapidly metabolized and the concentrations of its metabolites in plasma increase in relation to the parent compound, it was suggested that the deleterious effects of coffee consumption on bone might be due to caffeine metabolites, especially paraxanthine [391]. This metabolite has been found to be a potent suppressor of transforming growth factor beta (TGF- $\beta$ ) in vitro [404], which stimulates bone formation [405]. Moreover, deactivation of the adenosine receptors, which are expressed in bone cells, can result in reduced bone formation [406]. Since paraxanthine acts through the same mechanism as caffeine, that is the competitive antagonism interaction with $\mathrm{A}_{1}$ and $\mathrm{A}_{2}$ adenosine receptors [405], it could also act on such signaling pathway to reduce bone formation. Therefore, paraxanthine seems to be the main contributor to the coffee effect on BMD reduction, being the rapid metabolizers of caffeine at higher risk for bone loss induced by coffee than slow metabolizers [391].

Considering all previously published data, Nawrot et al. [232] concluded in a review published in 2003 that caffeine intake lower than $400 \mathrm{mg} /$ day does not have significant effects on bone status or calcium balance in individuals ingesting at least $800 \mathrm{mg}$ calcium/day. No other recommendations were made thereafter. Additional studies on this topic are presented in Table 4.

\subsection{Potential Adverse Effects of Caffeine on Fertility and Reproductive and Developmental Effects}

The effects of caffeine consumption have been reviewed in terms of reproduction or fertility [407-410] and in terms of pregnancy outcomes, including spontaneous abortion, birth weight, gestational length, and congenital malformations [410]. Consistent relationships between caffeine intake and subfecundity have not been observed to date. However, bringing together existing data available up to 2003, Nawrot et al. [232] suggested that the consumption of caffeine at doses greater 
than $300 \mathrm{mg} /$ day might reduce fecundability in fertile women. In respect to male fertility, Dlugosz and Bracken [407] suggested that doses higher than $400 \mathrm{mg} /$ day might decrease sperm motility and/or increase the percentage of dead spermatozoa, but not sufficiently to affect the male fertility in an adverse manner.

Once pregnant, women who regularly consume caffeine may be at risk of miscarriage, but current evidence of spontaneous abortion remains insufficient to allow conclusions regarding the potential role of caffeine [411]. The existing data do not support convincing results that caffeine consumption increases the risk of any perinatal adversity [412]. Nevertheless, based on several studies evaluating the association of caffeine intake and risk of perinatal adversities, Nawrot et al. [232] advised that women who are pregnant or are planning to become pregnant should limit the consumption of caffeine to less than $300 \mathrm{mg} /$ day, which is historically a common amount consumed by this group with no adversities [413].

The potential adverse impact of caffeine consumption during pregnancy on fetal growth has also been a concern for many years. Caffeine increases the levels of cyclic adenosine monophosphate through inhibition of phosphodiesterase's, which might interfere with fetal cell growth and development [414]. It is known that caffeine ingested by the mother is rapidly absorbed from the gastrointestinal tract and readily crosses the placenta, being distributed to all fetal tissues, including the CNS. Once present in the fetus organism, caffeine has increased half-life due to the immaturity of the enzyme complex involved in its metabolism. Therefore, if a pregnant woman does not limit her caffeine intake, the fetus and neonate may be exposed to substantial amounts of caffeine and metabolites and may suffer the consequences of potentiated adverse effects [14]. According to Rosenberg et al. [415], no association was found between drinking caffeine-containing beverages at levels up to $400 \mathrm{mg}$ caffeine/day and five types of malformation (inguinal hernia, oral clefts, cardiac defects, pyloric stenosis, neural tube defects) in a case-control study. These results were ratified by Olsen et al. [416]. Although published results are not yet entirely consistent, evidence suggests that caffeine intake at doses higher than $300 \mathrm{mg} / \mathrm{day}$ may cause adverse effects on some fetus developmental parameters, such as fetal intrauterine growth retardation or decrease in birth weight $[407,417]$. Being cautious, based on two prospective cohort studies that investigated positive association between caffeine intake during pregnancy and risk of adverse birth weight-related outcomes [418,419], EFSA [126] concluded that caffeine intake from all sources up to $200 \mathrm{mg} /$ day by pregnant women in the general population does not raise safety concerns for the fetus. The association between caffeine intake and other adverse pregnancy-related outcomes was less consistent [419]. Additional studies on this subject are presented in Table 4.

\subsection{Potential Carcinogenicity of Caffeine}

In 1983, a safety assessment on caffeine consumption was performed by the SCF within the European Commission [312]. Comparatively high doses of caffeine had shown weak teratogenic effects in experimental animals and mutagenic effects in vitro, but not in vivo, and it was concluded that there was no evidence for concern over carcinogenic, teratogenic, or mutagenic effects of caffeine in man at the actual levels of intake (between 2.0 and $4.5 \mathrm{mg} / \mathrm{kg}$ of body weight/day) and that human epidemiological studies provided no evidence for any association between coffee consumption and congenital defects [312]. In 1987, caffeine underwent another extensive review in which the FDA declared its safety for all consumers, including children. In 1991, several studies suggesting the potential carcinogenic effects of coffee, specifically regarding bladder [420-422] have led IARC [423] to classify coffee as possibly carcinogenic to humans, based on limited evidence of association with cancer of the urinary bladder from case-control studies, and inadequate evidence of carcinogenicity in experimental animals. However, IARC [423] concluded that there was no evidence for concern over carcinogenic, teratogenic, or mutagenic effects of caffeine in man at the observed levels of intake (between 2.0 and $4.5 \mathrm{mg} / \mathrm{kg} /$ day) and that human epidemiological studies provided no evidence for any association between coffee consumption and congenital defects. Most evidence indeed supports a lack of substantial relation between caffeine intake, as measured by coffee consumption, and various 
types of cancer, including gastric cancer [424], renal cancer [425], breast cancer [426,427] and colorectal cancer [428]. In 2016, IARC [294] re-evaluated studies investigating the association between coffee consumption and cancer. For this re-evaluation, a much larger database of prospective cohort and population-based case-control studies that controlled adequately potential confounders, including tobacco and alcohol consumption, was available. For bladder cancer, there was no consistent evidence of association with coffee drinking. In several studies, relative risks were increased in men but were null or decreased in women, consistent with residual confusion caused by smoking or occupational exposures among men. IARC concluded that positive associations between coffee and bladder cancer reported in some studies could have been due to inadequate control for tobacco smoking, which can be strongly associated with heavy coffee drinking, and, as a result of the re-evaluation, IARC changed coffee classification to no carcinogenicity to humans [294]. In the same evaluation, for endometrial cancer, the five largest cohort studies showed mostly inverse associations with coffee drinking. These inverse associations were also observed in cohort and case-control studies of liver cancer in Asia, Europe, and North America, in several types of studies, which lead IARC in 2016 to acknowledge the protective effect of coffee [294], and suggest that an increase in consumption of one cup of coffee/day (and consequently, an increase in caffeine intake of about 50-150 mg/day) was associated with reduced risk of kidney, breast, buccal and pharyngeal, colorectal, endometrial, esophageal, leukemic, pancreatic, and prostate cancers [429-431] and, therefore, regular caffeine intake does not seem to be associated with increased risk of cancer when considering whole coffee consumption. Additional studies on this topic are presented in Table 4.

\subsection{Caffeine Withdrawal Syndrome}

It has been widely experienced that the sudden cessation of regular caffeine ingestion produces specific interrelated symptoms [432,433], which are named caffeine withdrawal syndrome as stated by the Diagnostic and Statistical Manual of Mental Disorders of the American Psychiatric Association (APA) [434]. Characteristic symptoms of caffeine-withdrawal include headache, drowsiness, lethargy, fatigue, work difficulty (decreased motivation for work and impaired concentration), decreased wellbeing (including decreased self-confidence and increased irritability), fall in blood pressure and rise in cerebral blood flow $[432,433,435]$. These are opposite sensations to those obtained after caffeine consumption. Withdrawal symptoms generally begin about 12 to $24 \mathrm{~h}$ after cessation of caffeine consumption and reach a peak after 20 to $48 \mathrm{~h}$. However, in some individuals, these symptoms can appear within only 3 to $6 \mathrm{~h}$ and can last for a week [316]. Thus, even a short abstinence equivalent to missing the morning cup of coffee can lead to significant unpleasant effects $[436,437]$. The syndrome is probably specifically due to the discontinuation of caffeine intake because it persists in spite of analgesic consumption [112] and is reversed by caffeine ingestion [438]. The fact is that daily consumption of caffeine can result in physical dependence and the removal of caffeine causes withdrawal symptoms, irrespective of the pattern of intake across the day [435] and of small (129 mg: one to two cups of coffee) or large (2548 mg: 20-30 cups of coffee) amounts of caffeine ingested [432,437,438]. Caffeine withdrawal syndrome can be avoided if caffeine ingestion decreases slowly.

Slow caffeine metabolizers are less likely to experience sedation on withdrawal or onset of anxiety on resumption. This is in accordance with the general principle that slow reduction minimizes withdrawal symptoms [439]. Moreover, slow metabolizers are likely to drink less coffee and less frequently, which also decreases withdrawal syndrome probability.

Withdrawal symptoms have also been reported in newborns whose mothers were heavy coffee drinkers during pregnancy. These infants displayed irritability, high emotivity, and even vomiting. Symptoms begin at birth and spontaneously disappear after a few days [440]. Caffeine withdrawal may also occur in children who largely consume soft drinks [441].

Despite the described withdrawal symptoms, according to the Diagnostic and Statistical Manual of Mental Disorders, (by APA) [434] caffeine is not present in the category of substances classified as causing "substance dependence", since the substance does not cause the severity of withdrawal or 
harmful drug-seeking behaviors as street drugs or alcohol and these symptoms are easily and reliably reversed by ingestion of caffeine.

Table 4. Complementary studies on the potential adverse effects of caffeine on health.

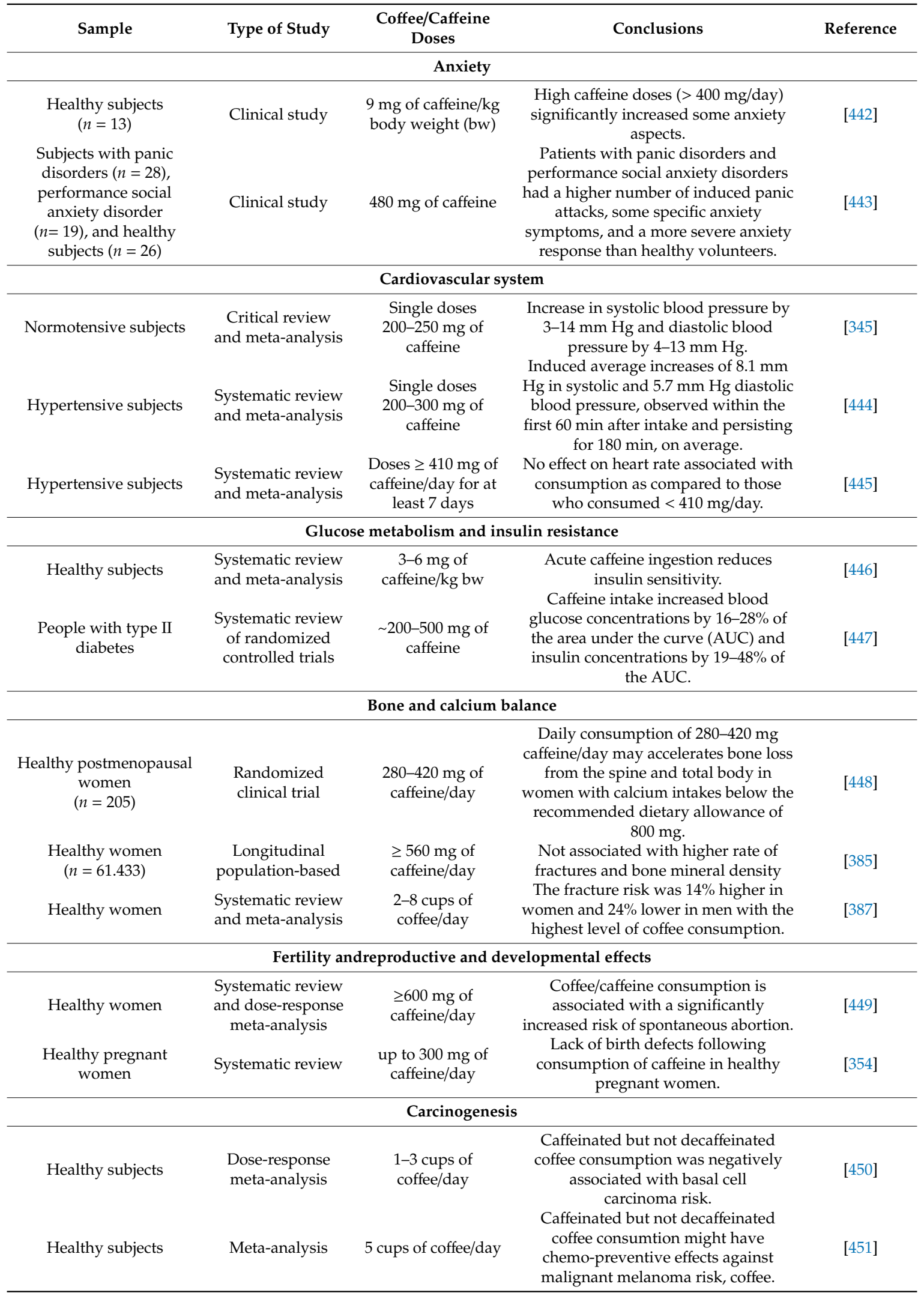




\section{Maximum Caffeine Intake Recommendations}

Because of the high caffeine consumption worldwide, continuous research on potential health effects and on safety aspects has been performed. However, there is currently no recognized reference standard for caffeine consumption, such as an acceptable daily intake (ADI) [452]. A number of assessments have been made around the world, and exposure limits have been adopted for different population groups. Some of the most important ones are presented in Table 5.

Individuals that do not consume caffeine daily are at greater risk of negative physiological effects than the habitual consumers [127]. In the same way, for those who are highly sensitive to the stimulating effects of caffeine, it is hard to determine the safety limit for its consumption [453]. Some slow metabolizers called popularly "ultra-sensitive", can be over-stimulated by the delay in caffeine metabolization and clearance in the body. Moreover, individual differences in responses to caffeine may occur not only at the metabolic (pharmacokinetic) level but also at the drug-receptor (pharmacodynamic) level and they can contribute to the quality and magnitude of direct physiological effects and as a consequence to caffeine consumption. Additional factors are age, use of other drugs and circadian factors [122]. The biological mechanisms of these possible sources of variation involve interactions at multiple sites with the enzymes that break down caffeine in the liver, as well as receptors in the brain that are affected by caffeine [454]. For these reasons, the exact amount of caffeine necessary to produce adverse effects varies from person to person depending on their sensitivity to caffeine [453] and therefore caffeinated beverages should be consumed by these individuals with caution, until a person understands how it interacts with his/her particular genetic structure and health profile [455]. If willing to consume caffeine, ultra-sensitive consumers should try small amounts until they find the amount appropriate or acceptable for them, offering the wellbeing sensation without causing side-effects. For these people, decaffeinated coffee, which still contains residual amounts of caffeine, may be more appropriate.

Commenting on adolescents and children, a study from The University Children's Hospital in Zurich showed that caffeine can interfere with children and teenagers' (aged 10-16 years, $n=32$ ) sleep, possibly hindering proper brain development, and, therefore, limiting caffeine intake was recommended [456]. Moreover, recently, EFSA recommended no consumption of caffeine for children under 12 months [126] and this involves no consumption of all caffeine-containing drinks and foods, such as chocolate drinks, maté, Camelia sinensis teas, and soft drinks, which are often offered by parents.

Attention deficit hyperactivity disorder (ADHD) is one of the most common children's mental health conditions. It involves symptoms of inattention or impulsivity and hyperactivity that lead to behavioral impairments [457]. Many studies have investigated the possible role of caffeine in ADHD. In an animal model study using rats, caffeine restored the function of dopamine as a neurotransmitter in the brain [457]. It is also known that being a vasoconstrictor, caffeine can mimic ADHD medications, such as amphetamine, that also constricts blood vessels and increase concentration $[458,459]$. Notwithstanding the fact that caffeine appears to be beneficial for some children (and also adults) with ADHD, lack of adverse effects is not guaranteed. Overconsumption should be avoided in children, especially on a regular basis and over a long period of time. It is noteworthy mentioning that in some Latin American producing countries, such as Brazil and Colombia, for example, people start drinking coffee with milk early in childhood. In Brazil, a project to stimulate the children's coffee and milk consumption was launched in 2007 and continues to exist to date [460]. Such a small quantity ( $20 \mathrm{~mL}$ coffee per $200 \mathrm{~mL}$ cup) is supposed to be safe and has helped increase attention and learning capacity of children and teenagers in these countries. While limiting caffeine to teenagers to a great extent would be ideal, due to cultural habits and to the increasing demands placed on this age group regarding school, sports, and even work in some places, caffeine consumption is becoming more common among them. According to the American Academy of Pediatrics [461], for all the above reasons and because of possible unknown medical conditions, developing teens should consume no more than $100 \mathrm{mg}$ of caffeine daily. 
Table 5. Caffeine intake safety limit for different age groups recommended by studies and regulatory agencies around the world.

\begin{tabular}{|c|c|c|}
\hline Agency or Study & $\begin{array}{c}\text { Safe Limit of Caffeine } \\
\text { Consumption (mg/day or } \\
\mathrm{mg} / \mathrm{kg} \text { Body Weight - bw/day) }\end{array}$ & $\begin{array}{l}\text { Equivalent to } \\
\text { (Approximately) }\end{array}$ \\
\hline \multicolumn{3}{|c|}{ Adults } \\
\hline $\begin{array}{c}\text { USA: Nawrot et al. [232] } \\
\text { Canada: Health Canada [462] } \\
\text { South Korea: Korean Food and } \\
\text { Drug Administration [463] } \\
\text { Belgium: Belgium Superior } \\
\text { Health Council [325] } \\
\text { Europe: European Food Safety } \\
\text { Authority [126] }\end{array}$ & $400 \mathrm{mg} /$ day & $\begin{array}{c}\text { 1cup of } 100 \mathrm{~mL} \text { espresso coffee }+2 \text { cups of } \\
100 \mathrm{~mL} \text { manual dripped coffee or } \\
6 \text { cups of } 100 \mathrm{~mL} \text { manual dripped coffee or } \\
3 \text { cups of } 100 \mathrm{~mL} \text { French press coffee }+1 \text { cup } \\
100 \mathrm{~mL} \text { cold brewing coffee }\end{array}$ \\
\hline $\begin{array}{c}\text { Europe: European Food Safety } \\
\text { Authority [126] }\end{array}$ & Single doses of up to $200 \mathrm{mg}$ & $\begin{array}{c}3 \text { cups of } 100 \mathrm{~mL} \text { manual dripped coffee or } \\
1 \text { cup of } 100 \mathrm{~mL} \text { soluble coffee }+1 \text { cup } 100 \mathrm{~mL} \\
\text { cold brewing coffee or } \\
2 \text { cups of } 100 \mathrm{~mL} \text { aero press coffee }+1 \text { cup of } \\
100 \mathrm{~mL} \text { infusion coffee bag }\end{array}$ \\
\hline \multicolumn{3}{|c|}{ Reproductive-aged women } \\
\hline $\begin{array}{l}\text { International Life Science } \\
\text { Institute (ILSI) [464] }\end{array}$ & Less than 5 to $6 \mathrm{mg} / \mathrm{kg}$ bw/day & $\begin{array}{l}\text { (amounts estimated for a } 70 \mathrm{~kg} \text { bw woman) } \\
\text { 1cup of } 100 \mathrm{~mL} \text { espresso coffee }+1 \text { cup of } \\
100 \mathrm{~mL} \text { French press coffee or } \\
2 \text { cups of } 100 \mathrm{~mL} \text { mocha coffee }\end{array}$ \\
\hline \multicolumn{3}{|c|}{ Pregnant and lactating woman } \\
\hline $\begin{array}{c}\text { USA: Nawrot et al. [232] } \\
\text { New Zealand: New Zealand } \\
\text { Ministry of Health [452] } \\
\text { South Korea: Korean Food and } \\
\text { Drug Administration [463] } \\
\text { Belgium: Belgium Superior } \\
\text { Health Council [325] }\end{array}$ & $300 \mathrm{mg} /$ day & $\begin{array}{c}1 \text { cup of } 100 \mathrm{~mL} \text { espresso coffee }+1 \text { cup of } \\
100 \mathrm{~mL} \text { dripped coffee or } \\
2 \text { cups of } 100 \text { mL mocha coffee or } \\
2 \text { cups of } 100 \mathrm{~mL} \text { electric dripper coffee }+ \\
1 \text { cup } 100 \mathrm{~mL} \text { ready to drink coffee beverage }\end{array}$ \\
\hline $\begin{array}{l}\text { United Kingdom: UK Food } \\
\text { Standard Agency [465] } \\
\text { Europe: European Food Safety } \\
\text { Authority [126] }\end{array}$ & $200 \mathrm{mg} /$ day & $\begin{array}{c}3 \text { cups of } 100 \mathrm{~mL} \text { manual dripped coffee or } \\
1 \text { cup of } 100 \mathrm{~mL} \text { soluble coffee }+1 \text { cup } 100 \mathrm{~mL} \\
\text { cold brewing coffee or } \\
2 \text { cups of } 100 \mathrm{~mL} \text { aero press coffee }+1 \text { cup of } \\
100 \mathrm{~mL} \text { infusion coffee bag }\end{array}$ \\
\hline \multicolumn{3}{|c|}{ Children } \\
\hline $\begin{array}{c}\text { USA: Nawrot et al. [232] } \\
\text { Canada: Health Canada [462] } \\
\text { South Korea: Korean Food and } \\
\text { Drug Administration [463] } \\
\text { Belgium: Belgium Superior } \\
\text { Health Council [325] }\end{array}$ & $<2.5 \mathrm{mg} / \mathrm{kg}$ bw/day & $\begin{array}{l}\text { (amounts estimated for a child a 5-8-year-old, } \\
\text { with } 22 \mathrm{~kg} \text { bw) } \\
1 \text { cup of } 100 \mathrm{~mL} \text { manual dripped coffee or } \\
1 \text { cup of } 100 \mathrm{~mL} \text { ready to drink coffee beverage }\end{array}$ \\
\hline UK: Knight et al. [466] & $45 \mathrm{mg} /$ day (up to 4 years) & $\begin{array}{l}1 \text { cup of } 50 \mathrm{~mL} \text { cold brewing coffee or } \\
1 \text { cup of } 75 \mathrm{~mL} \text { of manual dripped coffee }\end{array}$ \\
\hline $\begin{array}{c}\text { Europe: European Food Safety } \\
\text { Authority [126] }\end{array}$ & 95 mg/day (aged 5-12 years) & $\begin{array}{c}1 \text { cup of } 100 \mathrm{~mL} \text { manual dripped coffee }+ \\
1 \text { cup of } 50 \mathrm{~mL} \text { ready to drink coffee beverage } \\
\text { (amounts estimated for a 5-8-year-old child, } \\
\text { with } 22 \mathrm{~kg} \mathrm{bw} \text { ) } \\
1 \text { cup of } 100 \mathrm{~mL} \text { manual dripped coffee or } \\
1 \text { cup of } 100 \mathrm{~mL} \text { ready to drink coffee beverage }\end{array}$ \\
\hline
\end{tabular}

\section{Concluding Remarks}

In the present review, reports on the contents of caffeine in coffee seeds, commercial ground roasted coffees, instant coffees, and brews were summarized with focus on the variability of caffeine content in brews due to cultural habits, which are reflected in the blend composition, extraction 
methods, and proportion of powder/water used for brews preparation. Lower amounts of caffeine in coffee can be obtained by decaffeination processes and low-caffeine cultivars.

Caffeine intake varies significantly considering different types of beverages commonly consumed in the various cultures and population groups around the world. Coffee typically contains more caffeine than most other beverages and is widely and frequently consumed. Thus, it contributes significantly to overall caffeine consumption in populations, particularly in adults and the elderly. Considering the widespread caffeine consumption around the world, some assessments have been made in order to establish the maximum safe consumption limit for different population groups. In this case, the inclusion of caffeine on product labels may prevent its unsafe consumption.

A number of studies have demonstrated that caffeine is rapidly absorbed and extensively metabolized mainly in the liver by CYP1A2, which is polymorphically distributed in human populations, causing a considerable difference in clearance time and sensitivity of caffeine's acute effect in the body and this is likely to be an issue that warrants further investigation, regarding health outcomes. Regarding the complexation between caffeine and chlorogenic acids, the bioacessibility and health effects of these complexes are unknown. Considering that plain caffeine and caffeine from coffee were reported to exert similar stimulating effects [127], it is more probable that caffeine is not unbound during digestion and that these complexes are not absorbed. If absorbed, it is probable that they do not bind adenosine receptors. If not absorbed, it is possible that such complexes could exert an antioxidative effect in the digestive system, as it occurs when chlorogenic acids are bound to melanoidins. This subject deserves a thorough investigation.

Caffeine has been the subject of extensive research for its long history of use and elevated consumption worldwide both in natural foods and in medicines. The combined physiological and psychological impacts of caffeine intake depend mainly on the individual genotype and on the pattern and the degree of exposure to the substance. It must also be noted that most mechanistic explanations on caffeine's effects have been derived from acute administration to fasting subjects submitted to a period of caffeine abstinence in order to ensure low plasma caffeine concentrations. It is thus difficult to extrapolate the results to the usual pattern of caffeine consumption, given that most people consume it at different intervals throughout the day and over periods of years. Controversies regarding caffeine's benefits and risks still exist, but reliable evidence is becoming available supporting its health promoting potential when moderate amounts are consumed.

Funding: This research received no external funding other than the scholarships cited bellow.

Acknowledgments: The authors would like to acknowledge the scholarships provided by the National Council for Scientific and Technological Development (CNPq, Brazil reg.\# 309091/2016-0) and the Rio de Janeiro State Research Support Foundation (FAPERJ: E-02/2017\# 234092).

Conflicts of Interest: The authors declare no conflicts of interest.

\section{References}

1. Fredholm, B.B. Notes on the history of caffeine use. In Methylxanthines; Fredholm, B.B., Ed.; Springer: New York, NY, USA, 2011; pp. 1-9.

2. Tarka, S.M.; Hurst, W.J. Introduction to the chemistry, isolation, and biosynthesis of methylxanthines. In Caffeine; Spiller, G.A., Ed.; CRC Press: Boca Raton, FL, USA, 1998; pp. 1-12.

3. Zulak, K.G.; Liscome, D.K.; Ashihara, H.; Facchini, P.J. Alkaloids. In Plant Secondary Metabolites: Occurrence Structure, and Role in the Human Diet; Crozier, A., Clifford, M.N., Ashihara, H., Eds.; Blackwell: Oxford, UK, 2006; pp. 102-136.

4. Lima, J.P.; Farah, A. Caffeine and minor methylxanthines in coffee. In Coffee: Consumption and Health Implications; Farah, A., Ed.; Royal Society of Chemistry: London, UK, 2019; ISBN 978-1782620044.

5. Pauwels, R.A. Global strategy for the diagnosis, management, and prevention of chronic obstructive pulmonary disease. NHLBI/WHO Global Initiative for Chronic Obstructive Lung Disease (GOLD) Workshop summary. Am. J. Respir. Crit. Care Med. 2001, 163, 1256-1276. [CrossRef] [PubMed] 
6. Ashihara, H.; Crozier, A. Biosynthesis and metabolism of caffeine and related purine alkaloids in plants. Adv. Bot. Res. 1999, 30, 117-205. [CrossRef]

7. Chow, T.M.; Benowitz, N.L. Caffeine and coffee: Effects on health and cardiovascular disease. Comp. Biochem. Physiol. 1994, 109, 173-189. [CrossRef]

8. von Goethe, J.W.; von Biedermann, F.W. Hauswirtschaftlichen Briefen; von Goethe, J.W., von Biedermann, F.W., Eds.; Goethes Gespräche, Nachträge: Leipzig, Germany, 1896; pp. 89-96.

9. Weinberg, A.; Bealer, B.K. (Eds.) The World of Caffeine: The Science and Culture of the World's Most Popular Drug; Routledge: New York, NY, USA, 2001; p. 394.

10. Meusinger, R. Solution to spectroscopy challenge 13. Caffeine. Anal Bioanal. Chem. 2009, 393, 1381-1382. [CrossRef] [PubMed]

11. Fischer, E. Ueber das Caffeïn. Ber. Dtsch.Chem. Ges. 1881, 14, 1905-1915. [CrossRef]

12. Fischer, E. Ueber das Caffeïn. Ber. Dtsch. Chem. Ges. 1881, 14, 637-644. [CrossRef]

13. Vitzthum, O.G.; Werkhoff, P.Z. Steam volatile aroma constituents of roasted coffee: Neutral fraction. Lebensm Unters Forsch. 1976, 160, 277-291. [CrossRef]

14. Arnaud, M.J. Encyclopedia of Human Nutrition's; Caballero, B., Allen, L., Prentice, A., Eds.; Elsevier Academic Press: Cambridge, UK, 2005; p. 247.

15. Belay, A.; Ture, K.; Redi, M.; Asfaw, A. Measurement of caffeine in coffee beans with UV-Vis spectrometer. Food Chem. 2008, 108, 310-315. [CrossRef]

16. Holiday, E.R. The characteristic absorption of ultra-violet radiation by certain purines. Biochem. J. 1930, 24, 619-625. [CrossRef]

17. Association of Official Agricultural Chemists in Official and Tentative Methods of Analysis; George Banta Publishing: Washington, DC, USA, 1945.

18. De Maria, C.A.B.; Moreira, R.F.A. Cafeína: Revisão sobre métodos de análise. Quim. Nova 2007, 30, 99-105. [CrossRef]

19. Hartley, W.N. Observations on chemical structure and those physical properties on which the theory of color is based. J. Chem. Soc. Trans. 1905, 87, 1822-1831. [CrossRef]

20. Ishler, N.H.; Finucane, T.P.; Borker, E. Rapid spectrophotometric determination of caffeine. Anal. Chem. 1948, 20, 1162-1166. [CrossRef]

21. López-Martínez, L.; López-de-Alba, P.L.; García-Campos, R.; De León-Rodríguez, L.M. Simultaneous determination of methylxanthines in coffees and teas by UV-Vis spectrophotometry and partial least squares. Anal. Chim. Acta 2003, 493, 83-94. [CrossRef]

22. Brown, S.R.; Cann, P.A.; Read, N.W. Effect of coffee on distal colon function. Gut 1990, 31, 450-453. [CrossRef] [PubMed]

23. Murgia, E.; Richards, P.; Walton, H.F. Liquid chromatography of xanthine's, analgesic drugs and coffee. J. Chromatogr. 1973, 87, 523-533. [CrossRef]

24. Bispo, M.S.; Veloso, M.C.C.; Pinheiro, H.L.C.; de Oliveira, R.F.S.; Reis, J.O.N.; de Andrade, J.B. Simultaneous determination of caffeine, theobromine, and theophylline by high-performance liquid chromatography. J. Chromatogr. Sci. 2002, 40, 45-48. [CrossRef] [PubMed]

25. Farah, A.; de Paulis, T.; Trugo, L.C.; Martin, P.R. Chlorogenic acids and lactones in regular and water-decaffeinated arabica coffees. J. Agric. Food Chem. 2006, 54, 374-381. [CrossRef]

26. Perrone, D.; Donangelo, C.M.; Farah, A. Fast simultaneous analysis of caffeine, trigonelline, nicotinic acid and sucrose in coffee by liquid chromatography-mass spectrometry. Food Chem. 2008, 110, 1030-1035. [CrossRef] [PubMed]

27. Trugo, L.C.; Macrae, R.; Dick, J. Determination of purine alkaloids and trigonelline in instant coffee and other beverages using high performance liquid chromatography. J. Sci. Food Agric. 1983, 34, 300-306. [CrossRef]

28. Casal, S.; Oliveira, M.B.; Ferreira, M.A. Development of an HPLC/diode-array detector method for simultaneous determination of trigonelline, nicotinic acid, and caffeine in coffee. Food Chem. 1998, 21, 3187-3195. [CrossRef]

29. Casal, S.; Oliveira, M.B.; Ferreira, M.A. Discriminate analysis of roasted coffee varieties for trigonelline, nicotinic acid, and caffeine content. J. Agric. Food Chem. 2000, 48, 3420-3424. [CrossRef] [PubMed]

30. Redivo, L.; Stredanský, M.; De Angelis, E.; Navarini, L.; Resmini, M.; Švorc, Ĺ. Bare carbon electrodes as simple and efficient sensors for the quantification of caffeine in commercial beverages. R. Soc. Open Sci. 2018, 5, 172146. [CrossRef] [PubMed] 
31. Perrone, D.; Farah, A. Caffeine: Chemistry, Analysis, Function and Effects; Preedy, V., Ed.; Royal Society of Chemistry: Cambridge, UK, 2012; p. 97. ISBN -9781849733670.

32. Briandet, R.; Kemsley, E.K.; Wilson, R.H. Discrimination of arabica and robusta in instant coffees by Fourier transform infrared spectroscopy and chemometrics. J. Agric. Food Chem. 1996, 44, 170-174. [CrossRef]

33. Bouhsain, Z.; Garrigues, S.; de la Guardia, M. Clean method for the simultaneous determination of propyphenazone and caffeine in pharmaceuticals by flow injection Fourier transform infrared spectrometry. Analyst 1997, 122, 441-445. [CrossRef] [PubMed]

34. Harborne, B.J. Introduction to Ecological Biochemistry; Harborne, J.B., Ed.; Elsevier Academic Press: Cambridge, UK, 1993; p. 1. ISBN 9780080918587.

35. Hewavitharanage, P.; Karunaratne, S.; Kumar, N.S. Effect of caffeine on shot-hole borer beetle (Xyleborusfornicatus) of tea (Camellia sinensis). Phytochemistry 1999, 51, 35-41. [CrossRef]

36. Waller, G.R. Biochemical frontiers of allelopathy. Biol. Plant. 1989, 31, 418-447. [CrossRef]

37. Mazzafera, P.; Carvalho, A. Breeding for low seed caffeine content of coffee (Coffea L.) by interspecific hybridization. Euphytica 1992, 59, 55-60. [CrossRef]

38. Macrae, R. Coffee Chemistry; Clarke, R.J., Macrae, R., Eds.; Elsevier: New York, NY, USA, 1985; p. 115.

39. Farah, A.; Monteiro, M.C.; Calado, V.; Franca, A.S.; Trugo, L.C. Correlation between cup quality and chemical attributes of Brazilian coffee. Food Chem. 2006, 98, 373-380. [CrossRef]

40. Duarte, G.S.; Pereira, A.A.; Farah, A. Chlorogenic acids and other relevant compounds in Brazilian coffees processed by semi-dry and wet post-harvesting methods. Food Chem. 2010, 118, 851-855. [CrossRef]

41. Alonso-Salces, R.M.; Serra, F.; Reniero, F.; Rolyheberger, A. Botanical and geographical characterization of green coffee (Coffea arabica and Coffea canephora): Chemometric evaluation of phenolic and methylxanthine contents. J. Agric. Food Chem. 2009, 57, 4224-4235. [CrossRef]

42. Clifford, M.N.; Kazi, T. The influence of coffee bean maturity on the content of chlorogenic acids, caffeine and trigonelline. Food Chem. 1987, 26, 59-69. [CrossRef]

43. Clifford, M.N. Coffee: Botany, Biochemistry and Production of Beans and Beverage; Clifford, M.N., Wilson, K.C., Eds.; Springer: New York, NY, USA, 1985; p. 305.

44. Mazzafera, P.; Crozier, A.; Magalhães, A.C. Caffeine metabolism in Coffea arabica and other species of coffee. Phytochemistry 1991, 30, 3913-3916. [CrossRef]

45. Clifford, M.N.; Ramirez-Martinez, J.R. Phenols and caffeine in wet-processed coffee beans and coffee pulp. Food Chem. 1991, 40, 35-42. [CrossRef]

46. Mazzafera, P.; Carvalho, A.; Fazuoli, L.C.; Medina Filho, H.P. Variabilidade do teor de cafeína em sementes de café. Turrialba 1992, 42, 231-237.

47. Ky, C.L.; Louarn, J.; Guyot, B.; Dussert, S.; Hamon, S.; Noirot, M. Caffeine, trigonelline, chlorogenic acids and sucrose diversity in wild Coffea arabica L. and Coffea canephora P. accessions. Food Chem. 2001, 75, 223-230. [CrossRef]

48. Mazzafera, P.; Silvarolla, M.B. Caffeine content variation in single green Arabica coffee seeds. Seed Sci. Res. 2010, 20, 163-167. [CrossRef]

49. de Souza, R.M.N.; Benassi, M.T. Discrimination of commercial roasted and ground coffees according to chemical composition. J. Braz. Chem. Soc. 2012, 23, 1347-1354. [CrossRef]

50. Hečimović, I.; Belščak-Cvitanović, A.; Horžić, D.; Komes, D. Comparative study of polyphenols and caffeine in different coffee varieties affected by the degree of roasting. Food Chem. 2011, 129, 991-1000. [CrossRef]

51. Mehari, B.; Redi-Abshiro, M.; Chandravanshi, B.S. Simultaneous determination of alkaloids in green coffee beans from Ethiopia: Chemometric evaluation of geographical origin. Food Anal. Methods 2016, 9, 1627-1637. [CrossRef]

52. Babova, O.; Occhipinti, A.; Maffei, M.E. Chemical partitioning and antioxidant capacity of green coffee (Coffea arabica and Coffea canephora) of different geographical origin. Phytochemistry 2016, 123, 33-39. [CrossRef]

53. Martín, M.J.; Pablos, F.; Gonzalez, A.G. Discrimination between arabica and robusta green coffee varieties according to their chemical composition. Talanta 1998, 46, 1259-1264. [CrossRef]

54. Nebesny, E.; Budryn, G. Antioxidative activity of green and roasted coffee beans as influenced by convection and microwave roasting methods and content of certain compounds. Eur. Food Res. Technol. 2003, 217, 157-163. [CrossRef]

55. Campa, C.; Doulbeau, S.; Dussert, S.; Hamon, S.; Noirot, M. Qualitative relationship between caffeine and chlorogenic acid contents among wild Coffea species. Food Chem. 2005, 93, 135-139. [CrossRef] 
56. Ramalakshmi, K.; Kubra, R.; Rao, L.J.M. Physicochemical characteristics of green coffee: Comparison of graded and defective beans. J. Food Sci. 2007, 72, 333-337. [CrossRef]

57. Farah, A. Nutritional and health aspects of coffee. In Coffee: Emerging Health Effects and Disease Prevention; Chu, Y.-F., Ed.; IFT Press and John Wiley \& Sons: New York, NY, USA, 2012; p. 21.

58. Burdan, F. Coffee in Health and Disease Prevention; Preedy, V.R., Ed.; Elsevier: Cambridge, UK, $2015 ;$ p. 823. ISBN 9780124167162.

59. Fujimori, N.; Ashihara, H. Biosynthesis of theobromine and caffeine in developing leaves of Coffea arabica. Phytochemistry 1994, 36, 1359-1361. [CrossRef]

60. Payen, S. Undersuchung des Kaffees. Annalen 1846, 60, 286-294.

61. Sondheimer, E.; Szymanski, C.D.; Corse, J.W. Coffee constituents, isolation of chlorogenic acid and its isomers from coffee. J. Agric. Food Chem. 1961, 9, 146-149. [CrossRef]

62. D'Amelio, N.; Fontanive, L.; Uggeri, F.; Suggi-Liverani, F.; Navarini, L. NMR reinvestigation of the caffeine-chlorogenate complex in aqueous solution and in coffee brews. Food Biophys. 2009, 4, 321-330. [CrossRef]

63. D'Amelio, N.; Papamokos, G.; Dreyer, J.; Carloni, P.; Navarini, L. NMR studies of hetero-association of caffeine with di-O-caffeoylquinic acid isomers in aqueous solution. Food Biophys. 2015, 10, 235-243. [CrossRef]

64. Horman, I.; Viani, R. The nature and complexation of the caffeine-chlorogenate complex of coffee. J. Food Sci. 1972, 37, 925-927. [CrossRef]

65. Anthony, F.; Noirot, M.; Clifford, M.N. Biochemical diversity in the genus Coffea L.: Chlorogenic acids, caffeine and mozambioside contents. Genet. Resour. Crop Evol. 1993, 40, 61-70. [CrossRef]

66. Teixeira, A.A.; Brando, C.H.; Thomaziello, R.A.; Teixeira, R.; Drying, R. Espresso Coffee: The Science of Quality; Illy, A., Viani, R., Eds.; Elsevier Academic Press: San Diego, CA, USA, 1995; p. 91.

67. Trugo, L.C.; Macrae, R. Chlorogenic acid composition of instant coffees. Analyst 1984, 109, 263-266. [CrossRef] [PubMed]

68. Balyaya, K.J.; Clifford, M.N. Chlorogenic acids and caffeine contents of monsooned Indian Arabica and Robusta coffees compared with wet and dry processed coffees from the same geographic area. In Proceedings of the 16th of the International Conference on Coffee Science, Kyoto, Japan, 1995; p. 316.

69. Leloup, V.; Louvrier, A.; Liardon, R. Degradation mechanisms of chlorogenic acids during roasting. In Proceedings of the 16th of the International Conference on Coffee Science, Kyoto, Japan, 1995; p. 192.

70. Franca, A.S.; Oliveira, L.S.; Mendonça, C.F.; Silva, X.A. Physical and chemical attributes of defective crude and roasted coffee beans. Food Chem. 2005, 90, 84-89. [CrossRef]

71. Toci, A.T.; Farah, A. Contents of chlorogenic acids, caffeine, trigoneline and sucrose in Brazilian defective deeds. In Proceedings of the 23th of the International Conference on Coffee Science, Bali, Indonesia, 2011; p. 260.

72. Bicho, N.C.; Leitão, E.R.; Ramalho, J.C.; Lidon, F.C. Identification of chemical clusters discriminators of the roast degree in Arabica and Robusta coffee beans. Eur. Food Res. Technol. 2011, 233, 303-311. [CrossRef]

73. Pilipczuk, T.; Kusznierewicz, B.; Zielińska, D.; Bartoszek, A. The influence of roasting and additional processing on the content of bioactive components in special purpose coffees. J. Food Sci. Technol. 2014, 52, 5736-5744. [CrossRef] [PubMed]

74. Kitzberger, C.S.G.; Scholz, M.B.; Benassi, M.T. Bioactive compounds content in roasted coffee from traditional and modern Coffea arabica cultivars grown under the same edapho-climatic conditions. Food Res. Int. 2014, 61,61-66. [CrossRef]

75. Monteiro, M.C.; Trugo, L.C. Determination of bioactive compounds in brazilian roasted coffees. Quím. Nova 2005, 28, 637-641. [CrossRef]

76. Fujioka, K.; Shibamoto, T. Chlorogenic acid and caffeine contents in various commercial brewed coffees. Food Chem. 2008, 106, 217-221. [CrossRef]

77. Santos, J.R.; Rangel, A.O.S.S. Development of a chromatographic low-pressure flow injection system: Application to the analysis of methylxanthines in coffee. Anal. Chim. Acta 2012, 715, 57-63. [CrossRef]

78. dePaula, J.; Farah, A. Methylxanthines in stimulant foods and beverages commonly consumed in Brazil. J. Food Compos. Anal. 2019. [CrossRef]

79. Pérez-Hernández, L.M.; Chávez-Quiroz, K.; Medina-Juárez, L.A.; Meza, N.G. Phenolic characterization, melanoidins, and antioxidant activity of some commercial coffees from Coffea arabica and Coffea canephora. J. Mex. Chem. Soc. 2012, 56, 430-435. 
80. Vignoli, J.A.; Bassoli, D.G.; Benassi, M.T. Antioxidant activity, polyphenols, caffeine and melanoidins in soluble coffee: The influence of processing conditions and raw material. Food Chem. 2011, 124, 863-868. [CrossRef]

81. Nogueira, M.; Trugo, L.C. Distribuição de isômeros de ácido clorogênico e teores de cafeína e trigonelina em cafés solúveis brasileiros. Cienc. Tecnol. Aliment. 2003, 23, 296-299. [CrossRef]

82. Wanyika, H.N.; Gatebe, E.G.; Gitu, L.M.; Ngumba, E.K.; Maritim, C.W. Determination of caffeine content of tea and instant coffee brands found in the Kenyan market. Afr. J. Food Sci. 2010, 4, 353-358.

83. Del Campo, G.; Berregi, I.; Caracena, R.; Zuriarrain, J. Quantitative determination of caffeine, formic acid, trigonelline and 5-(hydroxymethyl)furfural in soluble coffees by 1H NMR spectrometry. Talanta 2010, 81, 367-371. [CrossRef] [PubMed]

84. Farah, A. Nutritional and health effects of coffee. In Achieving Sustainable Cultivation of Coffee; Lashermes, P., Ed.; Burleigh Dodds Science Publishing: Cambridge, UK, 2017; pp. 1-31. ISBN 978-1-78676-152-1.

85. McCusker, R.R.; Goldberger, B.A.; Cone, E.J. Caffeine content of specialty coffees. J. Anal. Toxicol. 2003, 27, 520-522. [CrossRef] [PubMed]

86. Jeon, J.S.; Kim, H.T.; Jeong, I.H.; Hong, S.R.; Oh, M.S.; Park, K.H.; Shim, J.H.; Abd El-Aty, A.M. Determination of chlorogenic acids and caffeine in homemade brewed coffee prepared under various conditions. J. Chromatogr. B Anal. Technol. Biomed. Life Sci. 2017, 1064, 115-123. [CrossRef]

87. Rodrigues, N.P.; Bragagnolo, N. Identification and quantification of bioactive compounds in coffee brews by HPLC-DAD-MS. J. Food Comp. Anal. 2013, 32, 105-115. [CrossRef]

88. Burg, A.W. Effects of caffeine in the human system. Tea Coffee Trade J. 1975, 147, 40-41.

89. Gilbert, R.M. Caffeine Consumption; Spiller, G.A., Ed.; A. R. Liss Incorporation: New York, NY, USA, 1984; p. 185.

90. Barone, J.J.; Roberts, H.R. Caffeine consumption. Food Chem. Toxicol. 1996, 34, 119-129. [CrossRef]

91. Center for Science in the Public Interest. Available online: http://www.cspinet.org/new/cafchart.htm (accessed on 1 February 2019).

92. Bravo, J.; Juániz, I.; Monente, C.; Caemmererb, B.; Krohb, L.W.; Paz De Peña, M.; Cid, C. Evaluation of spent coffee obtained from the most common coffeemakers as a source of hydrophilic bioactive compounds. J. Agric. Food Chem. 2012, 60, 12565-12573. [CrossRef] [PubMed]

93. Lopez-Galilea, I.; de Peña, M.P.; Cid, C. Correlation of selected constituents with the total antioxidant capacity of coffee beverages: influence of the brewing procedure. J. Agric. Food Chem. 2007, 55, 6110-6117. [CrossRef]

94. Angeloni, G.; Guerrini, L.; Masella, P.; Bellumori, M.; Daluiso, S.; Parenti, A.; Innocenti, M. What kind of coffee do you drink? An investigation on effects of eight different extraction methods. Food Res. Int. 2018. [CrossRef]

95. Maeztu, L.; Andueza, S.; Ibañez, C.; de Peña, M.P.; Bello, J.; Cid, C. Multivariate methods for characterization and classification of espresso coffees from different botanical varieties and types of roast by foam, taste, and mouthfeel. J. Agric. Food Chem. 2001, 49, 4743-4747. [CrossRef] [PubMed]

96. Crozier, T.W.M.; Stalmach, A.; Lean, M.E.J.; Crozier, A. Espresso coffees, caffeine and chlorogenic acid intake: Potential health implications. Food Funct. 2012, 3, 30-33. [CrossRef]

97. Niseteo, T.; Komes, D.; Belščak-Cvitanović, A.; Horžić, D.; Budeč, M. Bioactive composition and antioxidant potential of different commonly consumed coffee brews affected by their preparation technique and milk addition. Food Chem. 2012, 134, 1870-1877. [CrossRef] [PubMed]

98. Desbrow, B.; Hughes, R.; Leveritt, M.; Scheelings, P. An examination of consumer exposure to caffeine from retail coffee outlets. Food Chem. Toxicol. 2007, 45, 1588-1592. [CrossRef] [PubMed]

99. Fuller, M.; Rao, N.Z. The effect of time, roasting temperature, and grind size on caffeine and chlorogenic acid concentrations in cold brew coffee. Sci. Rep. 2017, 7, 17979. [CrossRef] [PubMed]

100. Tfouni, S.A.V.; Carreiro, L.B.; Teles, C.R.A.; Furlani, R.P.Z.; Cipolli, K.M.V.A.B.; Camargo, M.C.R. Caffeine and chlorogenic acids intake from coffee brew: Influence of roasting degree and brewing procedure. Int. J. Food Sci. Technol. 2014, 49, 747-752. [CrossRef]

101. Aragão, N.M.D.; Veloso, M.C.C.; Bispo, M.S.; Ferreira, S.L.C.; Andrade, J.B. Multivariate optimization of the experimental conditions for determination of three methylxanthines by reversed-phase high-performance liquid chromatography. Talanta 2005, 67, 1007-1013. [CrossRef]

102. Sereshti, H.; Samadi, S. Rapid and simple determination of caffeine in teas, coffees and eight beverages. Food Chem. 2014, 158, 8-13. [CrossRef] [PubMed] 
103. Farah, A.; Lima, J.P. Consumption of chlorogenic acids through coffee and health implications. Beverages 2019, 5, 11. [CrossRef]

104. National Coffee Association. National Coffee Drinking Trends. 2009. Available online: http://www.ncausa.org (accessed on 5 February 2019).

105. Scientific American. How Is Caffeine Remove to Produce Decaffeinated Coffee? Available online: https: //www.scientificamerican.com/article/how-is-caffeine-removed-t/ (accessed on 9 February 2019).

106. International Trade Centre. Available online: http://www.intracen.org/coffee-guide/the-markets-for-coffee/ demand---Decaffeinated-coffee (accessed on 9 February 2019).

107. European Coffee Federation. Available online: http://www.ecf-coffee.org (accessed on 1 February 2019).

108. United States Department of Agriculture. Available online: https://ndb.nal.usda.gov/ndb (accessed on 1 February 2019).

109. Agência Nacional de Vigilância Sanitária. Available online: http://www.anvisa.gov.br (accessed on 1 February 2019).

110. McCusker, R.R.; Goldberger, B.A.; Cone, E.J. Caffeine content of energy drinks, carbonated sodas, and other beverages. J. Anal. Toxicol. 2006, 30, 112-114. [CrossRef] [PubMed]

111. Ogawa, H.; Ueki, N. Clinical importance of caffeine dependence and abuse. Psychiatry Clin. Neurosci. 2007, 61, 263-268. [CrossRef] [PubMed]

112. Fredholm, B.B.; Battig, K.; Holmén, J.; Nehlig, A.; Zvartau, E.E. Actions of caffeine in the brain with special reference to factors that contribute to its widespread use. Pharmacol. Rev. 1999, 51, 83-133. [PubMed]

113. Smit, H.J.; Rogers, P.J. Effects of 'energy' drinks on mood and mental performance: Critical methodology. Food Qual. Pref. 2002, 13, 317-326. [CrossRef]

114. Arnaud, M.J. Pharmacokinetics and metabolism of natural methylxanthines in animal and man. Handb. Exp. Pharmacol. 2011, 200, 33-91. [CrossRef]

115. Borota, D.; Murray, E.; Keceli, G.; Chang, A.; Watabe, J.M.; Ly, M.; Toscano, J.P.; Yassa, M.A. Post-study caffeine administration enhances memory consolidation in humans. Nat. Neurosci. 2014, 17, 201-203. [CrossRef]

116. Ludwig, I.A.; Clifford, M.N.; Lean, M.E.; Ashihara, H.; Crozier, A. Coffee: Biochemistry and potential impact on health. Food Funct. 2014, 5, 1695-1717. [CrossRef] [PubMed]

117. International Coffee Organization. World Coffee Consumption. Available online: http://www.ico.org (accessed on 1 February 2019).

118. World Atlas. Top 10 Coffee Consuming Nations. Available online: https://www.worldatlas.com/articles/top10-coffee-consuming-nations.html (accessed on 1 February 2019).

119. Clifford, M.N.; Ramirez-Martinez, J.R. Chlorogenic acids and purine alkaloids contents of mate (Ilex paraguariensis) leaf and beverage. Food Chem. 1990, 35, 13-21. [CrossRef]

120. Pelozo, M.I.G.; Cardoso, M.L.C.; de Mello, J.C.P. Spectrophotometric determination of tannins and caffeine in preparations from Paullinia cupana var. sorbilis. Braz. Arch. Biol. Technol. 2008, 51, 447-451. [CrossRef]

121. Vester, J.C.; Koenig, J. Caffeine intake and its sources: A review of national representative studies. Crit. Rev. Food Sci. Nutr. 2018, 58, 1250-1259. [CrossRef] [PubMed]

122. Lima, J.P.; Farah, A. Caffeine Consumption. In Coffee: Consumption and Health Implications; Farah, A., Ed.; Royal Society of Chemistry: London, UK, 2018; ISBN 978-1782620044.

123. Food and Agriculture Organization of the United Nations. Food Balance Sheets; FAO: Rome, Italy, 1995.

124. Mitchell, D.C.; Knight, C.A.; Hockenberry, J.; Teplansky, R.; Hartman, T.J. Beverage caffeine intakes in the U.S. Food Chem. Toxicol. 2014, 63, 136-142. [CrossRef] [PubMed]

125. Mitchell, D.C.; Hockenberry, J.; Teplansky, R.; Hartman, T.J. Assessing dietary exposure to caffeine from beverages in the U.S. population using brand-specific versus category-specific caffeine values. Food Chem. Toxicol. 2015, 80, 247-252. [CrossRef] [PubMed]

126. European Food Safety Authority-(EFSA Panel on Dietetic Products, Nutrition and Allergies). Scientific Opinion on the Safety of Caffeine; European Food Safety Authority: Parma, Italy, 2015.

127. Heckman, M.A.; Weil, J.; De Mejia, E.G. Caffeine (1, 3, 7-trimethylxanthine) in foods: A comprehensive review on consumption, functionality, safety, and regulatory matters. J. Food Sci. 2010, 75, 77-87. [CrossRef] [PubMed]

128. Lima, J.P. Contribuição de alimentos fonte para a ingestão dietética habitual estimada de metilxantinas no Brasil e no município do Rio de Janeiro. Master's Thesis, Instituto de Nutrição, Universidade Federal do Rio de Janeiro, Rio de Janeiro, Brasil, 2014. 
129. Knight, C.A.; Knight, I.; Mitchell, D.C.; Zepp, J.E. Beverage caffeine intake in US consumers and subpopulations of interest: Estimates from the Share of Intake Panel survey. Food Chem. Toxic. 2004, 42, 1923-1930. [CrossRef]

130. Olmos, V.; Bardoni, N.; Ridolfi, A.S.; Villaamil, E.C. Caffeine levels in beverages from Argentina's market: Application to caffeine dietary intake assessment. Food Addit. Contam. Part A 2009, 26, 275-281. [CrossRef]

131. Bizzo, M.L.G.; Farah, A.; Kemp, J.A.; Scancetti, L.B. Highlights in the History of Coffee Science Related to Health. In Coffee and Health Disease Prevention; Preedy, V.R., Ed.; Elsevier: Cambridge, UK, 2015; pp. 11-17, 812. ISBN 9780124167162.

132. Lima, J.P.; Farah, A. Caffeine Metabolism and Health Effects. In Coffee: Consumption and Health Implications; Farah, A., Ed.; Royal Society of Chemistry: London, UK, 2018; ISBN 978-1782620044.

133. Cornish, H.H.; Christman, A.A. A study of the metabolism of theobromine, theophylline, and caffeine in man. J. Biol. Chem. 1957, 228, 315-323. [PubMed]

134. Otomo, T. Changes of caffeine in the animal body. Nichidai Igaku Zasshi 1959, 18, 77-86.

135. Schmidt, G.; Schoyerer, R. Determination of caffeine and its metabolites in urine. Deut. Z. Gesamte Gerichtl. Med. 1966, 57, 402-409.

136. Czok, G.; Schmidt, B.; Lang, K. Influence of nutrition and habituation on the distribution of 8-C14-caffeine in the rat. Klin. Wochenschr 1968, 46, 1055-1059. [CrossRef] [PubMed]

137. Bertoli, M.A.; Dragoni, G.; Rodari, A. Tissue distribution of labeled caffeine in mice. Med. Nucl. Radiobiol. Lat. 1968, 11, 231.

138. Blanchard, J.; Sawers, S.J. The absolute bioavailability of caffeine in man. Eur. J. Clin. Pharmacol. 1983, 24, 93-98. [CrossRef] [PubMed]

139. Lelo, A.; Birkett, D.J.; Robson, R.A.; Miners, J.O. Comparative pharmacokinetics of caffeine and its primary demethylated metabolites paraxanthine, theobromine and theophylline in man. Br. J. Clin. Pharmacol. 1986, 22, 1771-1782. [CrossRef] [PubMed]

140. Mumford, G.K.; Benowitz, N.L.; Evans, S.M.; Kaminski, B.J.; Preston, K.L.; Sannerud, C.A.; Silverman, K.; Griffiths, R.R. Absorption rate of methylxanthines following capsules, cola and chocolate. Eur. J. Clin. Pharmacol. 1996, 51, 319-325. [CrossRef] [PubMed]

141. Kuwazawa, T.; Seno, H.; Lee, X.-P.; Ishii, A.; Watanabe-Suzuki, K.; Sato, K.; Suzuki, O. Extraction of methylxanthines from human body fluids by solid-phase microextraction. Anal. Quim. Acta 1999, 387, 53-60. [CrossRef]

142. Bonati, M.; Latini, R.; Galletti, F.; Young, J.F.; Tognoni, G.; Garattini, S. Caffeine disposition after oral doses. Clin. Pharmacol. Ther. 1982, 32, 98-106. [CrossRef] [PubMed]

143. Krul, C.; Hageman, G. Analysis of urinary caffeine metabolites to assess biotransformation enzyme activities by reversed-phase high-performance liquid chromatography. J. Chromatogr. B Biomed. Sci. Appl. 1998, 709, 27-34. [CrossRef]

144. Parke, D.V. The Biochemistry of Foreign Compounds; Parke, D.V., Ed.; Pergamon Press: London, UK, 1968; p. 139.

145. Perera, V.; Gross, A.S.; McLachlan, A.J. Caffeine and paraxanthine HPLC assay for CYP1A2 phenotype assessment using saliva and plasma. Biom. Chromatogr. 2010, 24, 1136-1144. [CrossRef]

146. Teekachunhatean, S.; Tosri, N.; Rojanasthien, M.; Srichairatanakool, S.; Sangdee, C. Pharmacokinetics of caffeine following a single administration of coffee enema versus oral coffee consumption in healthy male subjects. ISRN Pharmacol. 2013, 4. [CrossRef]

147. Lang, R.; Dieminger, N.; Beusch, A.; Lee, Y.; Dunkel, A.; Suess, B.; Skurk, T.; Wahl, A.; Hauner, H.; Hofman, T. Bioappearance and pharmacokinetics of bioactives upon coffee consumption. Anal. Bioanal. Chem. 2013, 405, 8487-8503. [CrossRef] [PubMed]

148. Martinez-Lopéz, S.; Sarriá, B.; Baeza, G.; Mateos, R.; Bravo-Clemente, L. Pharmacokinetics of caffeine and its metabolites in plasma and urine after consuming a soluble green/roasted coffee blend by healthy subjects. Food Res. Int. 2014, 64, 125-133. [CrossRef] [PubMed]

149. Scheneider, H.; Ma, L.; Glatt, H. Extraction less method for the determination of urinary caffeine metabolites using high-performance liquid chromatography coupled with tandem mass spectrometry. J. Chromatogr. B Analyt. Technol. Biomed. Life Sci. 2003, 789, 227-237. [CrossRef] 
150. Rodopoulos, N.; Norman, A. Assessment of dimethylxanthine formation from caffeine in healthy adults: Comparison between plasma and saliva concentrations and urinary excretion of metabolites. Scand. J. Clin. Lab. Investig. 1996, 56, 259-268. [CrossRef] [PubMed]

151. Rodopoulos, N.; Winsen, O.; Norman, A. Caffeine metabolism in patients with chronic liver disease. Scand. J. Clin. Lab. Investig. 1995, 55, 229-242. [CrossRef]

152. Gilbert, S.G.; Stavric, B.; Klassen, R.D.; Rice, D.C. The fate of chronically consumed caffeine in the monkey (Macaca fascicularis). Fundam. Appl. Toxicol. 1985, 5, 578-587. [CrossRef]

153. Kamimori, G.H.; Karyekar, C.S.; Otterstetter, R.; Cox, D.S.; Balkin, T.J.; Belenky, G.L.; Eddington, N.D. The rate of absorption and relative bioavailability of caffeine administered in chewing gum versus capsules to normal healthy volunteers. Int. J. Pharm. 2002, 234, 159-167. [CrossRef]

154. Cohen, S.; Booth, G.H., Jr. Gastric acid secretion and lower-esophageal-sphincter pressure in response to coffee and caffeine. N. Engl. J. Med. 1975, 293, 897-899. [CrossRef] [PubMed]

155. Kaplan, G.B.; Greenblatt, D.J.; Ehrenberg, B.L.; Goddard, J.E.; Cotreau, M.M.; Harmatz, J.S.; Shader, R.I. Dose-dependent pharmacokinetics and psychomotor effects of caffeine in humans. J. Clin. Pharmacol. 1997, 37, 693-703. [CrossRef] [PubMed]

156. Perera, V.; Grossa, A.S.; Xu, H.; McLachlan, A.J. Pharmacokinetics of caffeine in plasma and saliva, and the influence of caffeine abstinence on CYP1A2 metrics. J. Pharm. Pharmacol. 2011, 63, 1161-1168. [CrossRef]

157. Benowitz, N.L. Clinical pharmacology of caffeine. Annu. Rev. Med. 1990, 41, 277-288. [CrossRef] [PubMed]

158. Martínez-López, S.; Sarriá, B.; Gómez-Juaristi, M.; Goya, L.; Mateos, R.; Bravo-Clemente, L. Theobromine, caffeine, and theophylline metabolites in human plasma and urine after consumption of soluble cocoa products with different methylxanthine contents. Food Res. Int. 2014, 63, 446-455. [CrossRef]

159. Marks, V.; Kelly, J.F. Absorption of caffeine from tea, coffee, and coca cola. Lancet 1973, 1, 827. [CrossRef]

160. Biederbick, W.; Joseph, G.; Rump, A.; Theisohn, M.; Klaus, W. Caffeine in saliva after peroral intake: Early sample collection as a possible source of error. Ther. Drug Monit. 1997, 19, 521-524. [CrossRef] [PubMed]

161. Khanna, N.N.; Bada, H.S.; Somani, S.M. Use of salivary concentrations in the prediction of serum caffeine and theophylline concentrations in premature infants. J. Pediatr. 1980, 96, 494-499. [CrossRef]

162. Newton, R.; Broughton, L.J.; Lind, M.J.; Morrisson, P.J.; Rogers, H.J.; Bradbrook, I.D. Plasma and salivary pharmacokinetics of caffeine in man. Eur. J. Clin. Pharmacol. 1981, 21, 45-52. [CrossRef] [PubMed]

163. Soto, J.; Sacristan, A.; Alsar, M.J. Cerebrospinal fluid concentrations of caffeine following oral drug administration: Correlation with salivary and plasma concentrations. Ther. Drug Monit. 1994, 16, 108-110. [CrossRef] [PubMed]

164. Caraco, Y.; Zylber-Katz, E.; Berry, E.M.; Levy, M. Caffeine pharmacokinetics in obesity and following significant weight reduction. Int. J. Obes. Relat. Metab. Disord. 1995, 19, 234-239. [PubMed]

165. Abernethy, D.R.; Todd, E.L.; Schwartz, J.B. Caffeine disposition in obesity. Br. J. Clin. Pharmacol. 1985, 20, 61-66. [CrossRef]

166. Kamimori, G.H.; Somani, S.M.; Knowlton, R.G.; Perkins, R.M. The effects of obesity and exercise on the pharmacokinetics of caffeine in lean and obese volunteers. Eur. J. Clin. Pharmacol. 1987, 31, 595-600. [CrossRef]

167. Kimmel, C.A.; Kimmel, G.L.; White, C.G.; Grafton, T.F.; Young, J.F.; Nelson, C.J. Blood flow changes and conceptal development in pregnant rats in response to caffeine. Fundam. Appl. Toxicol. 1984, 4, $240-247$. [CrossRef]

168. Dorrbecker, S.H.; Kramer, P.A.; Dorrbecker, B.R.; Raye, J.R. Caffeine disposition in the pregnant rabbit. I. Pharmacokinetics following administration by intravenous bolus and continuous zero-order infusion. Dev. Pharmacol. Ther. 1988, 11, 109-117. [PubMed]

169. Djordjevic, N.; Ghotbi, R.; Bertilsson, L.; Jankovic, S.; Aklillu, E. Induction of CYP1A2 by heavy coffee consumption in Serbs and Swedes. Eur. J. Clin. Pharmacol. 2008, 64, 381-385. [CrossRef]

170. Gu, L.; Gonzalez, F.J.; Kalow, W.; Tang, B.K. Biotransformation of caffeine, paraxanthine, theobromine and theophylline by cDNA-expressed human CYP1A2 and CYP2E1. Pharmacogenetics 1992, 2, 73-77. [CrossRef] [PubMed]

171. Miners, O.; Birkett, D.J. The use of caffeine as a metabolic probe for human drug metabolizing enzymes. Gen. Pharmacol. 1996, 27, 245-249. [CrossRef]

172. Moura-Nunes, N.; Farah, A. Caffeine Consumption and Health; Romano, F.D., Russo, P.F., Eds.; Nova Science Publisher: New York, NY, USA, 2012; p. 1. 
173. Grant, D.M.; Campbell, M.E.; Tang, B.K.; Kalow, W. Biotransformation of caffeine by microsomes from human liver. Kinetics and inhibition studies. Biochem. Pharmacol. 1987, 36, 1251-1260. [CrossRef]

174. Jodynis-Liebert, J.; Matuszewska, A. Effect of toluidines and dinitrotoluenes on caffeine metabolic ratio in rat. Toxicol. Lett. 1999, 104, 159-165. [CrossRef]

175. Hakooz, N.M. Caffeine metabolic ratios for the in vivo evaluation of CYP1A2, N-acetyltransferase 2, xanthine oxidase and CYP2A6 enzymatic activities. Curr. Drug. Metab. 2009, 10, 329-338. [CrossRef] [PubMed]

176. Bozikas, V.P.; Papakosta, M.; Niopas, I.; Karavatos, A.; Mirtsou-Fidani, V. Smoking impact on CYP1A2 activity in a group of patients with schizophrenia. Eur. Neuropsychopharmacol. 2004, 14, 39-44. [CrossRef]

177. Ghotbi, R.; Christensen, M.; Roh, H.-K.; Ingelman-Sundberg, M.; Aklillu, E.; Bertilsson, L. Comparisons of CYP1A2 genetic polymorphisms, enzyme activity and the genotype-phenotype relationship in Swedes and Koreans. Eur. J. Clin. Pharmacol. 2007, 63, 537-546. [CrossRef]

178. Aranda, J.V.; Louridas, A.T.; Vitullo, B.B.; Thom, P.; Aldridge, A.; Haber, R. Metabolism of theophylline to caffeine in human fetal liver. Science 1979, 206, 1319-1321. [CrossRef] [PubMed]

179. Parsons, W.D.; Neims, A.H. Prolonged half-life of caffeine in healthy newborn infants. J. Pediatr. 1981, 98, 640-641. [CrossRef]

180. Stravic, B.; Gilbert, S.G. Caffeine metabolism: a problem in extrapolating results from animal studies to humans. Acta Pharma Iugosl. 1990, 40, 475-489.

181. Murphy, T.L.; McIvor, C.; Yap, A.; Cooksley, W.G.; Halliday, J.W.; Powell, L.W. The effect of smoking on caffeine elimination: Implications for its use as a semiquantitative test of liver function. Clin. Exp. Pharmacol. Physiol. 1988, 15, 9-13. [CrossRef] [PubMed]

182. Kalow, W.; Tang, B.K. Caffeine as a metabolic probe: Exploration of the enzyme-inducing effect of cigarette smoking. Clin. Pharmacol. Ther. 1991, 49, 44-48. [CrossRef]

183. Patwardhan, R.; Desmond, P.; Johnson, R.; Schenker, S. Impaired elimination of caffeine by oral contraceptive steroids. J. Lab. Clin. Med. 1980, 95, 603-608.

184. Brazier, J.L.; Ritter, J.; Berland, M.; Khenfer, D.; Faucon, G. Pharmacokinetics of caffeine during and after pregnancy. Dev. Pharmacol. Ther. 1983, 6, 315-322. [CrossRef]

185. Lamba, J.K.; Lin, Y.S.; Schuetz, E.G.; Thummel, K.E. Genetic contribution to variable human CYP3A-mediated metabolism. Adv. Drug Deliv. Rev. 2002, 54, 1271-1294. [CrossRef]

186. Rasmussen, B.B.; Brix, T.H.; Kyvik, K.O.; Brøsen, K. The interindividual differences in the 3-demthylation of caffeine alias CYP1A2 is determined by both genetic and environmental factors. Pharmacogenetics 2002, 12, 473-478. [CrossRef]

187. Guengerich, F.P. Cytochrome Pwhat have we learned and what are the future issues? Drug Metab. Rev. 2004, 36, 159-197. [CrossRef]

188. Landi, M.T.; Sinha, R.; Lang, N.P.; Kadlubar, F.F. Human cytochrome P4501A2. IARC Sci. Publ. 1999, 148, 173-195.

189. Chung, W.G.; Kang, J.H.; Park, C.S.; Cho, M.H.; Cha, Y.N. Effect of age and smoking on in vivo CYP1A2, flavin-containing monooxygenase, and xanthine oxidase activities in Koreans: Determination by caffeine metabolism. Clin. Pharmacol. Ther. 2000, 67, 258-266. [CrossRef] [PubMed]

190. Begas, E.; Kouvaras, E.; Tsakalof, A.; Papakosta, S.; Asprodini, E.K. In vivo evaluation of CYP1A2, CYP2A6, NAT-2 and xanthine oxidase activities in a Greek population sample by the RP-HPLC monitoring of caffeine metabolic ratios. Biomed. Chromatogr. 2007, 21, 190-200. [CrossRef] [PubMed]

191. Relling, M.V.; Lin, J.S.; Avers, G.D.; Evans, W.E. Racial and gender differences in N-acetyltransferase, xanthine oxidase, and CYP1A2 activities. Clin. Pharmacol. Ther. 1992, 52, 643-658. [CrossRef] [PubMed]

192. Sachse, C.; Brockmoller, J.; Bauer, S.; Roots, I. Functional significance of a C->A polymorphism in intron 1 of the cytochrome P450 CYP1A2 gene tested with caffeine. Br. J. Clin. Pharmacol. 1999, 47, 445-449. [CrossRef] [PubMed]

193. Ueng, Y.F.; Jan, W.C.; Lin, L.C.; Chen, T.L.; Guengerich, F.P.; Chen, C.F. The alkaloid rutaecarpine is a selective inhibitor of cytochrome P450 1A in mouse and human liver microsomes. Drug Metab. Dispos. 2002, 30, 349-353. [CrossRef] [PubMed]

194. Chen, Y.; Tu, J.H.; He, Y.J.; Zhang, W.; Wang, G.; Tan, Z.R.; Zhou, G.; Fan, L.; Zhou, H.H. Effect of sodium tanshinone II A sulfonate on the activity of CYP1A2 in healthy volunteers. Xenobiotica 2009, 39, 508-513. [CrossRef] 
195. Wang, X.; Lee, W.Y.; Or, P.M.; Yeung, J.H. Effects of major tanshinones isolated from Danshen (Salvia miltiorrhiza) on rat CYP1A2 expression and metabolism of model CYP1A2 probe substrates. Phytomedicine 2009, 16, 712-725. [CrossRef]

196. Wang, X.; Cheung, C.M.; Lee, M.Y.; Or, P.M.; Yeung, J.H. Major tanshinones of Danshen (Salvia miltiorrhiza) exhibit different modes of inhibition on human CYP1A2, CYP2C9, CYP2E1 and CYP3A4 activities in vitro. Phytomedicine 2010, 17, 868-875. [CrossRef]

197. Scott, N.R.; Chakraborty, J.; Marks, V. Urinary metabolites of caffeine in pregnant women. Br. J. Clin. Pharmacol. 1986, 22, 475-478. [CrossRef]

198. Bologa, M.; Tang, B.; Klein, J.; Tesoro, A.; Koren, G. Pregnancy-induced changes in drug metabolism in epileptic women. J. Pharmacol. Exp. Ther. 1991, 257, 735-740. [PubMed]

199. Cornelis, M.C.; El-Sohemy, A.; Kabagambe, E.K.; Campos, H. Coffee, CYP1A2 genotype, and risk of myocardial infarction. JAMA 2006, 295, 1135-1141. [CrossRef] [PubMed]

200. Djordjevic, N.; Carrillo, J.A.; Gervasini, G.; Jankovic, S.; Aklillu, E. In vivo evaluation of CYP2A6 and xanthine oxidase enzyme activities in the Serbian population. Eur. J. Clin. Pharmacol. 2010, 66, 571-578. [CrossRef] [PubMed]

201. Palatini, P.; Ceolotto, G.; Ragazzo, F.; Dorigatti, F.; Saladini, F.; Papparella, I.; Mos, L.; Zanata, G.; Santonastaso, M. CYP1A2 genotype modifies the association between coffee intake and the risk of hypertension. J. Hypertens. 2009, 27, 1594-1601. [CrossRef] [PubMed]

202. Rodenburg, E.M.; Eijgelsheim, M.; Geleijnse, J.M.; Amin, N.; van Duijn, C.M.; Hofman, A.; Uitterlinden, A.G.; Stricker, B.H.; Visser, L.E. CYP1A2 and coffee intake and the modifying effect of sex, age, and smoking. Am. J. Clin. Nutr. 2012, 96, 182-187. [CrossRef]

203. Cornelis, M.C.; Monda, K.L.; Yu, K.; Paynter, N.; Azzato, E.M.; Bennett, S.N.; Berndt, S.I.; Boerwinkle, E.; Chanock, S.; Chatterjee, N. Genome-wide meta-analysis identifies regions on 7p21 (AHR) and 15q24 (CYP1A2) as determinants of habitual caffeine consumption. PLoS Genet. 2011, 7, e1002033. [CrossRef] [PubMed]

204. Tantcheva-Poór, I.; Zaigler, M.; Rietbrock, S.; Fuhr, U. Estimation of cytochrome P-450 CYP1A2 activity in 863 healthy Caucasians using a saliva-based caffeine test. Pharmacogenetics 1999, 9, 131-144.

205. Carrillo, J.A.; Benitez, J. CYP1A2 activity, gender and smoking, as variables influencing the toxicity of caffeine. Br. J. Clin. Pharmacol. 1996, 41, 605-608. [CrossRef]

206. Denden, S.; Bouden, B.; Haj Khelil, A.; Ben Chibani, J.; Hamdaoui, M.H. Gender and ethnicity modify the association between the CYP1A2 rs762551 polymorphism and habitual coffee intake: Evidence from a meta-analysis. Genet. Mol. Res. 2016, 15. [CrossRef]

207. Arnaud, M.J. Identification, kinetic and quantitative study of [2-14C] and [1-Me-14C] caffeine metabolites in rat's urine by chromatographic separations. Biochem. Med. 1976, 16, 67-76. [CrossRef]

208. Tang-Liu, D.D.S.; Williams, R.L.; Reigelman, S. Disposition of caffeine and its metabolites in man. J. Pharmacol. Exp. Ther. 1983, 224, 180-185. [PubMed]

209. Callahan, H.M.; Robertson, R.S.; Arnaud, M.J.; Branfman, A.R.; McComish, M.F.; Yesair, D.H. Human metabolism of [1-methyl-14C]-and [2-14C] caffeine after oral administration. Drug Metab. Dispos. 1982, 10, 417-423. [PubMed]

210. Freedman, N.; Park, Y.; Abnet, C.C.; Hollenbeck, A.R.; Sinha, R. Association of coffee drinking with total and cause-specific mortality. N. Engl. J. Med. 2012, 366, 1891-1894. [CrossRef] [PubMed]

211. O'Keefe, J.H.; Bhatti, S.K.; Patil, H.R.; DiNicolantonio, J.J.; Lucan, S.C.; Lavie, C.J. Effects of habitual coffee consumption on cardiometabolic disease, cardiovascular health, and all-cause mortality. J. Am. Coll. Cardiol. 2013, 62, 1043-1051. [CrossRef] [PubMed]

212. Liu, J.; Sui, X.; Lavie, C.J.; Hebert, J.R.; Earnest, C.P.; Zhang, J.; Blair, S.N. Association of coffee consumption with all-cause and cardiovascular disease mortality. Mayo Clin. Proc. 2013, 88, 1066-1074. [CrossRef] [PubMed]

213. Crippa, A.; Discacciati, A.; Larsson, S.C.; Wolk, A.; Orsini, N. Coffee consumption and mortality from all causes, cardiovascular disease, and cancer: A dose-response meta-analysis. Am. J. Epidemiol. 2014, 180, 763-765. [CrossRef]

214. Loftfield, E.; Freedman, N.D.; Graubard, B.I.; Guertin, K.A.; Black, A.; Huang, W.-Y.; Shebl, F.M.; Mayne, S.T.; Sinha, R. Association of coffee consumption with overall and cause-specific mortality in a large US prospective cohort study. Am. J. Epidemiol. 2015, 182, 1010-1022. [CrossRef] 
215. Ding, M.; Satija, A.; Bhupathiraju, S.N.; Hu, Y.; Sun, Q.; Han, J.; Lopez-Garcia, E.; Willet, W.; van Dam, R.M.; $\mathrm{Hu}$, F.A. Association of coffee consumption with total and cause-specific mortality in 3 large prospective cohorts. Circulation 2015, 132, 2305-2315. [CrossRef] [PubMed]

216. Grosso, G.; Micek, A.; Godos, J.; Sciacca, S.; Pajak, A.; Martínez-González, M.A.; Giovannucci, E.L.; Galvano, F. Coffee consumption and risk of all-cause, cardiovascular, and cancer mortality in smokers and non-smokers: A dose-response meta-analysis. Eur. J. Epidemiol. 2016, 31, 1191-1205. [CrossRef]

217. Park, S.Y.; Freedman, N.D.; Haiman, C.A.; Marchand, L.L.; Wilkens, L.R.; Setiawan, V.W. Association of coffee consumption with total and cause-specific mortality among nonwhite populations. Ann. Intern. Med. 2017, 167, 228-235. [CrossRef]

218. Poole, R.; Kennedy, O.J.; Roderick, P.; Fallowfield, J.A.; Hayes, P.C.; Parkes, J. Coffee consumption and health: Umbrella review of meta-analyses of multiple health outcomes. BMJ 2017, 359, j5024. [CrossRef] [PubMed]

219. Grosso, G.; Godos, J.; Galvano, F.; Giovannucci, E.L. Coffee, caffeine, and health outcomes: An umbrella review. Annu. Rev. Nutr. 2017, 37, 131-156. [CrossRef] [PubMed]

220. McPherson, P.S.; Kim, Y.K.; Valdivia, H.; Knudson, C.M.; Takekura, H.; Franzini-Armstrong, C.; Coronado, R.; Campbell, K.P. The brain ryanodine receptor: A caffeine-sensitive calcium release channel. Neuron 1991, 7, 17-25. [CrossRef]

221. McLellan, T.M.; Caldwell, J.A.; Lieberman, H.R. A review of caffeine's effects on cognitive, physical and occupational performance. Neurosci. Biobehav. Rev. 2016, 71, 294-312. [CrossRef] [PubMed]

222. Gliottoni, R.C.; Meyers, J.R.; Arrigrimsson, S.A.; Boglio, S.P.; Motl, R.W. Effect of caffeine on quadriceps muscle pain during acute cycling exercise in low versus high caffeine consumers. Int. J. Sports Nutr. Exerc. Metab. 2009, 19, 150-161. [CrossRef]

223. Watson, J. Encyclopedia of Food Sciences and Nutrition; Caballero, B., Finglas, P.M., Toldra, F., Eds.; Academic Press: Cambridge, UK, 2003; p. 745.

224. Fredholm, B.B. Are methylxanthine effects due to antagonism of endogenous adenosine? Trends Pharmacol. Sci. 1980, 1, 129-132. [CrossRef]

225. Fredholm, B.B.; Svenningsson, P. Adenosine-dopamine interactions: Development of a concept and some comments on therapeutic possibilities. Neurology 2003, 61, 5-9. [CrossRef]

226. Nehlig, A.; Daval, J.L.; Debry, G. Caffeine and the central nervous system: Mechanisms of action, biochemical, metabolic and psychostimulant effects. Brain Res. Rev. 1992, 17, 139-170. [CrossRef]

227. Olson, C.A.; Thornton, J.A.; Adam, G.E.; Lieberman, H.R. Effects of 2 adenosine antagonists, quercetin and caffeine, on vigilance and mood. J. Clin. Psychopharmacol. 2010, 30, 573-578. [CrossRef]

228. Fisone, G.; Borgvist, A.; Usiello, A. Caffeine as a psychomotor stimulant: Mechanism of action. Cell. Mol. Life Sci. 2004, 61, 857-872. [CrossRef]

229. Einöther, S.J.L.; Giesbrecht, T. Caffeine as an attention enhancer: Reviewing existing assumptions. Psychopharmaco 2013, 225, 251-274. [CrossRef] [PubMed]

230. Nehlig, A. Is caffeine a cognitive enhancer? J. Alzheimers Dis. 2010, 20, 85-94. [CrossRef] [PubMed]

231. Nehlig, A. Effects of coffee/caffeine on brain health and disease: What should I tell my patients? Pract. Neurol. 2016, 16, 89-95. [CrossRef] [PubMed]

232. Nawrot, P.; Jordan, S.; Eastwood, J.; Rotstein, J.; Hugenholtz, A.; Feeley, M. Effects of caffeine on human health. Food Addit. Contam. 2003, 20,1-30. [CrossRef] [PubMed]

233. Goldstein, E.R.; Ziegenfuss, T.; Kalman, D.; Kreider, R.; Campbell, B.; Wilborn, C.; Taylor, L.; Willoughby, D.; Stout, J.; Graves, B.S.; et al. International society of sports nutrition position stand: Caffeine and performance. J. Int. Soc. Sports Nutr. 2010, 7, 5. [CrossRef] [PubMed]

234. Sinclair, C.J.; Geiger, J.D. Caffeine use in sports. A pharmacological review. J. Sports. Med. Phys. Fitness 2000, 40, 71-79. [PubMed]

235. Van Soeren, M.H.; Sathasivam, P.; Spriet, L.L.; Graham, T.E. Caffeine metabolism and epinephrine responses during exercise in users and nonusers. J. Appl. Physiol. 1985, 75, 805-812. [CrossRef]

236. European Food Safety Authority-(EFSA Panel on Dietetic Products, Nutrition and Allergies). Scientific Opinion on the Substantiation of Health Claims Related to Caffeine and Increase in Physical Performance during Short-Term High-Intensity Exercise, Increase in Endurance Performance, Increase in Endurance Capacity and Reduction in the Rated Perceived Exertion/Effort during Exercise; European Food Safety Authority: Parma, Italy, 2011.

237. Folmer, B.; Farah, A.; Jones, L.; Fogliano, V. Human Wellbeing-Sociability, Performance, and Health. In The Craft and Science of Coffee; Folmer, B., Ed.; Elsevier: Amsterdam, The Netherlands, 2017; pp. 493-520. 
238. Hogervost, E.; Bandelow, S.; Schmitt, J.; Jentjens, R.; Oliveira, M.; Allgrove, J.; Carter, T.; Gleeson, M. Caffeine improves physical and cognitive performance during exhaustive exercise. Med. Sci. Sports Exerc. 2008, 40, 1841-1851. [CrossRef]

239. Ballard, R.A.; Truog, W.E.; Cnaan, A.; Martin, R.J.; Ballard, P.L.; Merrill, J.D. Inhaled nitric oxide in preterm infants undergoing mechanical ventilation. N. Engl. J. Med. 2006, 355, 343-353. [CrossRef]

240. Dallas, C.; Gerbi, A.; Tenca, G.; Juchaux, F.; Bernard, F.X. Lipolytic effect of a polyphenolic citrus dry extract of red orange, grapefruit, orange (SINETROL) in human body fat adipocytes. Mechanism of action by inhibition of cAMP-phosphodiesterase (PDE). Phytomedicine 2008, 15, 783-792. [CrossRef]

241. Catlin, D.H.; Kammerer, R.C.; Hatton, C.K.; Severa, M.H.; Merdink, J.L. Analytical chemistry at the Games of the XXIIIrd Olympiad in Los Angeles, 1984. Clin. Chem. 1984, 33, 319-327.

242. World Anti-Doping Agency-WADA. Available online: http://www.wada-ama.org (accessed on 1 February 2019).

243. World Anti-Doping Agency (WADA). The 2009 Monitoring Program. Available online: www.wada-ama.org (accessed on 1 February 2019).

244. Monteiro, J.P.; Alves, G.M.; Oliveira, P.F.; Silva, B.M. Structure-bioactivity relationships of methylxanthines: Trying to make sense of all the promises and the drawbacks. Molecules 2016, 21, 974. [CrossRef] [PubMed]

245. Cappelletti, S.; Daria, P.; Sani, G.; Aromatario, M. Caffeine: Cognitive and physical performance enhancer or psychoactive drug? Curr. Neuropharmacol. 2015, 13, 71-88. [CrossRef] [PubMed]

246. Costa, M.S.; Botton, P.H.; Mioranzza, S.; Souza, D.O.; Porciúncula, L.O. Caffeine prevents age-associated recognition memory decline and changes brain-derived neurotrophic factor and tyrosine kinase receptor (TrkB) content in mice. Neuroscience 2008, 153, 1071-1078. [CrossRef] [PubMed]

247. Costenla, A.R.; Cunha, R.; de Mendonça, A. Caffeine, adenosine receptors, and synaptic plasticity. J. Alzheimers. 2010, 20, 25-34. [CrossRef]

248. Stefanello, N.; Spanevello, R.M.; Passamontic, S.; Porciúncula, L.; Bonane, C.D.; Olabiyif, A.A.; Rocha, J.B.; Assmanna, C.E.; Morscha, V.M.; Schetingera, M.R.C. Coffee, caffeine, chlorogenic acid, and the purinergic system. Food Chem. Toxicol. 2019, 123, 298-313. [CrossRef] [PubMed]

249. Shi, X.; Dalal, N.S.; Jain, A.C. Antioxidant behaviour of caffeine: Efficient scavenging of hydroxyl radicals. Food Chem. Toxicol. 1991, 29, 1-6. [CrossRef]

250. Varma, S.D.; Hegde, K.R.; Kovtun, S. Oxidative stress in lens in vivo: Inhibitory effect of caffeine. A preliminary report. Mol. Vis. 2010, 23, 501-505.

251. Lee, C. Antioxidant ability of caffeine and its metabolites based on the study of oxygen radical absorbing capacity and inhibition of LDL peroxidation. Clin. Chim. Acta 2000, 295, 141-154. [CrossRef]

252. Devasagayam, P.; Kesavan, P.C. Radioprotective and antioxidant action of caffeine: Mechanistic considerations. Indian J. Exp. Biol. 1996, 34, 291-297.

253. Gomez-Ruiz, J.A.; Leake, D.S.; Ames, J.M. In vitro antioxidant activity of coffee compounds and their metabolites. J. Agric. Food Chem. 2007, 55, 6962-6969. [CrossRef] [PubMed]

254. Moura-Nunes, N.; Perrone, D.; Farah, A.; Donangelo, C.M. The increase in human plasma antioxidant capacity after acute coffee intake is not associated with endogenous non-enzymatic antioxidant components. Int. Food Sci. Nutr. 2009, 60, 173-181. [CrossRef] [PubMed]

255. Buscemi, S.; Batsis, J.A.; Arcoleo, G.; Verga, S. Coffee and endothelial function: A battle between caffeine and antioxidants? Eur. J. Clin. Nutr. 2010, 64, 1242-1243. [CrossRef] [PubMed]

256. Vicente, S.J.V.; Queiroz, Y.S.; Gotlieb, S.L.D.; Torres, A.F.S. Stability of phenolic compounds and antioxidant capacity of regular and decaffeinated coffees. Braz. Arch. Biol. Technol. 2014, 57, 110. [CrossRef]

257. Frost-Meyer, N.J.; Logomarsino, J.V. Impact of coffee components on inflammatory markers: A review. J. Func. Foods 2012, 4, 819-830. [CrossRef]

258. Lee, I.A.; Kamba, A.; Low, D.; Mizoguchi, E. Novel methylxanthine derivative-mediated anti-inflammatory effects in inflammatory bowel disease. World J. Gastroenterol. 2014, 20, 1127-1138. [CrossRef] [PubMed]

259. Daly, J.W. Caffeine analogs: Biomedical impact. Cell. Mol. Life Sci. 2007, 64, 2153-2169. [CrossRef] [PubMed]

260. Tauler, P.; Martinez, S.; Martinez, P.; Lozano, L. Effects of caffeine supplementation on plasma and blood mononuclear cell interleukin-10 levels after exercise. Hum. Kinet. J. 2015, 26, 8-16. [CrossRef]

261. Ouyang, W.; Rutz, S.; Crellin, N.K.; Valdez, P.A.; Hymowitz, S.G. Regulation and functions of the IL-10 family of cytokines in inflammation and disease. Annu. Rev. Immunol. 2010, 29, 71-109. [CrossRef] 
262. Rittera, M.; Hohenberger, K.; Altera, P.; Herzuma, M.; Tebbe, J.; Maisch, M. Caffeine inhibits cytokine expression in lymphocytes. Cytokine 2005, 30, 177-181. [CrossRef]

263. Horrigan, L.A.; Kelly, J.P.; Connor, T.J. Caffeine suppresses TNF- $\alpha$ production via activation of the cyclic $\mathrm{AMP} /$ protein kinase A pathway. Int. Immunopharmacol. 2004, 4, 1409-1417. [CrossRef] [PubMed]

264. Antonio, A.G.; Iorio, N.L.P.; Pierro, V.S.S.; Candreva, M.S.; Farah, A.; dos Santos, K.R.N.; Maia, L.C. Inhibitory properties of Coffea canephora extract against oral bacteria and its effect on demineralisation of deciduous teeth. Arch. Oral Biol. 2011, 56, 556-564. [CrossRef] [PubMed]

265. Van Loreven, C.; Broukal, Z.; Oganessian, E. Functional foods/ingredients and dental caries. Eur. J. Nutr. 2012, 51, 15-25. [CrossRef] [PubMed]

266. Sharma, R.; Reddy, V.K.L.; Prashant, G.M.; Ojha, V.; Kumar, N.P.G. Antimicrobial and anti-adherence activity of various combinations of coffee-chicory solutions on Streptococcus mutans: An in-vitro study. J. Oral. Maxillofac. Pathol. 2014, 18, 201-206. [CrossRef] [PubMed]

267. Ibrahim, S.A.; Salameh, M.M.; Phetsomphou, H.; Yang, H.; Seo, C.W. Application of caffeine, 1,3,7-trimethylxanthine, to control Escherichia coli O157:H7. Food Chem. 2006, 99, 645-650. [CrossRef]

268. Maia, L.; de Mendonça, A. Does caffeine intake protect from Alzheimer's disease? Eur. J. Neurol. 2002, 9, 377-382. [CrossRef] [PubMed]

269. Eskelinen, M.H.; Ngandu, T.; Tuomilehto, J.; Soininena, H.; Kivipelto, M.J. Midlife coffee and tea drinking and the risk of late-life dementia: A population-based CAIDE study. J. Alzheimers Dis. 2009, 16, 85-91. [CrossRef] [PubMed]

270. Arendash, G.W.; Cao, C. Caffeine and coffee as therapeutics against Alzheimer's disease. J. Alzheimers Dis. 2010, 20, 117-126. [CrossRef]

271. Costa, J.; Lunet, N.; Santos, C.; Santos, J.; Vaz-Cameiro, A. Caffeine exposure and the risk of Parkinson's disease: A systemic review and meta-analysis of observational studies. J. Alzheimers Dis. 2010, 20, 221-238. [CrossRef] [PubMed]

272. Postuma, R.B.; Lang, A.E.; Munhoz, R.P.; Charland, K.; Pelletier, A.; Moscovich, M.; Filla, L.; Zanatta, D.; Rios Romenets, S.; Altman, R. Caffeine for treatment of Parkinson disease: A randomized controlled trial. Neurology 2012, 79, 651-658. [CrossRef] [PubMed]

273. Hashimoto, M.; Rockenstein, E.; Crews, L.; Masliah, E. Role of protein aggregation in mitochondrial dysfunction and neurodegeneration in Alzheimer's and Parkinson's diseases. Neuromol. Med. 2003, 4, 21-36. [CrossRef]

274. Eskelinen, M.H.; Kivipelto, M. Caffeine as a protective factor in dementia and Alzheimer's disease. J. Alzheimers. Dis. 2010, 20, 167-174. [CrossRef] [PubMed]

275. Hardy, J.; Gwinn-Hardy, K. Genetic classification of primary neurodegenerative disease. Science 1998, 282, 1075-1079. [CrossRef] [PubMed]

276. Dauer, W.; Przedborski, S. Parkinson's disease: Mechanisms and models. Neuron 2003, 39, 889-909. [CrossRef]

277. Chen, J.-F. Caffeine and Parkinson's disease: From molecular targets to epidemiology to clinic trials. In Coffee: Consumption and Health Implications; Farah, A., Ed.; Royal Society of Chemistry: London, UK, 2019; ISBN 978-1782620044.

278. Ascherio, A.; Zhang, S.M.; Hernan, M.A.; Kawachi, I.; Colditz, G.A.; Speizer, F.E.; Willett, W.C. Prospective study of caffeine consumption and risk of Parkinson's disease in men and women. Ann. Neurol. 2001, 50, 56-63. [CrossRef] [PubMed]

279. Ascherio, A.; Weisskopf, M.G.; O’Reilly, E.J.; McCullough, M.L.; Calle, E.E.; Rodriguez, C.; Thun, M.J. Coffee consumption, gender, and Parkinson's disease mortality in the cancer prevention study II cohort: The modifying effects of estrogen. Am. J. Epidemiol. 2004, 160, 977-984. [CrossRef] [PubMed]

280. Ascherio, A.; Chen, H.; Schwarzschild, M.A.; Zhang, S.M.; Colditz, G.A.; Speizer, F.E. Caffeine, postmenopausal estrogen, and risk of Parkinson's disease. Neurology 2003, 60, 790-795. [CrossRef] [PubMed]

281. Blum, D.; Farah, A.; Lopes, L.V. Coffee and Alzheimer's Disease. In Coffee: Consumption and Health Implications; Farah, A., Ed.; Royal Society of Chemistry: London, UK, 2019; ISBN 978-1782620044.

282. Checler, F. Processing of the beta-amyloid precursor protein and its regulation in Alzheimer's disease. J. Neurochem. 1995, 65, 1431-1444. [CrossRef] [PubMed] 
283. Ittner, L.M.; Ke, Y.D.; Delerue, F.; Bi, N.; Gladbach, A.; van Eersel, J.; Wolfing, H.; Chieng, B.C.; Christie, M.J.; Napier, I.A. Dendritic function of tau mediates amyloid-beta toxicity in Alzheimer's disease mouse models. Cell 2010, 142, 387-397. [CrossRef]

284. Arendash, G.W.; Schleif, W.; Rezai Zadeh, K.; Jackson, E.K.; Zacharia, L.C.; Cracchiolo, J.R.; Shippy, D.; Tan, J. Caffeine protects Alzheimer's mice against cognitive impairment and reduces brain $\beta$-amyloid production. Neuroscience 2006, 142, 941-952. [CrossRef]

285. Waite, M. Treatment for Alzheimer's disease: Has anything changed? Aust. Prescr. 2015, 38, 60-63. [CrossRef] [PubMed]

286. Liu, Q.P.; Wu, Y.F.; Cheng, H.Y.; Xia, T.; Ding, H.; Wang, H.; Wang, Z.M.; Xu, Y. Habitual coffee consumption and risk of cognitive decline/dementia: A systematic review and meta-analysis of prospective cohort studies. Nutrition 2016, 32, 628-636. [CrossRef] [PubMed]

287. Arendash, G.W.; Mori, T.; Cao, C.; Mamcarz, M.; Runfeldt, M.; Dickson, A.; Rezai-Zadeh, K.; Tane, J.; Citron, B.A.; Lin, X.; et al. Caffeine reverses cognitive impairment and decreases brain amyloid-beta levels in aged Alzheimer's disease mice. J. Alzheimers Dis. 2009, 17, 661-680. [CrossRef] [PubMed]

288. Gelber, R.P.; Petrovitch, H.; Masaki, K.H.; Ross, G.W.; White, L.R. Coffee intake in midlife and risk of dementia and its neuropathologic correlates. J. Alzheimer's Dis. 2011, 23, 607-615. [CrossRef] [PubMed]

289. Ruhl, C.E.; Everhart, J.E. Coffee and tea consumption are associated with a lower incidence of chronic liver disease in the United States. Gastroenterology 2005, 129, 1928-1936. [CrossRef] [PubMed]

290. Casiglia, E.; Spolaore, P.; Inocchio, G. Unexpected effects of coffee consumption on liver enzymes. Eur. J. Epidemiol. 1993, 9, 293-297. [CrossRef]

291. Jaruvongvanich, V.; Sanguankeo, A.; Klomjit, N.; Upala, S. Effects of caffeine consumption in patients with chronic hepatitis C: A systematic review and meta-analysis. Clin. Res. Hepatol. Gastroenterol. 2017, 41, 46-55. [CrossRef] [PubMed]

292. Shen, H.; Rodriguez, A.C.; Shiani, A.; Lipka, S.; Shahzad, G.; Kumar, A.; Mustacchia, P. Association between caffeine consumption and nonalcoholic fatty liver disease: A systemic review and meta-analysis. Ther. Adv. Gastroenterol. 2016, 9, 113-120. [CrossRef]

293. Machado, S.R.; Parise, E.R.; Carvalho, L. Coffee has hepatoprotective benefits in Brazilian patients with chronic hepatitis $\mathrm{C}$ even in lower daily consumption than in American and European populations. Braz. J. Infect. Dis. 2014, 18, 170-176. [CrossRef]

294. Loomis, D.; Guyton, K.Z.; Grosse, Y.; Lauby-Secretan, B.; El Ghissassi, F.; Bouvard, V.; Benbrahim-Tallaa, L.; Guha, N.; Mattock, H.; Straif, K. Carcinogenicity of drinking coffee, mate, and very hot beverages. Lancet Oncol. 2016, 17, 877-878. [CrossRef]

295. La Vecchia, C. Coffee, liver enzymes, cirrhosis and liver cancer. J. Hepatol. 2005, 42, 444-446. [CrossRef] [PubMed]

296. Klatsky, A.L.; Morton, C.; Udaltsova, N.; Friedman, G.D. Coffee, cirrhosis, and transaminase enzymes. Arch. Intern. Med. 2006, 166, 1190-1195. [CrossRef] [PubMed]

297. Larsson, S.C.; Wolk, A. Coffee consumption and risk of liver cancer: A meta-analysis. Gastroenterology 2007, 132, 1740-1745. [CrossRef] [PubMed]

298. Bravi, F.; Bosetti, C.; Tavani, A.; Bagnardi, V.; Gallus, S.; Negri, E. Coffee drinking and hepatocellular carcinoma risk: A meta-analysis. Hepatology 2007, 46, 430-435. [CrossRef] [PubMed]

299. Gressner, O.A.; Lahme, B.; Rehbein, K.; Siluschek, M.; Weiskirchen, R.; Gressner, A.M. Pharmacological application of caffeine inhibits TGF- $\beta$-stimulated connective tissue growth factor expression in hepatocytes via PPAR $\gamma$ and SMAD2/3-dependent pathways. J. Hepatol. 2008, 49, 758-767. [CrossRef] [PubMed]

300. Shim, S.G.; Jun, D.W.; Kim, E.K.; Saeed, W.K.; Lee, K.N.; Lee, H.L.; Lee, O.Y.; Choi, H.S.; Yoon, B.C. Caffeine attenuates liver fibrosis via defective adhesion of hepatic stellate cells in cirrhotic model. JGH 2013, 28, 1877-1884. [CrossRef]

301. Saaksjarvi, K.; Knekt, P.; Rissanen, H.; Laaksonen, M.A.; Reunanen, A.; Mannisto, S. Prospective study of coffee consumption and risk of Parkinson's disease. Eur. J. Clin. Nutr. 2008, 62, 908-915. [CrossRef] [PubMed]

302. Kyrozis, A.; Ghika, A.; Stathopoulos, P.; Vassilopoulos, D.; Trichopoulos, D.; Trichopoulou, A. Dietary and lifestyle variables in relation to incidence of Parkinson's disease in Greece. Eur. J. Epidemiol. 2013, 28, 67-77. [CrossRef] 
303. Kenborg, L.; Lassen, C.F.; Ritz, B.; Andersen, K.K.; Christensen, J.; Schernhammer, E.S.; Hansen, J.; Wermuth, L.; Rod, N.H.; Olsen, J.H. Lifestyle, family history, and risk of idiopathic Parkinson disease: A large Danish case-control study. Am. J. Epidemiol. 2015, 181, 808-816. [CrossRef]

304. Qi, H.; Li, S. Dose-response meta-analysis on coffee, tea and caffeine consumption with risk of Parkinson's disease. Geriatr. Gerontol. Int. 2014, 14, 430-439. [CrossRef]

305. Lindsay, J.; Laurin, D.; Verreault, R.; Hebert, R.; Helliwell, B.; Hill, G.B.; McDowell, I. Risk factors for Alzheimer's disease: A prospective analysis from the Canadian Study of Health and Aging. Am. J. Epidemiol. 2002, 156, 445-453. [CrossRef] [PubMed]

306. Panza, F.; Solfrizzi, V.; Barulli, M.R.; Bonfiglio, C.; Guerra, V.; Osella, A.; Seripa, D.; Sabbà, C.; Pilotto, A.; Logroscino, G. Coffee, tea, and caffeine consumption and prevention of late-life cognitive decline and dementia: A systematic review. J. Nutr. Health Aging 2015, 19, 313-328. [CrossRef] [PubMed]

307. Kenned, O.J.; Roderick, P.; Buchanan, R.; Fallowfield, J.A.; Hayes, P.C.; Parkes, J. Coffee, including caffeinated and decaffeinated coffee, and the risk of hepatocellular carcinoma: A systematic review and dose-response meta-analysis. BMJ Open 2017, 7, e013739. [CrossRef] [PubMed]

308. Wijarnpreecha, K.; Thongprayoon, C.; Ungprasert, P. Impact of caffeine in hepatitis C virus infection: A systematic review and meta-analysis. Eur. J. Gastroenterol. Hepatol. 2017, 29, 17-22. [CrossRef] [PubMed]

309. Ruhl, C.E.; Everhart, J.E. Coffee and caffeine consumption reduce the risk of elevated serum alanine aminotransferase activity in the United States. Gastroenterology 2005, 128, 24-32. [CrossRef] [PubMed]

310. Corrao, G.; Zambon, A.; Bagnardi, V.; D'Amicis, A.; Klatsky, A. Coffee, caffeine, and the risk of liver cirrhosis. Ann. Epidemiol. 2001, 11, 458-465. [CrossRef]

311. Food and Drug Administration-FDA. Select Committee on GRAS substances (SCOGS); FDA: Silver Spring, MD, USA, 1959.

312. Scientific Committee for Food-SCF. Report of the Scientific Committee for Food on Caffeine; SCF: Oslo, Norway, 1983.

313. Mulder, C.J. Chemische Untersuchung des chinesischen und des javanischen. Thees. Arch. Pharm. 1838, 65, 68. [CrossRef]

314. Lehmann, C.G. Lehrbuch der physiologischen Chemie. Leipizig 1850, 2, 367.

315. James, J.E. Caffeine and Health; James, J.E., Ed.; London Academic Press: London, UK, 1991; p. 63.

316. Lima, J.P.; Farah, A. Potential negative effects of caffeine consumption on health. In Coffee: Consumption and Health Implications; Farah, A., Ed.; Royal Society of Chemistry: London, UK, 2019; ISBN 978-1782620044.

317. Frerichs, F.T. Die Verdauung. Handbuch Phys. 1846, 3, 721.

318. Tarka, S.M.; Cornish, H.H. The toxicology of cocoa and methylxanthines: A review of the literature. Crit. Rev. Toxicol. 1982, 9, 275-312. [CrossRef]

319. Kerrigan, S.; Lindsey, T. Fatal caffeine overdose: Two case reports. Forensic. Sci. Int. 2005, 153, 67-69. [CrossRef] [PubMed]

320. Stavric, B.; Klassen, R.; Watkinson, B.; Karpinski, K.; Stapley, R.; Fried, P. Variability in caffeine consumption from coffee and tea: Possible significance for epidemiological studies. Food Chem. Toxicol. 1988, 26, 111-118. [CrossRef]

321. Arya, L.A.; Myers, D.L.; Jackson, N.D. Dietary caffeine intake and the risk for detrusor instability: A casecontrol study. Obstet. Gynecol. 2000, 96, 85-89. [CrossRef] [PubMed]

322. Tajima, Y. Coffee-induced hypokalaemia. Clin. Med. Insights Case Rep. 2010, 3, 9-13.

323. Food Standards Australia New Zealand. Report from the Expert Working Group on the Safety Aspects of Dietary Caffeine; Food Standards Australia New Zealand: Canberra, Australia, 2000.

324. Nordic Council of Ministers. Risk Assessment of Caffeine among Children and Adolescents in the Nordic Countries; Nordic Council of Ministers: Copenhagen, Denmark, 2008.

325. Belgium Superior Health Council. The Use of Caffeine in Foodstuffs; Belgium Superior Health Council: Bruxelles, Belgium, 2012.

326. Rogers, P.J.; Hohoff, C.; Heatherley, S.V.; Mullings, E.L.; Maxfield, P.J.; Evershed, R.P.; Deckert, J.; Nutt, D.J. Association of the anxiogenic and alerting effects of caffeine with ADORA2A and ADORA1 polymorphisms and habitual level of caffeine consumption. Neuropsychopharmacology 2010, 35, 1973-1983. [CrossRef] [PubMed] 
327. Childs, E.; Hohoff, C.; Deckert, J.; Xu, K.; Badner, J.; de Wit, H. Association between ADORA2A and DRD2 polymorphisms and caffeine-induced anxiety. Neuropsychopharmacology 2008, 33, 2791-2800. [CrossRef] [PubMed]

328. Ammon, H.P. Biochemical mechanism of caffeine tolerance. Arch. Pharm. 1991, 324, 261-267. [CrossRef]

329. Dorfman, L.J.; Jarvik, M.E. Comparative stimulant and diuretic actions of caffeine and theobromine in man. Clin. Pharmacol. Ther. 1970, 11, 869-872. [CrossRef]

330. Zwyghuizen-Doorenbos, A.; Roehrs, T.A.; Lipschutz, L.; Timms, V.; Roth, T. Effects of caffeine on alertness. Psychopharmacology 1990, 100, 36-39. [CrossRef]

331. Elkins, R.N.; Rapoport, J.L.; Zahn, T.P.; Buchsbaum, M.S.; Weingartner, H.; Kopin, I.J.; Langer, D.; Johnson, C. Acute effects of caffeine in normal prepubertal boys. Am. J. Psychiatry 1981, 138, 178-183. [CrossRef]

332. Temple, J.L.; Ziegler, A.M.; Graczyk, A.M.; Crandall, A. Effects of acute and chronic caffeine on risk-taking behavior in children and adolescents. J. Psychopharmacol. 2017, 31, 561-568. [CrossRef] [PubMed]

333. Rapoport, J.L.; Elkins, R.; Neims, A.; Zahn, T.; Berg, C.J. Behavioral and autonomic effects of caffeine in normal boys. Dev. Pharmacol. Ther. 1981, 3, 74-82. [CrossRef] [PubMed]

334. Rapoport, J.L.; Berg, C.J.; Ismond, D.R.; Zahn, T.P.; Neims, A. Behavioral effects of caffeine in children. Relationship between dietary choice and effects of caffeine challenge. Arch. Gen. Psychiatry 1984, 41, 1073-1079. [CrossRef] [PubMed]

335. Leviton, A. Behavioral correlates of caffeine consumption by children. Clin. Pediatr. 1992, 31, 742. [CrossRef] [PubMed]

336. Baer, R.A. Effects of caffeine on classroom behavior, sustained attention, and a memory task in preschool children. J. App. Behav. Anal. 1987, 20, 225-234. [CrossRef]

337. Bernstein, G.A.; Carroll, M.E.; Crosby, R.D.; Perwien, A.R.; Go, F.S.; Benowitz, N.L. Caffeine effects on learning, performance, and anxiety in normal school-age children. J. Am. Acad. Child Adolesc. Psychiatry 1994, 33, 407-415. [CrossRef] [PubMed]

338. Hale, K.L.; Hughes, J.R.; Oliveto, A.H.; Higgins, S.T. Caffeine self-administration and subjective effects in adolescents. Exp. Clin. Pharmacol. 1995, 3, 364-370. [CrossRef]

339. Davis, R.E.; Osorio, I. Childhood caffeine tic syndrome. Pediatrics 1998, 101, e4. [CrossRef]

340. Temple, J.L.; Bulkley, A.M.; Briatico, L.; Dewey, A.M. Sex differences in reinforcing value of caffeinated beverages in adolescents. Behav. Pharmacol. 2009, 20, 731-741. [CrossRef]

341. Temple, J.L.; Ziegler, A.M. Gender differences in subjective and physiological responses to caffeine and the role of steroid hormones. J. Caffeine Res. 2011, 1, 41-48. [CrossRef]

342. Stein, M.A.; Krasowski, M.; Leventhal, B.L.; Phillips, W.; Bender, B.G. Behavioral and cognitive effects of methylxanthines. A meta-analysis of theophylline and caffeine. Arch. Pediatr. Adolesc. Med. 1996, 150, 284-288. [CrossRef] [PubMed]

343. Robertson, D.; Frolich, J.C.; Carr, R.K.; Watson, J.T.; Hollifield, J.W.; Shand, D.G.; Oates, J.A. Effects of caffeine on plasma renin activity, catecholamines and blood pressure. N. Engl. J. Med. 1978, 298, 1811-1886. [CrossRef] [PubMed]

344. Dobmeyer, D.J.; Stine, R.A.; Leier, C.V.; Greenberg, R.; Schaal, S.F. The arrhythmogenic effects of caffeine in human beings. N. Engl. J. Med. 1983, 308, 814-816. [CrossRef] [PubMed]

345. Nurminen, M.L.; Niittynen, L.; Korpela, R.; Vapaatalo, H. Coffee, caffeine and blood pressure: A critical review. Eur. J. Clin. Nutr. 1999, 53, 831-839. [CrossRef] [PubMed]

346. Watanabe, T.; Arai, Y.; Mitsui, Y.; Kusaura, T.; Okawaand, W.; Kajihara, Y. The blood pressure-lowering effect and safety of chlorogenic acid from green coffee bean extract in essential hypertension. Clin. Exp. Hypertens. 2006, 28, 439-449. [CrossRef] [PubMed]

347. Suzuki, A.; Kagawa, D.; Fujii, A.; Ochiai, R.; Tokimitsu, I.; Saito, I. Short- and long-term effects of ferulic acid on blood pressure in spontaneously hypertensive rats. Am. J. Hypertens. 2002, 15, 351-357. [CrossRef]

348. Farag, N.H.; Whitsett, T.L.; McKey, B.S.; Wilson, M.F.; Vincent, A.S.; Everson-Rose, S.A.; Lovallo, W.R. Caffeine and blood pressure response: Sex, age, and hormonal status. J. Wom. Health 2010, 19, 1171-1176. [CrossRef] [PubMed]

349. Worthley, M.I.; Prabhu, A.; De Sciscio, P.; Schultz, C.; Sanders, P.; Willoughby, S.R. Detrimental effects of energy drink consumption on platelet and endothelial function. Am. J. Med. 2010, 123, 1841-1887. [CrossRef] [PubMed] 
350. Buscemi, S.; Mattina, A.; Tranchina, M.R.; Verga, S. Acute effects of coffee on QT interval in healthy subjects. Nutr. J. 2011, 10, 15. [CrossRef] [PubMed]

351. Shi, J.; Benowitz, N.L.; Denaro, C.P.; Sheiner, L.B. Pharmacokinetic-pharmacodynamic modeling of caffeine: Tolerance to pressor effects. Clin. Pharmacol. Ther. 1993, 53, 6-14. [CrossRef]

352. Green, P.J.; Kirby, R.; Suls, J. The effects of caffeine on blood pressure and heart rate: A review. Ann. Behav. Med. 1996, 18, 201-216. [CrossRef] [PubMed]

353. Greenland, S. A meta-analysis of coffee, myocardial infarction, and coronary death. Epidemiology 1993, 4, 366-374. [CrossRef] [PubMed]

354. Wikoff, D.; Welsh, B.T.; Henderson, R.; Brorby, G.P.; Britt, J.; Myers, E.; Goldberger, J.; Lieberman, H.R.; O'Brien, C.; Peck, J.; et al. Systematic review of the potential adverse effects of caffeine consumption in healthy adults, pregnant women, adolescents, and children. Food Chem. Toxicol. 2017, 109, 585-648. [CrossRef] [PubMed]

355. Ding, M.; Bhupathiraju, S.N.; Satija, A.; van Dam, R.M.; Hu, F.B. Long-term coffee consumption and risk of cardiovascular disease: A systematic review and a dose-response meta-analysis of prospective cohort studies. Circulation 2014, 129, 643-659. [CrossRef] [PubMed]

356. Caldeira, D.; Martins, C.; Alves, L.B.; Pereira, H.; Ferreira, J.J.; Costa, J. Caffeine does not increase the risk of atrial fibrillation: A systematic review and meta-analysis of observational studies. Heart 2013, 99, 1383-1389. [CrossRef] [PubMed]

357. Kim, B.; Nam, Y.; Kim, J.; Choi, H.; Won, C. Coffee consumption and stroke risk: A meta-analysis of epidemiologic studies. Korean J. Fam. Med. 2012, 33, 356-365. [CrossRef] [PubMed]

358. Salazar-Martinez, E.; Willett, W.C.; Ascherio, A.; Manson, J.E.; Leitzmann, M.F.; Stampfer, M.J.; Hu, F.B. Coffee consumption and risk for type 2 diabetes mellitus. Ann. Intern. Med. 2004, 140, 1-8. [CrossRef] [PubMed]

359. van Dam, R.M.; Willett, W.C.; Manson, J.E.; Hu, F.B. Coffee, caffeine, and risk of type 2 diabetes: A prospective cohort study in younger and middle-aged U.S. women. Diabetes Care 2006, 29, 398-403. [CrossRef]

360. Hjellvik, V.; Tverdal, A.; Strom, H. Boiled coffee intake and subsequent risk for type 2 diabetes. Epidemiology 2011, 22, 418-421. [CrossRef]

361. Floegel, A.; Pischon, T.; Bergmann, M.M.; Teucher, B.; Kaaks, R.; Boeing, H. Coffee consumption and risk of chronic disease in the European Prospective Investigation into Cancer and Nutrition (EPIC)-Germany study. Am. J. Clin. Nutr. 2012, 95, 901-908. [CrossRef]

362. Doo, T.; Morimoto, Y.; Steinbrecher, A.; Kolonel, L.N.; Maskarinec, G. Coffee intake and risk of type 2 diabetes: The multiethnic cohort. Public Health Nutr. 2014, 17, 1328-1336. [CrossRef] [PubMed]

363. Carlström, M.; Larsson, S.C. Coffee consumption and reduced risk of developing type 2 diabetes: A systematic review with meta-analysis. Nutr. Rev. 2018, 76, 395-417. [CrossRef] [PubMed]

364. Ding, M.; Bhupathiraju, S.N.; Chen, M.; van Dam, R.M.; Hu, F.B. Caffeinated and decaffeinated coffee consumption and risk of type 2 diabetes: A systematic review and a dose-response meta-analysis. Diabetes Care 2014, 37, 569-586. [CrossRef] [PubMed]

365. Shearer, J.; Sellars, E.; Farah, A.; Graham, T.E.; Wasserman, D.H. Effects of chronic coffee consumption on glucose kinetics in the conscious rat. Can. J. Physiol. Pharmacol. 2007, 85, 823-830. [CrossRef] [PubMed]

366. Lane, J.D.; Feinglos, M.N.; Surwit, R.S. Caffeine increases ambulatory glucose and postprandial response in coffee drinkers with type 2 diabetes. Diabetes Care 2008, 31, 221-222. [CrossRef] [PubMed]

367. Moisey, L.L.; Kacker, S.; Bickerton, A.C.; Robinson, L.E.; Graham, T.E. Caffeinated coffee consumption impairs blood glucose homeostasis in response to high and low glycemic index meals in healthy men. Am. J. Clin. Nutr. 2008, 87, 1254-1261. [CrossRef] [PubMed]

368. Robinson, L.E.; Spafford, C.; Graham, T.E.; Smith, G.N. Acute caffeine ingestion and glucose tolerance in women with or without gestational diabetes mellitus. J. Obstet. Gynaecol. Can. 2009, 31, 304-312. [CrossRef]

369. Lane, J.D. Caffeine, glucose metabolism, and type 2 diabetes. J. Caffeine Res. 2011, 1, 23-28. [CrossRef]

370. Han, D.H.; Hansen, P.A.; Nolte, L.A.; Holloszy, J.O. Removal of adenosine decreases the responsiveness of muscle glucose transport to insulin and contractions. Diabetes 1998, 47, 1671-1675. [CrossRef]

371. Keijzers, G.B.; De Galan, B.E.; Tack, C.J.; Smits, P. Caffeine can decrease insulin sensitivity in humans. Diabetes Care 2002, 25, 364-369. [CrossRef] 
372. Wu, T.; Willett, W.C.; Hankinson, S.E.; Giovannucci, E. Caffeinated coffee, decaffeinated coffee, and caffeine in relation to plasma C-peptide levels, a marker of insulin secretion, in U.S. women. Diabetes Care 2005, 28, 1390-1396. [CrossRef] [PubMed]

373. Greenberg, J.A.; Geliebter, A.; Boozer, C.N. Coffee, diabetes, and weight control. Am. J. Clin. Nutr. 2006, 84, 682-693. [CrossRef] [PubMed]

374. Pereira, M.A.; Parker, E.D.; Folsom, A.R. Coffee consumption and risk of type 2 diabetes mellitus: An 11-year prospective study of 28812 postmenopausal women. Arch. Intern. Med. 2006, 166, 1311-1316. [CrossRef] [PubMed]

375. Hamer, M.; Witte, D.R.; Mosdøl, A.; Marmot, M.G.; Brunner, E.J. Prospective study of coffee and tea consumption in relation to risk of type 2 diabetes mellitus among men and women: The Whitehall II study. Br. J. Nutr. 2008, 100, 1046-1053. [CrossRef] [PubMed]

376. Sartorelli, D.S.; Fagherazzi, G.; Balkau, B.; Touillaud, B.M.S.; Boutron-Ruault, M.C.; Lauzon-Guillain, B.; Clavel-Chapelon, F. Differential effects of coffee on the risk of type 2 diabetes according to meal consumption in a French cohort of women: The E3N/EPIC cohort study. Am. J. Clin. Nutr. 2010, 91, 1002-1012. [CrossRef]

377. Bhupathiraju, S.N.; Pan, A.; Malik, V.S.; Manson, J.E.; Willett, W.C.; van Dam, R.M.; Hu, F.B. Caffeinated and caffeine-free beverages and risk of type 2 diabetes. Am. J. Clin. Nutr. 2013, 97, 155-166. [CrossRef] [PubMed]

378. Battram, D.S.; Arthur, R.; Weekes, A.; Graham, T.E. The glucose intolerance induced by caffeinated coffee ingestion is less pronounced than that due to alkaloid caffeine in men. J. Nutr. 2006, 136, 1276-1280. [CrossRef] [PubMed]

379. Johnston, K.L.; Clifford, M.N.; Morgan, L.M. Coffee acutely modifies gastrointestinal hormone secretion and glucose tolerance in humans: Glycemic effects of chlorogenic acid and caffeine. Am. J. Clin. Nutr. 2003, 78, 728-733. [CrossRef] [PubMed]

380. Porto, A.C.V.; Farah, A. Potential effects of trigonelline derivatives on health. In Coffee: Consumption and Health Implications; Farah, A., Ed.; Royal Society of Chemistry: London, UK, 2019; ISBN 978-1782620044.

381. van Dijk, A.E.; Olthof, M.R.; Meeuse, J.C.; Seebus, E.; Heine, R.J.; van Dam, R.M. Acute effects of decaffeinated coffee and the major coffee components chlorogenic acid and trigonelline on glucose tolerance. Diabetes Care 2009, 32, 1023-1025. [CrossRef]

382. van Dieren, S.; Uiterwaal, C.S.; van der Schouw, Y.T.; van der, A.D.I.; Boer, J.M.; Spijkerman, A.; Grobbee, D.E.; Beulens, J.W. Coffee and tea consumption and risk of type 2 diabetes. Diabetologia 2009, 52, 2561-2569. [CrossRef]

383. Albrand, G.; Munoz, F.; Sornay-Rendu, E.; DuBoeuf, F.; Delmas, P.D. Independent predictors of all osteoporosis-related fractures in healthy postmenopausal women: The OFELY study. Bone 2003, 32, 78-85. [CrossRef]

384. Fung, T.T.; Arasaratnam, M.H.; Grodstein, F.; Katz, J.N.; Rosner, B.; Willett, W.C.; Feskanich, D. Soda consumption and risk of hip fractures in postmenopausal women in the Nurses' Health Study. Am. J. Clin. Nutr. 2014, 100, 953-958. [CrossRef] [PubMed]

385. Hallstrom, H.; Byberg, L.; Glynn, A.; Lemming, E.W.; Wolk, A.; Michaelsson, K. Long-term coffee consumption in relation to fracture risk and bone mineral density in women. Am. J. Epidemiol. 2013, 178, 898-909. [CrossRef] [PubMed]

386. Jha, R.M.; Mithal, A.; Malhotra, N.; Brown, E.M. Pilot case-control investigation of risk factors for hip fractures in the urban Indian population. BMC Musculoskelet. Disord. 2010, 11, 48. [CrossRef] [PubMed]

387. Lee, D.R.; Lee, J.; Rota, M.; Lee, J.; Ahn, H.S.; Park, S.M.; Shin, D. Coffee consumption and risk of fractures: A systematic review and dose-response meta-analysis. Bone 2014, 63, 20-28. [CrossRef] [PubMed]

388. Conlisk, A.J.; Galuska, D.A. Is caffeine associated with bone mineral density in young adult women? Prev. Med. 2000, 31, 562-568. [CrossRef] [PubMed]

389. Hannan, M.T.; Felson, D.T.; Dawson-Hughes, N.; Tucker, K.L.; Cupples, L.A.; Wilson, P.W.; Kiel, D.P. Risk factors for longitudinal bone loss in elderly men and women: The Framingham Osteoporosis Study. J. Bone Miner. Res. 2000, 15, 710-720. [CrossRef] [PubMed]

390. El Maghraoui, A.; Ghazi, M.; Gassim, S.; Ghozlani, I.; Mounach, A.; Rezqi, A.; Dehhaoui, M. Risk factors of osteoporosis in healthy Moroccan men. BMC Musculoskelet. Disord. 2010, 11, 148. [CrossRef] [PubMed]

391. Hallström, H.; Melhus, H.; Glynn, A.; Lind, L.; Syvänen, A.C.; Michaëlsson, K. Coffee consumption and CYP1A2 genotype in relation to bone mineral density of the proximal femur in elderly men and women: A cohort study. Nutr. Metab. 2010, 22, 7-12. [CrossRef] [PubMed] 
392. Harter, D.L.; Busnello, F.M.; Dibi, R.P.; Stein, A.T.; Kato, S.K.; Vanin, C.M.D.N. Association between low bone mass and calcium and caffeine intake among perimenopausal women in Southern Brazil: Cross-sectional study. São Paulo Med. J. 2013, 131, 315-322. [CrossRef] [PubMed]

393. Rapuri, P.B.; Gallagher, J.C.; Kinyamu, H.K.; Ryschon, K.L. Caffeine intake increases the rate of bone loss in elderly women and interacts with vitamin D receptor genotypes. Am. J. Clin. Nutr. 2001, 74, 694-700. [CrossRef] [PubMed]

394. Heaney, R.P.; Rafferty, K. Carbonated beverages and urinary calcium excretion. Am. J. Clin. Nutr. 2001, 74, 343-347. [CrossRef] [PubMed]

395. Ribeiro-Alves, M.; Trugo, L.C.; Donangelo, C.M. Use of oral contraceptives blunts the calciuric effect of caffeine in young adult women. J. Nutr. 2003, 133, 393-398. [CrossRef] [PubMed]

396. Hernández-Avila, M.; Colditz, G.A.; Stampfer, M.J.; Rosner, B.; Speizer, F.E.; Willet, W.C. Caffeine, moderate alcohol intake, and risk of fractures of the hip and forearm in middle-aged women. Am. J. Clin. Nutr. 1991, 54, 157-163. [CrossRef] [PubMed]

397. Hallstrom, H.; Wolk, A.; Glynn, A.; Michaëlsson, K. Coffee, tea and caffeine consumption in relation to osteoporotic fracture risk in a cohort of Swedish women. Osteoporos. Int. 2006, 17, 1055-1064. [CrossRef] [PubMed]

398. Heaney, R.P.; Recker, R.R. Effects of nitrogen, phosphorus, and caffeine on calcium balance in women. J. Lab. Clin. Med. 1982, 99, 46-55. [PubMed]

399. Barger-Lux, M.J.; Heaney, R.P.; Stegman, M.R. Effects of moderate caffeine intake on the calcium economy of premenopausal women. Am. J. Clin. Nutr. 1990, 52, 722-725. [CrossRef] [PubMed]

400. Hernández-Avila, M.; Stampfer, M.J.; Ravnikar, V.A.; Willet, W.C.; Schiff, I.; Francis, M.; Longscope, C.; McKinley, S.M. Caffeine and other predictors of bone density among pre- and perimenopausal women. Epidemiology 1993, 4, 128-134. [CrossRef] [PubMed]

401. Barger-Lux, M.J.; Heaney, R.P. Vitamin D receptor gene polymorphism, bone mass, body size, and vitamin D receptor density. Calcif. Tissue Int. 1995, 57, 161-162. [CrossRef]

402. Barbour, K.E.; Zmuda, J.M.; Strotmeyer, E.S.; Horwitz, M.J.; Boudreau, R.; Evans, R.W.; Ensrud, K.E.; Petit, M.A.; Gordon, C.L.; Cauley, J.A. Correlates of trabecular and cortical volumetric bone mineral density of the radius and tibia in older men: The Osteoporotic Fractures in Men Study. Bone Miner. Res. 2010, 25, 1017-1028. [CrossRef]

403. Hasling, C.; Søndergaard, K.; Charles, P.; Mosekilde, L. Calcium metabolism in postmenopausal osteoporotic women is determined by dietary calcium and coffee intake. J. Nutr. 1992, 122, 1119-1126. [CrossRef] [PubMed]

404. Gressner, O.A.; Lahme, B.; Siluschek, M.; Gressner, A.M. Identification of paraxanthine as the most potent caffeine-derived inhibitor of connective tissue growth factor expression in liver parenchymal cells. Liver Int. 2009, 29, 886-897. [CrossRef] [PubMed]

405. Fromigue, O.; Modrowski, D.; Marie, P.J. Growth factors and bone formation in osteoporosis: Roles for fibroblast growth factor and transforming growth factor beta. Curr. Pharma. Des. 2004, 10, 2593-2603. [CrossRef]

406. Evans, B.A.; Elford, C.; Pexa, A.; Francis, K.; Hughes, A.C.; Deussen, A.; Ham, J. Human osteoblast precursors produce extracellular adenosine, which modulates their secretion of IL-6 and osteoprotegerin. J. Bone Miner. Res. 2006, 21, 228-236. [CrossRef] [PubMed]

407. Dlugosz, L.; Bracken, M.B. Reproductive effects of caffeine: A review and theoretical analysis. Epidemiol. Rev. 1992, 14, 83-100. [CrossRef]

408. Golding, J. Reproduction and caffeine consumption-a literature review. Early Hum. Dev. 1995, 43, 1-14. [CrossRef]

409. Leviton, A. Does coffee consumption increase the risk of reproductive adversities? J. Am. Med. Womens Assoc. 1995, 50, 20-22.

410. Northstone, K.; Golding, J. Caffeine and Activation Theory Effects on Health and Behavior; Smith, B.D., Gupta, U., Gupta, B.S., Eds.; CRC Press: Boca Raton, FL, USA, 2007; p. 199.

411. Morgan, S.; Koren, G.; Bozzo, P. Is caffeine consumption safe during pregnancy? Can. Fam. Physician 2013, $59,361-362$. 
412. Peck, J.D.; Leviton, A.; Cowan, L.D. A review of the epidemiologic evidence concerning the reproductive health effects of caffeine consumption: A 2000-2009 update. Food Chem. Toxicol. 2010, 48, 2549-2576. [CrossRef]

413. Rondo, P.H.C.; Rodrigues, L.C.; Tomkins, A.M. Coffee consumption and intrauterine growth retardation in Brazil. Eur. J. Clin. Nutr. 1996, 50, 705-709.

414. Karen, G. Caffeine during pregnancy? In moderation. Can. Fam. Physician 2000, 46, 801-803.

415. Rosenberg, L.; Mitchell, A.A.; Shapiro, S.; Slone, D. Selected birth defects in relation to caffeine-containing beverages. J. Am. Med. Assoc. 1982, 247, 1429-1432. [CrossRef]

416. Olsen, J.; Overvad, K.; Frische, G. Coffee consumption, birthweight, and reproductive failures. Epidemiology 1991, 2, 370-374. [CrossRef] [PubMed]

417. Christian, M.S.; Brent, R.L. Teratogen update: Evaluation of the reproductive and developmental risks of caffeine. Teratology 2001, 64, 51-78. [CrossRef] [PubMed]

418. CARE Study Group. Maternal caffeine intake during pregnancy and risk of fetal growth restriction: A large prospective observational study. BMJ 2008, 337, 2332. [CrossRef] [PubMed]

419. Sengpiel, V.; Elind, E.; Bacelis, J.; Nilsson, S.; Grove, J.; Myhre, R.; Haugen, M.; Meltzer, H.M.; Alexander, J.; Jacobsson, B.; et al. Maternal caffeine intake during pregnancy is associated with birth weight but not with gestational length: Results from a large prospective observational cohort study. BMC Med. 2013, 11, 42. [CrossRef] [PubMed]

420. Bross, I.D.J.; Tidings, J. Another look at coffee drinking and cancer of the urinary bladder. Prev. Med. 1973, 2, 445-451. [CrossRef]

421. Bravo, P.; deI Rey, J.; Sánchez, J.; Conde, M. Coffee and analgesics as risk factors for cancer of the bladder. Arch. Esp. Urol. 1986, 39, 337-341.

422. Ciccne, G.; Vineis, P. Coffee drinking and bladder cancer. Cancer Lett. 1988, 41, 45-52. [CrossRef]

423. International Agency for Research on Cancer-IARC Working Group. IARC Monographs on the Evaluation of Carcinogenic Risks to Humans: Coffee, Tea, Maté, Methylxanthines and Methylglyoxal; IARC Working Group: Lyon, France, 1991.

424. Botelho, F.; Lunet, N.; Barros, H. Coffee and gastric cancer: Systematic review and meta-analysis. Cad. Saúde Públ. 2006, 22, 889-900. [CrossRef]

425. Lee, J.E.; Hunter, D.J.; Spiegelman, D.; Adami, H.O.; Bernstein, L.; van den Brandt, P.A.; Buring, J.E.; Cho, E.; English, D.; Folsom, A.R.; et al. Intakes of coffee, tea, milk, soda and juice and renal cell cancer in a pooled analysis of 13 prospective studies. Int. J. Cancer 2007, 121, 2246-2253. [CrossRef] [PubMed]

426. Boggs, D.A.; Palmer, J.R.; Stampfer, M.J.; Spiegelman, D.; Adams-Campbell, L.L.; Rosenberg, L. Tea and coffee intake in relation to risk of breast cancer in the Black Women's Health Study. Cancer Causes Control 2010, 21, 1941-1948. [CrossRef] [PubMed]

427. Fagherazzi, G.; Touillaud, M.S.; Boutron-Ruault, M.C.; Clavel-Chapelon, F.; Romieu, I. No association between coffee, tea or caffeine consumption and breast cancer risk in a prospective cohort study. Public Health Nutr. 2011, 5, 1315-1320. [CrossRef] [PubMed]

428. Giovannucci, E. Meta-analysis of coffee consumption and risk of colorectal cancer. Am. J. Epidemiol. 1998, 147, 1043-1052. [CrossRef]

429. Naganuma, T.; Kuriyama, S.; Akhter, M.; Kakizaki, M.; Nakaya, N.; Matsuda-Ohmori, K. Coffee consumption and the risk of colorectal cancer: A prospective cohort study in Japan. Int. J. Cancer 2007, 120, 1542-1547. [CrossRef] [PubMed]

430. Yu, X.; Zou, Z.J.; Dong, J. Coffee consumption and risk of cancers: A meta-analysis of cohort studies. BMC Cancer 2011, 11, 96. [CrossRef] [PubMed]

431. Wang, A.; Wang, S.; Zhu, C.; Huang, H.; Wu, L.; Wan, X.; Yang, X.; Zhang, H.; Miao, R.; He, L.; et al. Coffee and cancer risk: A meta-analysis of prospective observational studies. Sci. Rep. 2016, 6, 33711. [CrossRef] [PubMed]

432. Strain, E.; Mumford, G.; Silverman, K.; Griffiths, R.R. Caffeine dependence syndrome. Evidence from case histories and experimental evaluations. JAMA 1994, 272, 1043-1048. [CrossRef] [PubMed]

433. Silverman, K.; Evans, S.M.; Strain, E.C.; Griffiths, R.R. Withdrawal syndrome after the double-blind cessation of caffeine consumption. N. Engl. J. Med. 1992, 327, 1109-1114. [CrossRef] [PubMed]

434. American Psychiatric Association. Diagnostic and Statistical Manual of Mental Disorders; American Psychiatric Association: Washington, DC, USA, 1994. 
435. Evans, S.M.; Griffiths, R.R. Caffeine withdrawal: A parametric analysis of caffeine dosing conditions. J. Pharm. Exp. Ther. 1999, 289, 285-294.

436. Phillips-Bute, B.G.; Lane, J.D. Caffeine withdrawal symptoms following brief caffeine deprivation. Physiol. Behav. 1998, 63, 35-39. [CrossRef]

437. Höfer, I.F.; Bättig, K. Psychophysiological effects of switching to caffeine tablets or decaffeinated coffee under field conditions. Pharmacopsychoecologia 1994, 7, 169-177.

438. Griffiths, R.R.; Bigelow, G.E.; Liebson, I.A. Human coffee drinking: Reinforcing and physical dependence producing effects of caffeine. J. Pharmacol. Exp. Ther. 1986, 239, 416-425. [PubMed]

439. Lader, M.; Cardwell, C.; Shine, P.; Scott, N. Caffeine withdrawal symptoms and rate of metabolism. J. Psychopharmacol. 1996, 10, 110-118. [CrossRef] [PubMed]

440. McGowan, J.D.; Altman, R.E.; Kanto, W.P., Jr. Neonatal withdrawal symptoms after chronic maternal ingestion of caffeine. South. Med. J. 1988, 81, 1092-1094. [CrossRef]

441. Goldstein, A.; Wallace, M.E. Caffeine dependence in schoolchildren? Exp. Clin. Psychopharmacol. 1997, 5, 388-392. [CrossRef]

442. Pallarés, J.G.; Fernández-Elías, V.E.; Ortega, J.F.; Muñoz, G.; Muñoz-Guerra, J.; Mora Rodríguez, R. Neuromuscular responses to incremental caffeine doses: Performance and side effects. Med. Sci. Sports Exerc. 2013, 45, 2184-2192. [CrossRef]

443. Nardi, A.E.; Lopes, F.L.; Freire, R.C.; Veras, A.B.; Nascimento, I.; Valença, A.M.; de-Melo Neto, V.L.; Soares-Filho, G.L.; King, A.L.; Araújo, D.M.; et al. Panic disorder and social anxiety disorder subtypes in a caffeine challenge test. Psychiatry Res. 2009, 169, 149-153. [CrossRef] [PubMed]

444. Mesas, A.E.; Leon-Munoz, L.M.; Rodriguez-Artalejoand, F.; Lopez-Garcia, E. The effect of coffee on blood pressure and cardiovascular disease in hypertensive individuals: A systematic review and meta-analysis. Am. J. Clin. Nutr. 2011, 94, 1113-1126. [CrossRef]

445. Noordzij, M.; Uiterwaal, C.; Arends, L.; Kok, F.; Grobbee, D.; Geleijnse, J. Blood pressure response to chronic intake of coffee and caffeine: A meta-analysis of randomized controlled trials. J. Hypertens. 2005, 23, 921-992. [CrossRef]

446. Shi, X.; Xue, W.; Liang, S.; Zhao, J. Acute caffeine ingestion reduces insulin sensitivity in healthy subjects: A systematic review and meta-analysis. Nutr. J. 2016, 15, 103. [CrossRef] [PubMed]

447. Whitehead, N.; White, H. Systematic review of randomized controlled trials of the effects of caffeine or caffeinated drinks on blood glucose concentrations and insulin sensitivity in people with diabetes mellitus. J. Hum. Nutr. Diet. 2013, 26, 111-125. [CrossRef]

448. Harris, S.S.; Dawson-Hughes, B. Caffeine and bone loss in healthy postmenopausal women. Am. J. Clin. Nutr. 1994, 60, 573-578. [CrossRef] [PubMed]

449. Lyngsø, J.; Ramlau-Hansen, C.H.; Bay, B.; Ingerslev, H.J.; Hulman, A.; Kesmodel, U.S. Association between coffee or caffeine consumption and fecundity and fertility: A systematic review and dose-response meta-analysis. Clin. Epidemiol. 2017, 9, 699-719. [CrossRef]

450. Vaseghi, G.; Haghjoo-Javanmard, S.; Naderi, J.; Eshraghi, A.; Mahdavi, M.; Mansourian, M. Coffee consumption and risk of nonmelanoma skin cancer: A dose-response meta-analysis. Eur. J. Cancer Prev. 2018, 27, 164-170. [CrossRef]

451. Liu, J.; Shen, B.; Shi, M.; Cai, J. Higher caffeinated coffee intake is associated with reduced malignant melanoma risk: A meta-analysis study. PLoS ONE 2016, 11, e0147056. [CrossRef]

452. New Zealand Ministry of Health. Nutrient Reference Values for Australia and New Zealand Including Recommended Dietary Intakes; New Zealand Ministry of Health: Wellington, New Zealand, 2006.

453. Higdon, J.V.; Frei, B. Coffee and health: A review of recent human research. Crit. Rev. Food Sci. Nutr. 2006, 46, 101-123. [CrossRef]

454. Yang, A.; Palmer, A.A.; de Wit, H. Genetics of caffeine consumption and responses to caffeine. Psychopharmacology 2010, 211, 245-257. [CrossRef] [PubMed]

455. Caffeine Informer. Available online: https://www.caffeineinformer.com (accessed on 9 February 2019).

456. Aepli, A.; Kurth, S.; Tesler, N.; Jenni, O.G.; Huber, R. Caffeine consuming children and adolescents show altered sleep behavior and deep sleep. Brain Sci. 2015, 5, 441-455. [CrossRef] [PubMed]

457. Cunha, R.A.; Ferré, S.; Vaugeois, J.M.; Chen, J.-F. Potential therapeutic interest of adenosine A2A receptors in psychiatric disorders. Curr. Pharm. Des. 2008, 14, 1512-1524. [CrossRef] [PubMed] 
458. Garfinkel, B.D.; Webster, C.D.; Sloman, L. Responses to methylphenidate and varied doses of caffeine in children with attention deficit disorder. Can. J. Psychiatry 1981, 26, 395-401. [CrossRef] [PubMed]

459. Castellanos, F.X.; Rapoport, J.L. Effects of caffeine on development and behavior in infancy and childhood: A review of the published literature. Food Chem. Toxicol. 2002, 40, 1235-1242. [CrossRef]

460. ABIC-Associação Brasileira das Indústrias de Café. Available online: http://www.abic.com.br (accessed on 9 February 2019).

461. American Academy of Pediatrics; Adolescent Sleep Working Group; Committee on Adolescence; Council on School Health. School start times for adolescents. Pediatrics 2014, 134, 642-649. [CrossRef] [PubMed]

462. Health Canada. It's Your Health-Caffeine. Available online: http://www.hc-sc.gc.ca/hlvs/iyh-vsv/foodaliment/caffeine-eng.php (accessed on 9 February 2019).

463. Korea Food and Drug Administration. Korea Nutrition Society; Korea Food and Drug Administration: Seoul, Korea, 2006.

464. International Life Sciences Institute-ILSI. Food Safety - Caffeine; ILSI: Washington, DC, USA, 2010.

465. United Kingdom Food Stand Agency. The Safety Aspects of Dietary Caffeine; Ministry of Heath: London, UK.

466. Knight, C.A.; Knight, I.; Mitchell, D.C. Beverage caffeine intakes in young children in Canada and the US. J. Diet. Prac. Res. 2006, 67, 96-99. [CrossRef] [PubMed]

(C) 2019 by the authors. Licensee MDPI, Basel, Switzerland. This article is an open access article distributed under the terms and conditions of the Creative Commons Attribution (CC BY) license (http://creativecommons.org/licenses/by/4.0/). 